ANL-7329

ANL-7329

O

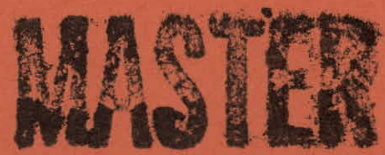

Argonne Дational Laboratom

REACTOR DEVELOPMENT PROGRAM

PROGRESS REPORT

April 1967 


\section{DISCLAIMER}

This report was prepared as an account of work sponsored by an agency of the United States Government. Neither the United States Government nor any agency Thereof, nor any of their employees, makes any warranty, express or implied, or assumes any legal liability or responsibility for the accuracy, completeness, or usefulness of any information, apparatus, product, or process disclosed, or represents that its use would not infringe privately owned rights. Reference herein to any specific commercial product, process, or service by trade name, trademark, manufacturer, or otherwise does not necessarily constitute or imply its endorsement, recommendation, or favoring by the United States Government or any agency thereof. The views and opinions of authors expressed herein do not necessarily state or reflect those of the United States Government or any agency thereof. 


\section{DISCLAIMER}

Portions of this document may be illegible in electronic image products. Images are produced from the best available original document. 
The facilities of Argonne National Laboratory are owned by the United States Government. Under the terms of a contract (W-31-109-Eng-38) between the U. S. Atomic Energy Commission, Argonne Universities Association and The University of Chicago, the University employs the staff and operates the Laboratory in accordance with policies and programs formulated, approved and reviewed by the Association.

\section{MEMBERS OF ARGONNE UNIVERSITIES ASSOCIATION}

The University of Arizona Carnegie Institute of Technology Case Institute of Technology The University of Chicago University of Cincinnati Illinois Institute of Technology Iniversity of Illinnis Indiana University Iowa State University
The University of Iowa Kansas State University The University of Kansas Loyola University Marquette University Michigan State University The IIniversity of Mirhigan University of Minnesota University of Missouri
Northwestern University University of Notre Dame The Ohio State University Purdue University Saint Louis University Washington University Wayne State IIniversity The University of Wisconsin

\section{LEGAL NOTICE}

This report was prepared as an account of Government sponsored work. Neither the United States, nor the Commission, nor any person acting on behalf of the Commission:

A. Makes any warranty or representation, expressed or implied, with respect to the accuracy, completeness, or usefulness of the information contained in this report, or that the use of any information, apparatus, method, or process disclosed in this report may not infringe privately owned rights; or

B. Assumes any liabilities with respect to the use of, or for damages resulting from the use of any information, apparatus, method, or process disclosed in this report.

As used in the above, "person acting on behalf of the Commission" includes any employee or contractor of the Commission, or employee of such contractor, to the extent that such employee or contractor of the Commission, or employee of such contractor prepares, disseminates, or provides access to, any information pursuant to his employment or contract with the Commission, or his employment with such contractor.

Printed in the United States of America Available from

Clearinghouse for Federal Scientific and Technical Information

National Bureau of Standards, U. S. Department of Commerce

Springfield, Virginia 22151

Price: Printed Copy $\$ 3.00 ;$ Microfiche $\$ 0.65$ 


\author{
ARGONNE NATIONAL LABORATORY \\ 9700 South Cass Avenue \\ Argonne, Illinois 60439
}

\title{
GRER RCAS
}

H. $3.00 . \max 65$

\section{REACTOR DEVELOPMENT PROGRAM PROGRESS REPORT}

April 1967

Albert V. Crewe, Laboratory Director

Stephen Lawroski, Associate Laboratory Director

\author{
Division \\ Chemical Engineering \\ Idaho \\ Metallurgy \\ Reactor Engineering \\ Reactor Physics \\ Remote Control
}

\section{Director}

R. C. Vógél

M. Novick

M. V. Nevitt

L. J. Koch

R. Avery

D. P. Mingesz (Acting)

Report coordinated by

R. M. Adams and A. Glassner

Is sued June 16,1967

\footnotetext{
LEGAL NOTICE

This report was prepared as an account of Government gponsored work. Nelther the United Sta

A. Makes any warranty or representation, expressed or implied, with respect to the accuA. Makes any warranty or representation, expressed or implied, with respect to the accuracy, completeness, or usefulness of the information contained in this report, or that the use privately owned rights; or

B. Assumes any liabilities with respect to the use of, or for damages resulting from the ef any information, apparatus, method, or process disclosed in this report.

As used in the above. "person acting on behalf of the Commission" includes any employee or contractor of the Commisaion, or employee of such contractor, to the extent that ployee or conto of such contractor prepares, diten disseminates, or provides access w. any intorm such contractor. 


\section{FOREWORD}

The Reactor Development Program Progress Report, issued monthly, is intended to be a means of reporting those items of:significant technical progress which have occurred in both the specific reactor projects and the general engineering research and development programs. The report is organized in a way which, it is hoped, gives the clearest, most logical overall view of progress. The budget classification is followed only in broad outline, and no attempt is made to report separately on each sub-activity number. Further, since the intent is to report only items of significant progress, not all activities are reported each month. In order to is sue this report as soon as possible after the end of the month editorial work must necessarily be limited. Also, since this is an informal progress report; the results and data presented should be understood to be preliminary and subject to change unless otherwise stated.

The issuance of these reports is not intended to constitute publication in any sense of the word. Final results either will be submitted for publication in regular professional journals or will be published in the form of ANL topical reports.

The last six reports issued in this series are:

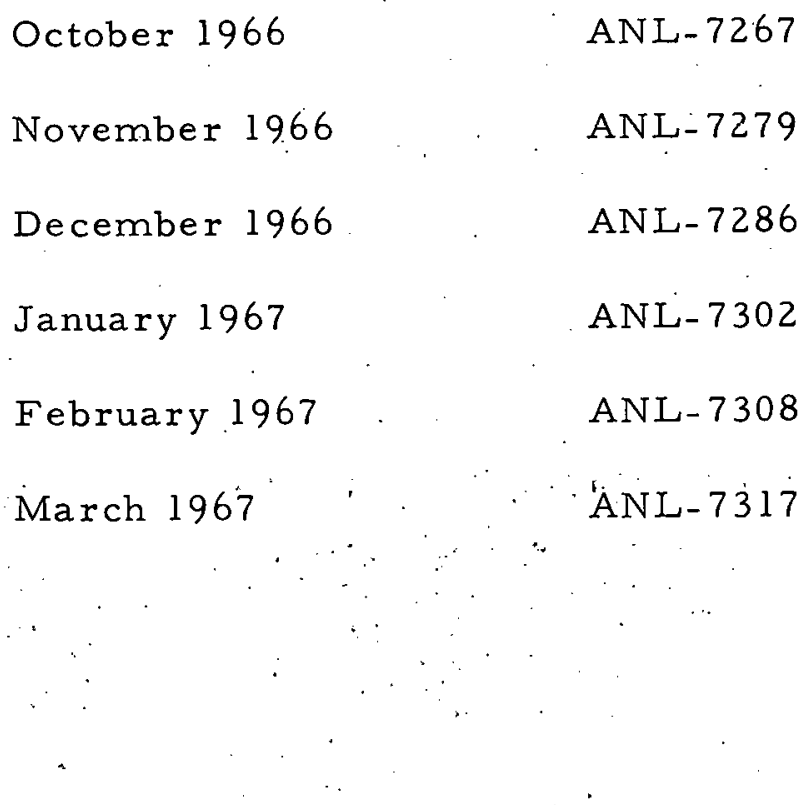


REACTOR DEVELOPMENT PROGRAM

Highlights of Project Activities for April 1967

EBWR Plutonium Recycle

EBWR has been operating at $70 \mathrm{MW}$ since the middle of March. The reactor was shut down on April 29 th so that special and normal plutonium fuel pins could be removed from the reactor for subsequent isotopic analysis at Pacific Northwest Laboratory. At the time of shutdown, the average exposure of the plutonium fuel was approximately $2400 \mathrm{MWd} /$ tonne. After shutdown, the reactor will be operated at $70 \mathrm{MW}$ until the next shutdown scheduled for July 1.

EBR - II

An intensive program of sodium sampling to determine the concentration of copper in sodium continued. Sampling upstream and downstream of the cold trap' showed that the average copper content on the effluent side of the cold trap was smaller than in the bulk sodium.

With receipt of AEC approval for power operation, Run No. 25 was begun on April 21, following several days of zero-power operation for kinetics measurements. Because of the replacement of depleted uranium with stainless steel subassemblies in Rows 7 and 8 , an extremely cautious approach-to-power program was initiated. Upon reaching $22 \mathrm{MWt}$, the observed decreasing power coefficient averaged $1 \mathrm{Ih} / \mathrm{MWt}$, an operating limit of the reactor. Accordingly, the reactor was shut down and then recycled through several power operations from 0 to $45 \mathrm{MWt}$ in small increments while closely monitoring the power coefficient at each step increment. At month's end, rod-drop data taken at all increments showed a consistent prompt negative power coefficient.

Nineteen additional blanket rods were removed from Rows $6,7,8$, and 10 of the reactor for dimensional and density measurements.

Work is progressing on installation of components for the cold fabrication addition to the Fuel Cycle Facility. Building of the injectioncasting equipment and design of the final assembly machine are $50 \%$ completed; pin processing and element-processing units are $75 \%$ completed. The Laboratory's recommendations for selection of an outside vendor for driver fuel have been submitted to AEC.

Sixteen subassemblies were fabricated this month. 
Assembly 49, the second of a planned series of plutonium cores with well-degraded spectra has been loaded into the reactor. The uncorrected critical mass for this assembly is $282 \mathrm{~kg}$ plutonium. Fuel-drawer worths at the edge and control- and safety-rod measurements are under way to provide data for critical-mass corrections. Analyses of data from

Assemblies 48 and $48 \mathrm{~A}$ (the latter in support of the FFTF program) are presented this month.

ZPPR

A significant amount of concrete pouring was accompiished this month; the reactor cell wall has been placed up to the lower ring beam, the roof of the fuel-storage vault-workroom area was poured, and the west wall of the support wing has been placed. Placement of backfill and interior work on finishing of walls, installation of ventilating ducts, etc., is in progress. The reactor bed and tables are now protected in on-site storage by an impact shield. The Final Safety Analysis Report is nearing completion.

AARR

The primary-pump proposals have been received and the reactorvessel contract has been negotiated and is awaiting AEC approval.

Detail design of the beam-tube test facility has been completed. 
A. Operations 1

II. LIQUID-METAL FAST BREEDER REACTORS 2

A. EBR-II 2

1. Operations - 2

2. Copper in Primary Sodium 4

3. EBR-II Driver. Fuel Development and Metallurgical Assistance

4. Reactor Improvements 8

5. Surveillance . 14

6. Experimental Irradiations 15

7. Vertical Assembler-Disassembler (VAD) 18

8. Fuel Cycle Facility (FCF) 18

B. Physics Development 21

1. ZPR-3 2.1

2. $Z P R-6$. 25

3. ZPR-9 33

4. ZPPR 33

5. Plutonium Fuel Procurement 35

C. Other Fast Reactor Physics $\quad 37$

1. Plutonium Air Monitor for Use in ZPR Areas 37

D. Component Development 37

1. Sodium Technology and Development 37

2. Liquid Sodium Coolant Chemistry 41

E. Fuel Development $\quad 42$

1. Metal Fuels 42

2. Carbide Fuels 43

3. Fuel Cladding and Structure 48

4. Fuel Reprocessing 51 
F. Design Concept Analysis and Advanced Systems Evaluation

1. 1000-MWe Study

G. General Research and Development

1. Fast Reactor Core-parameter Study

A. Applied and Reactor Physics Development

1. An Improved Diagnostic Technique for Input-Output Equipment

2. The ARC System.

3. Cross-section Evaluations

B. Reactor Fuels and Materials Development

1. Chemistry of Fuel Materials

2. Fabrication and Evaluation

3. Techniques of Fabrication and Testing

C. Engineering Development

1. Development of Master-Slave Manipulator Systems

2. Heat Transfer and Fluid Flow

3. Mechanics of Materials

D. Chemistry and Chemical Separations

1. Fluoride Volatility Processes

A. Argonne Advanced Research Reactor (AARR) 75

1. General , 75

2. Containment Potential of the Primary Coolant System 75

3. Instrumentation and Control--Flow-coastdown: Dynamics 
4. Component Development " $\quad 82$

5. Core Development $\quad \therefore \quad 83$

V. NUCLEAR SAFETY . . . . $\quad 87$

$\begin{array}{ll}\text { A. Coolant Dynamics } & 87\end{array}$

1. Sodium Expulsion $\quad 87$

2. Superheat $\quad 87$

3. Critical Flow. 87

4. Electron-bombardment Heater Tests 89

5. Convective Instability : 89

6. Thermophysical Properties of Sodium 90

B. Fuel Meltdown Studies with TREAT 90

1. Reactivity Measurements for Large Loop and Testsection Mockup 90

2. Unbonded EBR-II Pin in Flowing Sodium 92

3. Power Supply for High-temperature Furnace Operation

4. Glovebox for Low-level Beta-Gamma TREAT Samples Containing Plutonium

C. TREAT Operations 93

D. Chemical and Associated Energy Problems (Thermal) 94

1. Laboratory Studies with Zircaloy-2-clad, $\mathrm{UO}_{2}$-core Fuel Rods Simulating the Conditions of a Loss-ofcoolant Accident

E. Safeguard Technology--Containment

1. Primary Containment by Energy Absorption for Water Reactors

F. Plutonium Volatility Safety

1. Chemistry of Tellurium Fluorides 99 


\section{.I. PLUTONIUM UTILIZATION--EBWR}

\section{A. Operations}

After two months of operation at $70 \mathrm{MWt}$ (5. MWe), the EBWR facility was shut down on April 29, 1967. This completed the second irradiation step. At the time of shutdown, the average exposure of the plutonium fuel was approximately $2400 \mathrm{MWd} /$ tonne. Seventeen fuel pins will be removed from the southwest quadrant of the plutonium zone. One set of plutonium foils will be changed in the plutonium zone and a set placed in the enriched zone. The pins removed at the completion of the first irradiation step (see Progress Report for February 1967, ANL-7308, p. 1) will be removed from the EBWR containment shell for transfer to Battelle Northwest Laboratory.

On April 27, the turbine was taken off line due to a sudden. increase in the vibration magnitude. As an external cause could not be found, the top turbine casing will be removed during the shutdown to locate and, hopefully, repair the cause. This will lengthen the shutdown schedule by approximately one week. Power operations are expected to resume by mid-May 1967.

The power generated.by the plant was as follows:

$\begin{array}{cr}\frac{\text { Thermal Power }}{48,182.1 \mathrm{MWh}} & \frac{\text { Electrical Power }}{3,802.0 \mathrm{MWh}} \\ 165,533.9 \mathrm{MWh} & 16,671.0 \mathrm{MWh}\end{array}$

Recycle Program

$165,533.9 \mathrm{MWh}$

$16,671.0 \mathrm{MWh}$ 


\title{
II. LIQUID-METAL FAST BREEDER REACTORS
}

\author{
A. EBR-II
}

\section{Operations}

An intensive sodium-sampling program continued during the month (see Sect. II.A.2) to determine the extent of copper dissolution in the primary sodium system and to ascertain the effect of cold trapping on reducing this copper content (see Progress Report for March 1967, ANL-7317, pp. 1-7). The concentration of copper in the primary sodium averaged about $1.18 \mathrm{ppm}$ for all samples, and cold trapping for about a month has not produced a noticeable change in this value. However, the data taken on samples from the effluent side of the cold trap showed a smaller average concentration of copper than did the bulk sodium, about 0.69 ppm copper for all samples taken.

Inspection of photographs taken of the primary auxiliary pump negative bus bar when it was removed from the reactor in March showed what appeared to be either a.scratch or a crack. The bus bar was again removed and inspection showed that only a shallow scratch mark was present on the bus bar sheath. The scratch was buffed out and the bus bar was replaced on. April 7.

All outer-blanket uranium subassemblies in Row 8 were replaced with stainless steel subassemblies and the required adjustments of fuel loading were made in preparation for Run No. 25. Because of the indication from the primary-tank cover-gas chromatograph that nitrogen content had built up in excess of $20,000 \mathrm{ppm}$, the cover gas was purged with argon to bring the nitrogen content down to less than $5000 \mathrm{ppm}$. The reactor was operated on April 19 for zero-power kinetics measurements related to the loading for Run No. 25. These included control-rod drops using the stainless steel control rod, trapezoidal oscillations from movement of a control rod, and period calibration of all control rods.

Approval for operation:was received from AEC late on. April 20 and the reactor was started up for power operation the next day. Because of loading changes made since the last run, the schedule for approach to power was extremely cautious. It was necessary, for example, to recalibrate the nuclear detectors because of the change in leakage flux resulting from the loading changes: this was done using the thermal. output of the reactor as a reference. Measurements of power coefficient and kinetic performance of the reactor were made at small increments of increasing power.

At low powers the power coefficient was normal; however, its value decreased with increasing power until at about $22 \mathrm{MWt}$ the overall power 
coefficient averaged $1 \mathrm{Ih} / \mathrm{MW}$. Since this is one of the operating limits of the reactor, operation was suspended and a temporary waiver to the limit for the duration of the startup experiments was requested and obtained.

On April 24, the reactor was restarted, taking small, incrememtal power steps of $2.5 \mathrm{MW}$ to determine precisely the power coefficients and to take rod-drop measurements at 10,20 , and $25 \mathrm{MW}$ to determine the magnitude and sign of the prompt power coefficient. The reactivity data on this second run agreed well with that observed on the initial Run No. 25, and AEC approval was given to proceed above $25 \mathrm{MW}$ on the basis that continued surveillance of the incremental power coefficients and the results from roddrop tests assured a negative power coefficient and a prompt negative feedback.

The is othermal temperature coefficient of reactivity was established by noting changes in control-rod position at $50 \mathrm{~kW}$ when the bulk sodium temperature was reduced from 700 to. $650^{\circ} \mathrm{F}$. The data gave a value of. $1.04 \mathrm{Ih} /{ }^{\circ} \mathrm{F}$, quite close to the value of $1.01 \mathrm{Ih} /{ }^{\circ} \mathrm{F}$ established for earlier. loadings.

Subsequently, the reactor was recycled through two additional power operations from 0 to $45 \mathrm{MW}$, and data were taken at 37.5 and $45 \mathrm{MW}$ to determine overall and incremental power coefficients. Results are given in Table I. It will be noted that the magnitude of the power coefficient in the

TABLE I. EBR-II Power Coefficient--Run No: 25

\begin{tabular}{|c|c|c|c|c|c|c|c|}
\hline Power $(M W)^{a}$ & . & $\begin{array}{l}\Delta \mathrm{k} / \mathrm{k} \\
(\mathrm{Ih})^{\mathrm{a}}\end{array}$ & $\begin{array}{l}\left(\frac{\Delta \mathrm{k} / \mathrm{k}}{\mathrm{MW}}\right) \text { Overall } \\
\text { Average (Ih/MW) }\end{array}$ & . & $\left(\frac{\Delta \mathrm{k} / \mathrm{k}}{\Delta \mathrm{MW}}\right)$ & $\begin{array}{l}\text { Increm } \\
(\mathrm{Ih} / \mathrm{MW})\end{array}$ & ental \\
\hline 0 & & 0 & & & & & \\
\hline 10.0 & & 16.2 & 1.62 & & & 1.62 & \\
\hline 12.5 & & 18.2 & 1.46 & & $\cdot$ & 0.80 & \\
\hline 15.0 & & 19.6 & 1.31 & & & 0.56 & \\
\hline 17.5 & & 21.0 & 1.20 & & & 0.56 & \\
\hline 20.5 & & 22.5 & 1.10 & & & $0: 50$ & \\
\hline 22.5 & & 23.6 & 1.05 & - & & 0.55 & \\
\hline 25.0 & & 24.8 & 0.99 & & & 0.48 & \\
\hline 28.0 & & 27.0 & 0.96 & & & 0.88 & \\
\hline 30.5 & & 28.3 & 0.93 & & & 0.52 & \\
\hline 33.0 & : & 29.6 & 0.90 & & & 0.52 & \\
\hline 36.0 & & 30.0 & 0.89 & & & 0.80 & \\
\hline 37.5 & $\cdot$ & 34.5 & 0.92 & & & 1.00 & \\
\hline .40 .0 & & 37.0 & 0.93 & & & 1.00 & \\
\hline 42.5 & & 40.2 & 0.95 & & & 1.28 & \\
\hline 45.0 & & 43.2 & 0.96 & & & 1.20 & \\
\hline \multicolumn{8}{|l|}{ Repeat 1} \\
\hline 37.5 & & 30.3 & 0.81 & . & & & \\
\hline $45.0^{\prime}$ & . & 38.4 & 0.85 & & & 1.08 & \\
\hline \multicolumn{8}{|l|}{ Repeat 2} \\
\hline .37 .5 & & 31.0 & 0.83 & & & & \\
\hline 45.0 & & 39.0 & 0.87 & & & 1.07 & \\
\hline
\end{tabular}

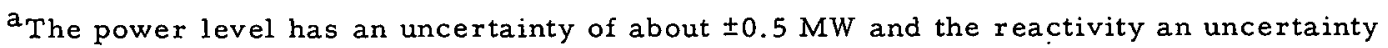
of \pm 0.5 Ih. 
two repeat runs is smaller than that of the first run, which may be due to a slight, permanent deformation of the core.

The significant difference between these last two sets of powercoefficient data and those previously taken is postulated to be due to the different heating effects and bowing characteristics of the new stainless steel reflector subassemblies in Rows 7 and 8 as compared to the previous uranium-containing subassemblies. Separating out the effects will require considerable analysis and carefully designed kinetics experiments.

By month's end, rod-drop data taken at 10,20,25,30,35,40, and $45 \mathrm{MW}$ all showed the existence of the usual prompt negative power coefficient.

\section{Copper in Primary Sodium}

The sampling system previously described (see Progress Report for March 1967, ANL-7317, pp. 4-7) was utilized for intensive sampling of the primary cold trap influent and effluent until late on April 3. Sampling of bulk sodium through the Fuel Transfer Port (FTP) was continued, also. The chemical analyses for copper are presented in Table II.

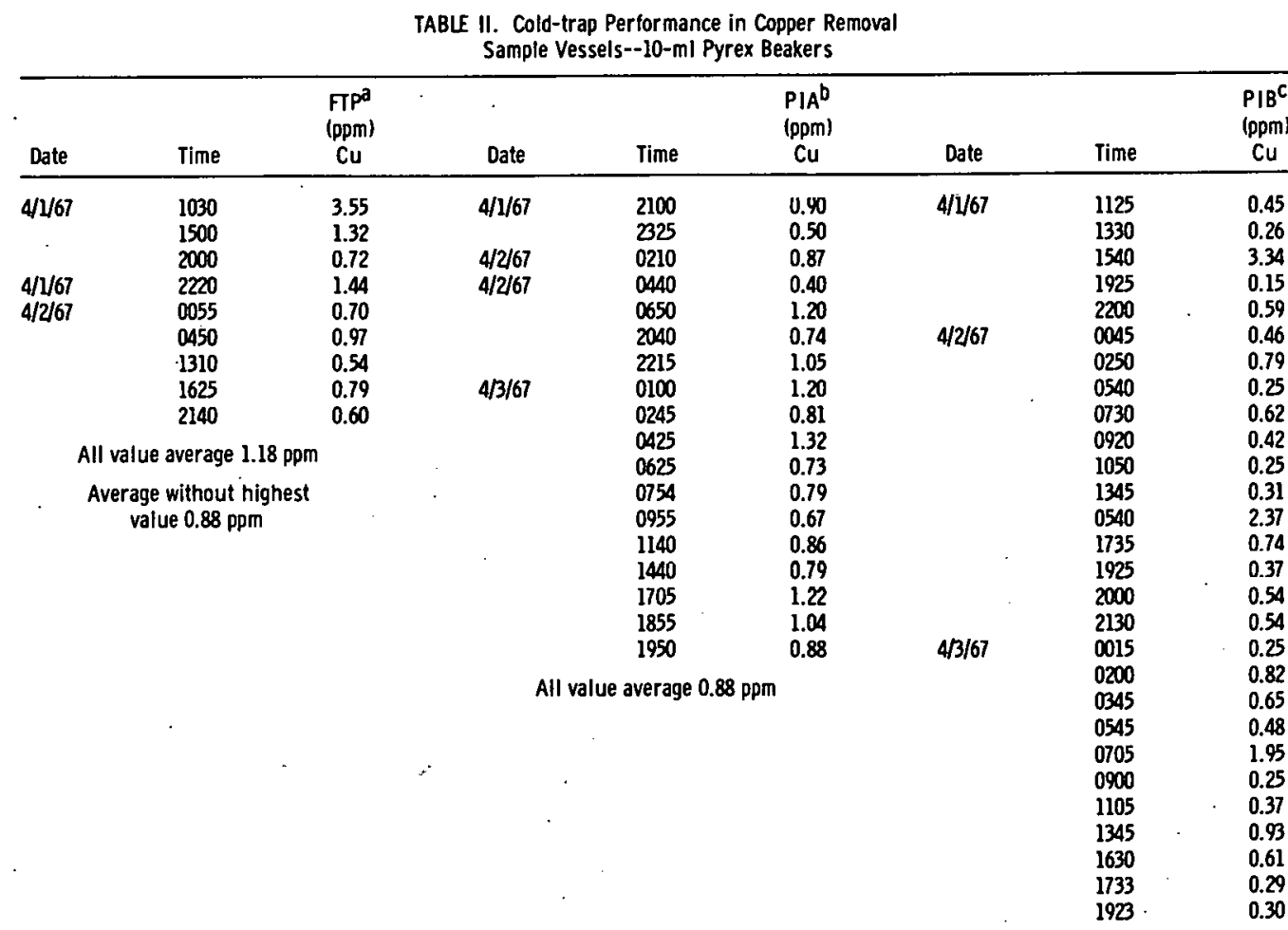


To give a better weighting of data than that given only by samples taken after April 1, 1967, nineteen values preceding this date at 1030 for the FTP and ten values preceding this date at 2100 for cold-trap effluent (PIA) were added to make up Table III. It might be argued that this treatment is not valid due to the time lapse between samples. However, over the entire period of sampling, no trends up or down were detectable, in-. dicating, for the period shown in the table, that there are no time-dependent concentration variations.

TABLE III: Weighted Copper Data

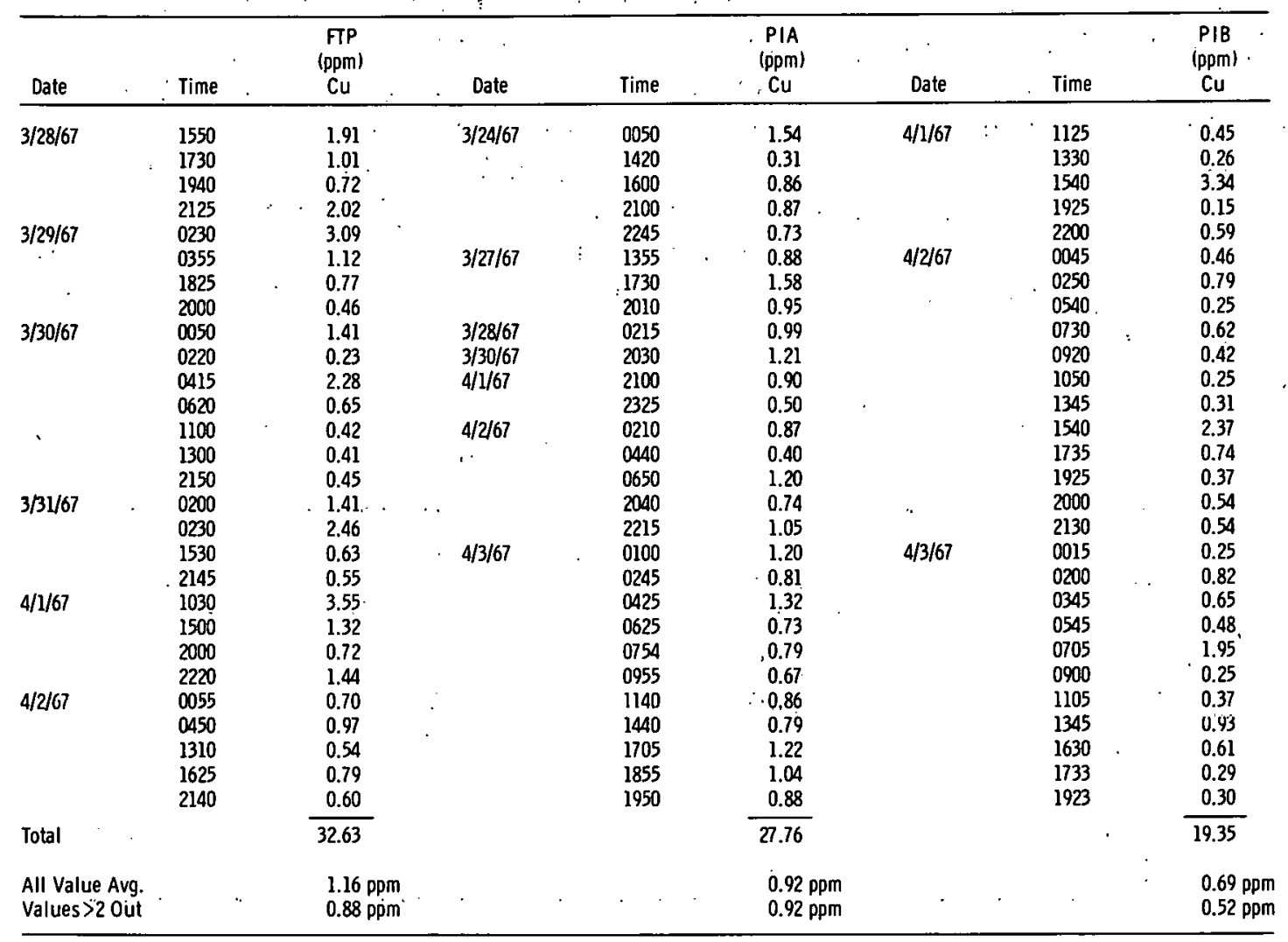

The results of averaging the data in Table II allow one to believe the cold trap is removing copper from the sodium. Table III, showing 28 values for each of the three points, reinforces this conclusion.

In preparing Table III, two very high values (24.25 and 9.95) for the FTP were discarded. We believe that this is justified because a relatively high copper concentration was found in a sample of sodium and sodium oxide scraped from the surfaces of the gripper guide tube in the fueltransfer port. Even though the dip sampler used for taking samples of bulk primary sodium through the FTP was designed so as to minimize the possibility of sample contamination, complete assurance cannot be given that contamination did not occur. 
The above-mentioned sample of scrapings was found to contain 39 ppm of copper. It is suspected that this copper may have been carried, as minute copper oxide particles, from the copper mesh packing of the gas purifier in the Fuel Unloading Machine (FUM) argon system. Consideration is being given to removal of the gas purifier, thus eliminating potential copper contribution from this source.

The equipment for sampling the primary sodium was modified for radioactive service. This work was completed on April 10, except for the installation of lead shielding, which was deferred pending checkout of the equipment. This sampling equipment is an adaptation, for radioactive service, of that used earlier for the intensive sampling of cold-trap influent and effluent. Samples can be taken in 10-ml Pyrex beakers from either the PI-A (cold-trap influent) or the PI-B (cold-trap effluent) sampling point. Sodium samples were taken from each sampling point on April 12 and 13 for checkout of the sampling system. Operation was satisfactory and, therefore, installation of shielding was completed. The samples were analyzed for copper content, with the results given in Table IV.

TABLE IV. Copper Analyses of Cold-trap Influent and Effluent

\begin{tabular}{lccc}
\hline Date & Time & $\begin{array}{c}\text { Sample } \\
\text { Point }\end{array}$ & $\begin{array}{c}\mathrm{Cu} \\
(\mathrm{ppm})\end{array}$ \\
\hline $4 / 12 / 67$ & 1030 & PI-A & 0.95 \\
$4 / 12 / 67$ & 1230 & PI-B & 0.33 \\
$4 / 12 / 67$ & 1430 & PI-A & 0.61 \\
$4 / 12 / 67$ & 1715 & PI-B & 0.28 \\
$4 / 13 / 67$ & 1845 & PI-A & 0.49 \\
$4 / 13 / 67$ & 2240 & PI-B & 0.72 \\
\hline
\end{tabular}

A series of sodium samples was taken from the secondary sodium system on April 14, using the same sampling equipment as had been used for the primary sodium sampling of April 1-3. The purpose of this work was to check the scatter of analytical results for samples from a large system which should be uniform and constant in copper concentration. The results appear in Table $\mathrm{V}$.

TABLE V. Copper Analyses of Secondary Sodium on April 14, 1967

\begin{tabular}{lc|cc}
\hline Time & Copper $(\mathrm{ppm})$ & Time & Copper (ppm) \\
\hline 1755 & 0.33 & 2145 & 0.36 \\
1835 & less than 0.25 & 2215 & less than 0.25 \\
1920 & 0.27 & 2245 & 0.41 \\
2010 & 0.28 & 2315 & 0.25 \\
2040 & 0.44 & 2345 & less than 0.25 \\
2115 & 0.27 & & \\
\hline
\end{tabular}


On April 18 and 19, 196.7, samples were taken from the primary cold-trap. influent and effluent with different flowrates through the cold trap. The copper analyses for these samples are presented in Table VI. There is no obvious effect.of flowrate upon copper concentrations.

TABLE VI. Copper Analyses:for April 18 and 19, 1967

\begin{tabular}{lcccc}
\hline Date & Time & $\begin{array}{c}\text { Sample } \\
\text { Point }\end{array}$ & $\begin{array}{c}\text { Cold-trap } \\
\text { Flowrate } \\
\text { (gpm) }\end{array}$ & Copper (ppm) \\
\hline $4 / 18 / 67$ & 1215 & PI-A & 1.5 & 0.45 \\
$4 / 18 / 67$ & 1550 & PI-B & 15 & 1.89 \\
$4 / 18 / 67$ & 1730 & PI-A & 1.5 & 0.49 \\
$4 / 18 / 67$ & 1850 & PI-B & 15 & 0.45 \\
$4 / 18 / 67$ & 1945 & PI-A & 15 & 0.43 \\
$4 / 18 / 67$ & 2040 & PI-B & 15 & 0.40 \\
$4 / 19 / 67$ & 0930 & PI-A & 10 & 0.43 \\
$4 / 19 / 67$ & 10.30 & PI-B & 10 & 0.31 \\
$4 / 19 / 67$ & 1140 & PI-A & 10 & 1.20 \\
$4 / 19 / 67$ & 1230 & PI-B & 10 & 0.64 \\
$4 / 19 / 67$ & 1310 & PI-A & 5 & .32 \\
$4 / 19 / 67$ & 1.345 & PI-B & 5 & 0.38 \\
$4 / 19 / 67$ & 1405 & PI-A & 5 & 0.46 \\
$4 / 19 / 67$ & 1430 & PI-B & 5 & les.s than 0.25 \\
$4 / 19 / 67$ & 1450 & PI-A & 5 & 0.66 \\
\hline
\end{tabular}

3. EBR-II Driver Fuel Development and.Metallurgical Assistance

a. Anomalous Swelling of Mark-IA Fuel. A series of experiments are being undertaken to determine in CP-5 the effects of various parameters such as pressure, heat treatment, and impurities, acting individually and combined, on the anomalous irradiation swelling behavior of U- $5 . \mathrm{w} / \mathrm{O}$ Fs alloy pins (see.Progress Report for March 1967, ANL-7317, pp. 8-12). Now in preparation, the first of these experiments will be to investigate the effect of superimposed pressure on fuel-pin swelling. To achieve this, six 0.144-in.-dia by: 1.00-in.-long specimens cut from a single EBR-II fuel pin are being prepared for encapsulation under gas pressure inside 0.25 -in.-OD by 0.15-in.-wall Inconel-625.tubes. Each specimen will be pressurized at a different internal pressure to enable an evaluation to be made of the effect of external swelling on swelling rate of the fuel alloy. The range from 5.0 to $2000 \mathrm{psi}$ has been selected for study. This range will be covered in steps with a. single.specimen at each of the following pressures: $22,44,110,220$, 440, and 880 .psi, which have been'calculated to increase under irradiation conditions and temperature to $50,100,250,500,1000$, and $2000 \mathrm{psi}$, respectively. 
A procedure has been developed for using a Swagelok fitting on each jacketed specimen tube so as to permit the final closure to be electronbeam welded without loss of internal pressure while the interior is under the desired pressure. Methods for leak testing the final closure and for verifying that no pressure loss has occurred during final closure have been experimentally demonstrated. In the leak testing, the helium gas sealed within each individual tube is searched for with a helium mass-spectrometer leak detector. Verification of internal pressure is achieved by means of a miniature strain gauge cemented on the outer diameter of the specimen jacket. Strain gauges will be used on the jackets of all the encapsulated specimens used in the reactor experiment. These gauges and the Swagelok fitting will be removed before assembly into the test capsule.

b. Mark-II tuel-element Development. Calculations have been completed for the Safety Analysis Report for irradiation of encapsulated Mark-II elements in EBR-II.

Sixty-two elements are being fabricated. Thirty-seven will constitute the initial subassembly:loading; the remainder will be utilized as replacements in the subassembly as elements are removed for inspection at $1,2,3,4$, and 5 a/o burnup.

\section{Reactor Improvements}

a. Irradiated-fuel Monitor. Because of the long (30-week) delivery schedule for a monoball-type bearing planned for use in the mechanism, an available substitute will be used. This has necessitated modification of parts in the connection between the drive mechanism and the sensor extension. Fabrication of hardware (see.Progress Report for January 1967, ANL-7302, pp. $11-12$ ) is $\sim 80 \%$ complete.

b. Sodium-chemistry Technology. In connection with analyses of possible causes of and problems for copper contamination in the primarysystem sodium (see Progress Report for March 1967, ANT،-7317, pp.4-7), the original plugging-loop (PI-A) economizer is being examined destructively, and plans are being made for a new plugging loop and sampling station.

(i) Examination of Plugging-loop Economizer. The entire economizer was $\mathrm{X}$-rayed in a search for gross deposits of $\mathrm{Cu}, \mathrm{Na}_{2} \mathrm{O}$, or other material; no deposit of any, kind was found. However, the radiographs did reveal a deformed or flattened section of the 0.5-in.-OD tube within the 0.75 -in. (nominal-pipe-size) Schedule-40.shell. The radiographic evidence revealed that the flattened region is $\sim 13$ in. long and centrally located (that is, $\sim 8$ in. from either end of the economizer); measurements of several sets of radiographs indicated that the major and minor axes of the deformedtube cross section are $11 / 16$ and 5/16 in. 
A 3-in.-long section was cut from the upper and lower ends of the economizer so surfaces could be inspected and samples of frozen sodium obtained for analysis. After the shell halves of the two end sections were slit and laid open, frozen-sodium samples were taken and are being analyzed. The sodium remaining on these shell pieces was dissolved with ethanol, and the surfaces were then examined and photographed. On the surfaces on which copper had been deposited, the deposit is friable and a considerable portion sloughed off because of the agitation when the -sodium and ethanol reacted. Close examination of the shell halves during and after the reaction revealed copper deposited in the lower 3 -in. section, but no visual evidence of copper on the upper 3 -in. section.

This information indicates that between the time sodium enters at the bottom of the shell and the time it emerges at the top, changes in flow, temperature, and copper solubility bring about conditions that result in copper deposition at the lower end of the economizer but no deposition at the top.

Planned examination of the entire inner surface of the shell will disclose the exact location of the transition region. Chemical analyses of sodium samples taken from various sections and recovery of the deposited copper from all sections will furnish a profile of copper concentration for the entire economizer.

(ii) New Plugging Loop and Samplïng Station. A new sodium plugging indicator and sodium-bypass freeze sampler were proposed for installation in the EBR-II Fuel Element Rupture Detection (FERD) loop. Preliminary concepts have been designed. All details of the plugging indicator have been decided, and final design is underway. However, some aspects of the concept for the freeze sampler are still under consideration.

The new proposed sodium plugging-indicator loop will be located on the discharge side of the main FERD loop pump and will consist of a plugging valve with serrated stem ( 12 grooves, each 0.031 in. deep by 0.031 in. wide), a sodium-to-sodium heat economizer, a magnetic flowmeter, a small electromagnetic pump $(\sim 3 / 4 \mathrm{gpm})$, and two isolation valves. Except for having the pump control the sodium flow rather than having a throttle controlling system pressure drop, the loop is es sentially similar to the ones now used at EBR-II. Means will be provided for controlled air cooling and plugging-valve maintenance and/or removal.

The sodium-bypass freeze sampler, as initially proposed, would consist of a 0.5-in.-dia U-shaped nickel tube with a total length of $\sim 24$ in. The sample tube would be connected across the FERD-loop main pump and be subjected to its normal differential pressure; estimated flow through the tube would be $11 \mathrm{ft} / \mathrm{sec}$. The tube, which would be at the highest 
point of the FERD loop; would be easily accessible from the operating floor and would require a minimum of modifications and additions to the radiation shielding.

c. Rotating-plug Seal Cleaning System. Improvements were made in the oxide-removal devices and the circulation system for the bismuthtin alloy. The shape of the collector tank for the skimming mechanism (see:Monthly Progress Report for March 1967,. ANL-7317, pp. 12-13) has been modified to increase the efficiency of oxide removal. The new tank configuration performed very well in tests in the laboratory mockup, but further improvement is expected as a result of design changes being made on the skimming mechanism. The alloy return line and discharge nozzle are being modified to improve flow characteristics. A prototype centrifugaltype oxide separator is being fabricated for initial testing in the laboratory mockup of the system.

d. Irradiation Subassembly Mark C. Hardware was received for hydraulic studies of the Mark-C19 irradiation subassembly. This subassembly contains nineteen elements of 0.290 -in. OD and 44 -in. length, and incorporates the coolant-bypass feature that permits acceptable subassembly mixed-coolant outlet temperature with much higher coolant temperatures at the element exit. Hydraulic studies of the Mark-C37 subassembly (see Progress Report for March 1967, ANL-7317, p. 13) and Mark-C mixing studies were completed.

e. Ir radiation Subassembly Mark E. Preliminary design concepts have been initiated to provide a.subassembly capable of withstanding the physical damage resulting from a postulated failure of fuel-element cladding. The subassembly structure must contain all fragments or portions of the fuel element without adverse effect or damage to adjacent subassemblies and other reactor components. Calculations and analyses on the first concept led to a second concept that incorporates an increased quantity of temperature-resistant material; these modifications are being evaluated.

f. Fuel Subassembly Mark..II. Drawings of durnmy lest fuel elements and four designs of shield configurations have been completed. The Mark-I fuel subassembly Model-STB was tested hydraulically to measure the pressure drop in the existing major components, specifically the lower shield, fuel elements, and the upper shield. These measurements will be compared with those of the new Mark-II components to match the pressure drop of the Mark-II subassembly with existing fuel subassemblies.

g. Instrumented-subassembly System. Effort continued toward developing the systems concept and equipment requirements necessary to place instrumented subassemblies in the reactor core. 
(i) Operating Mechanism. A reference design for the operating mechanism has been completed, in which the subassembly. is moved vertically so that the rotating plug can be indexed. As shown in Fig. 1, the various mechanism parts have been arranged to form a compact unitized structure, which can be readily attached to the upper section of the central control-rod support column. Because of its compactness, the mechanism can be installed in any of the 12 spaces now occupied by control-rod drives.

The essential parts of the mechanism are: (a) drive apparatus for rotating the lead screw, installed on top of the mechanism, (b) drive screw for changing rotating to vertical motion of the elevator plate, (c) a terminal box for instrument leads, attached to the elevator plate, and (d) the motorized extension-tube seal and bellows. The seal surrounds the extension tube inserted between the instrumented subassembly and the instrument-lead terminal box (see Progress Report for February 1967, ANL-7308, p. 5).

Figure 1 also shows the method for mechanically coupling the extension tube and terminal box to the elevator plate such that the forces required to raise or lower the instrumented subassembly can be observed at all times. Note the location of the limit switches that arrest further motion if frictional forces in the seal or extension tube become high.

h. Higher-worth Control Rod. So that up to four of the present 12 control-rod locations in the core could be made available for installation of an oscillating rod, instrumented irradiation subassemblies, or other special in-core experimental devices, studies are being made of methods by which to increase the reactivity effectiveness of the remaining eight control rods, which now contain fuel. Preliminary.dimensional layout and analysis show that this rod will likely be an all-absorber rod rather than consisting of fuel rods with an absorber follower. The gas space required in the top of the fuel elements limits the proximity of any absorber section to the fuel section to the extent that only an inadequate portion of the absorber section could enter the reactor core. Efforts are being made to increase the boron carbide absorber material commensurate with cooling requirements.

i. Oscillator Rod Mark II. During routine transfer-function measurements of the EBR-II, the effort required to turn the Mark-II oscillator rod increased markedly at very slow speeds and high reactor temperature differentials. Removal and subsequent inspection of the rod revealed rubbing marks on one side of the rod. It was concluded that these rubbing marks were caused by a combination of rod bowing and thimble bowing at the lower speeds and higher temperature differentials. 


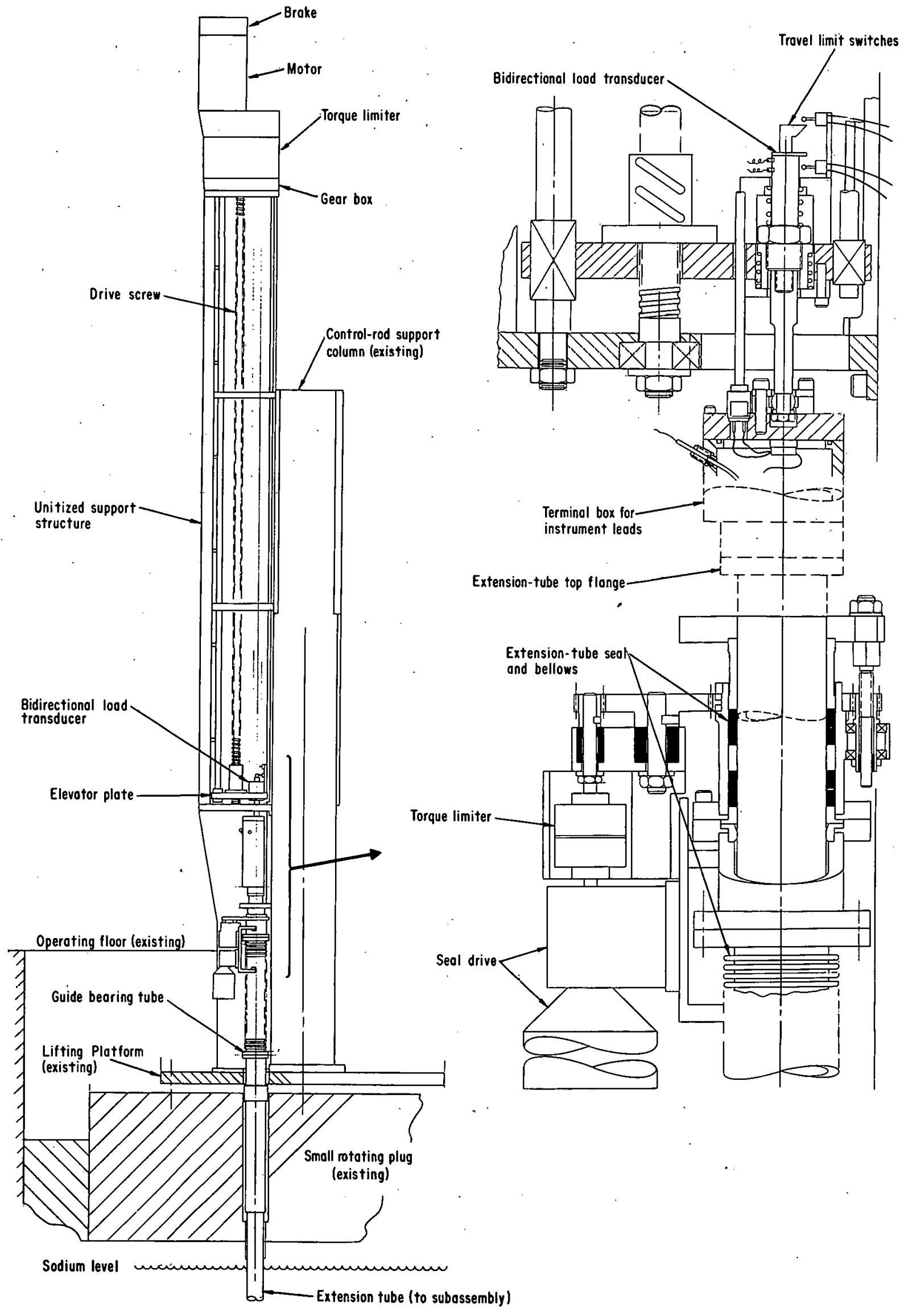

Fig. 1. Instrumented-subassembly Operating Mechanism; Overall at Left, Detail at Right 
As a.first step to correct this condition, design changes are being studied. If the rod were $0.2 \mathrm{in.} \mathrm{smaller}$ in diameter, the rod and thimble could bow somewhat without interfering with each other. A more effective balance of heat generation within the rod would lessen the bowing of the rod; a scheme being studied would involve balancing the boron carbide capsule within the oscillator rod with a uranium oxide rod.

A special thimble for use with the oscillator-rod assembly would replace the standard control-rod.thimble in the reactor. The bottom of the thimble would have a spring-loaded bayonet, which, when locked to the reactor grid pin, would cause the thimble to exert a downward seating force of about $230 \mathrm{lb}$ on the top grid plate. This seating force would stabilize the thimble and provide a firm housing for the oscillator-rod lower bearing. The thimble would have a pin fastened to its lower end, to which the oscillator-rod assembly bayonet would lock. Thus, by locking the oscillator-rod assembly to the thimble pin instead of to the grid pin, the oscillator-rod assembly would be isolated completely from the reactor grid, thereby reducing the possibility of handling difficulties.

The os cillator-rod assembly also could be shortened to permit its storage in the storage basket. To accommodate the oscillator-rod assembly, a sleeve for receiving the rod assembly would be locked into a storage tube in the outer row of the storage basket. A special gripper would be used to install and lock the sleeve in the storage-basket tube. The gripper may also be used to remove the sleeve from the basket.

\section{j. Modification for Increased Fuel Production}

(i) Bonders. The new bonders have been delivered. Calibration of the assembled system is scheduled to start the second week in May. Additional testing will be performed on this unit to prove a new zone-heater control design. Optimum thermocouple locations will be selected prior to installation in the Argon Cell.

(ii) Bond Tester. The readout equipment has been field-tested on an existing system and has been accepted for operation. Work on the controls is approximately $60 \%$ complete.

k. Nuclear Instrumentation. Circuit-design work has started for adaptation of the new equipment to the existing reactor protective circuit and readout equipment. Life testing of relays used in the system for final control has continued.

A check.with the equipment manufacturer was made and his report is that the equipment deliveries remain firm as stated. 


\section{Reactor Systems Instrumentation}

(i) Temperature-monitoring Devices. The detailed circuit modifications necessary to interconnect the new equipment to the existing systems is approximately $60 \%$ complete. The monitor switches ordered have been delivered, and the modifications necessary for fail-safe operation will start the first week in May. No change in delivery of the remaining equipment is anticipated.

(ii) Miniature Recorders. Work was started on the alarm and control functions, and then stopped to complete work on the bulk-sodiumlevel system. Completion of the necessary engineering will be scheduled for May.

The float-operated, bulk-sodium-level indicator has been installed in the primary tank, and connected to the readout and control instrumentation. The unit will be monitored closely for operation for one or more reactor operating periods before substituting it for existing level equipment. Two sets of alarms have been set up for monitoring. One set of high and low alarms have been preset to actuate a mechanical counter at \pm 1 in. from normal level and a second set at \pm 3 in. The normal reactor scram points for the system are \pm 3 in. Since the system has been placed into operation, no trips have occurred due to noise.

\section{m. Selected Parameter Data Processing System}

(i) 100-point System. Manufacturing follow-up has continued; although the manufacturer states he will deliver on time, it is somewhat doubtful.

(ii) 50-point Scanner. The 50-point system has been installed and the operation debugged. Work is in progress aligning the system for operation on plant parameters. The system will be in operation by April 26, 1967.

\section{Surveillance}

a. Effect of Stress on Type 304 Stainless Steel Exposed to Sodium. Earlier wor $\mathrm{k}^{1}$ indicated that stressed Type 304 stainless steel is affected more adversely by $1200^{\circ} \mathrm{F}$ sodium than is the unstressed material. Further screening tests on as-received samples of EBR-II radial-blanket tubing have continued (see Progress Report for February 1967, ANL-7308, pp. 5-7). After samples of Type 304 stainless steel tubing were exposed for 6 days to various environments in stressed or unstressed conditions, the specimens

${ }^{1}$ Smith, F. A., et al., $1200^{\circ} \mathrm{F}$ Sodium-free-surface, Stress, and Wear Effects on Reactor-component Metals, IAEA Symposium, SM-85/22, Vienna, December 1966. 
were exposed to Strauss reagent for various times, after which the electrical resistivities of the specimens were measured. The Strauss reagent accelerates grain-boundary or sensitization effects. A deadweight method was used to apply an arbitrarily chosen stress of $59 \%$ of the yield strength at $1200^{\circ} \mathrm{F}$. The same deadweight loading fixture was used for exposures to both air and sodium. Test conditions and data are summarized in Fig. 2 , from which it can be seen that:

(i) For the as-received samples, the Strauss test did not affect the resistivity of either the stressed or unstressed samples.

(ii) For the samples exposed to $1200^{\circ} \mathrm{F}$ air (after having been pretreated in a $1200^{\circ} \mathrm{F}$ vacuum for 35 days), the Strauss test increased the resistivity only slightly; there is little difference between the stressed and unstressed samples. These results are in general agreement with the effect of sensitization in air at $1200^{\circ} \mathrm{F}$ to increase the resistivity of Type 304 stainless steel.

(iii) Eor the samples exposed to $1200^{\circ} \mathrm{F}$ sodium (after no pretreatment), the resistivities of both the stressed and unstressed samples increased markedly as a result of the Strauss tests, but the stressed samples were affected much more than were the unstressed samples. The large difference between results for the stressed and unstressed samples was unexpected because the stress: was relatively modest ( $59 \%$ of yield strength). Duplicate samples were tested to evaluate the reliability of the measurements; the spread in the measurements may be related to inclusions or metallurgical differences.

(iv) For the samples exposed to $1200^{\circ} \mathrm{F}$ sodium (after having been sensitized in $1200^{\circ} \mathrm{F}$ vacuum), the unstressed sample was affected considerably, but the stressed sample was affected catastrophically by only 15-min exposure to Strauss reagent. This indicates that presensitized Type 304 stainless steel that is exposed to $1200^{\circ} \mathrm{F}$ sodium when under stress has a microstructure very susceptible to intergranular corrosion.

\section{Experimental Irradiations}

The status of all experimental irradiations in the reactor and the approximate exposure at month's end is shown in Table VII.

Subassembly XO14, containing structural materials samples from GE, NRL, and PNWL, was discharged, disassembled, and the test capsules shipped to the TAN Hot Shop for interim storage and transfer to the cus tomers' shipping containers. The nominal exposure at the midplane position to these capsules was approximately $1.7 \times 10^{22}$ nvt (total flux). Removal was requested by one of the experimenters, and this request received concurrence from the other experimenters and LDO. 


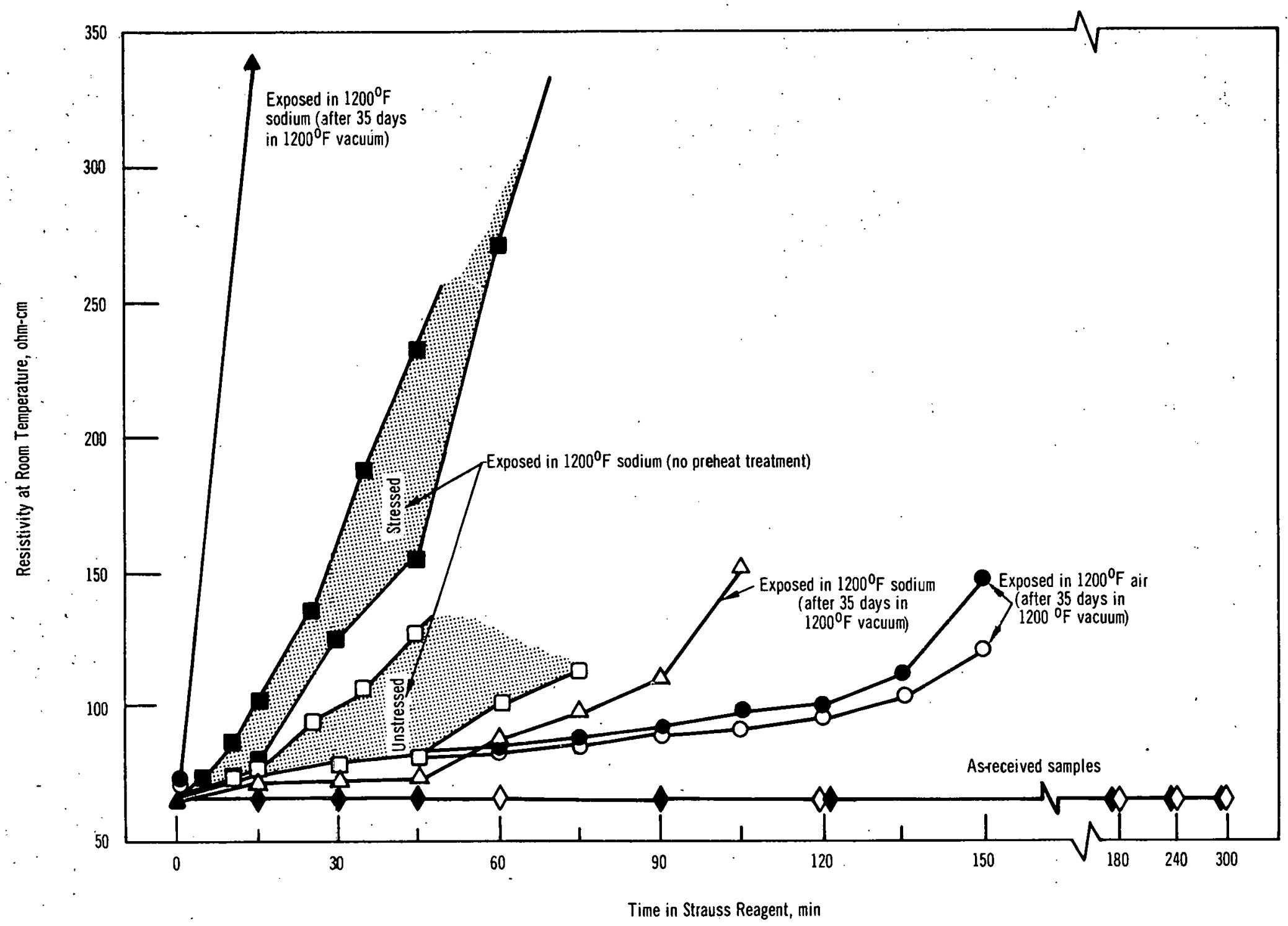

Fig. 2. Rates by Which Strauss Reagent Attacks Samples of Type 304 Stainless Steel That Had Been Stressed (Solid Data Points) or Unstressed (Hollow Data Points) While Being Exposed for 6 days to $1200^{\circ} \mathrm{F}$ Sodium or to $1200^{\circ} \mathrm{F}$ cr Room-temperature Air 
TABLE VII. Status of Experimental Irradiations in EBR-II

\begin{tabular}{|c|c|c|c|c|c|c|}
\hline $\begin{array}{c}\text { Sub- } \\
\text { as sembly }\end{array}$ & $\begin{array}{c}\text { Date } \\
\text { Loaded }\end{array}$ & $\begin{array}{l}\text { Capsule Content anc } \\
\text { Number of Capsules }\end{array}$ & & Experimenter & $\begin{array}{l}\text { Approximate } \\
\text { Accumulated } \\
\text { Exposure } \\
(\mathrm{MWd})\end{array}$ & $\begin{array}{c}\text { Goal } \\
\text { Exposure } \\
(\mathrm{MWd})\end{array}$ \\
\hline $\mathrm{XG02}$ & $7 / 16 / 65$ & $\begin{array}{l}\mathrm{UO}_{2}-20 \mathrm{w} / \mathrm{o} \mathrm{PuO}_{2} \\
\text { Stainless Dummies }\end{array}$ & $\begin{array}{l}(1) \\
(18)\end{array}$ & GE & 9,844 & 13,600 \\
\hline $\mathrm{XG03}$ & $7 / 16 / 65$ & $\begin{array}{l}\mathrm{UO}_{2}-20 \mathrm{w} / \mathrm{o} \mathrm{PuO}_{2} \\
\text { Stainless Dummies }\end{array}$ & $\begin{array}{r}(2) \\
(17)\end{array}$ & $\mathrm{GE}$ & 9,844 & 19,450 \\
\hline XG04 & $7 / 16 / 65$ & $\begin{array}{l}\mathrm{UO}_{2}-20 \mathrm{w} / \circ \mathrm{PuO}_{2} \\
\text { Stainless Dummies }\end{array}$ & $\begin{array}{l}(2) \\
(17)\end{array}$ & GE & 9,844 . & 39,000 \\
\hline XG05 & $9 / 3 / 65$ & $\begin{array}{l}\mathrm{UO}_{2}-20 \mathrm{w} / 0 \mathrm{PuO}_{2} \\
\mathrm{U}-15 \mathrm{w} / 0 \mathrm{Pu}-10 \mathrm{w} / 0 \mathrm{Zr} \\
\mathrm{U}-15 \mathrm{w} / 0 \mathrm{Pu}-10 \mathrm{w} / 0 \mathrm{Ti} \\
\mathrm{UC}-20 \mathrm{w} / \mathrm{OuC} \\
\text { Structural }\end{array}$ & 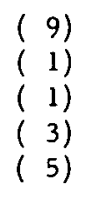 & $\begin{array}{l}\text { GE } \\
\text { ANL } \\
\text { ANL } \\
\text { ANL } \\
\text { GE }\end{array}$ & 9,417 & 14,750 \\
\hline $\mathrm{XA08}$ & $12 / 13 / 65$ & $\begin{array}{l}\mathrm{UC}-20 \mathrm{w} / \mathrm{o} \mathrm{PuC} \\
\text { Structural }\end{array}$ & $\begin{array}{l}(8) \\
(11)\end{array}$ & ANL & 7,595 & 19,800 \\
\hline XO10 & $3 / 24 / 66$ & $\begin{array}{l}\mathrm{UO}_{2}-20 \mathrm{w} / \mathrm{o} \mathrm{PuO}_{2} \\
\text { Structural } \\
\text { Structural }\end{array}$ & $\begin{array}{l}(4) \\
(11) \\
(4)\end{array}$ & $\begin{array}{c}\text { GE } \\
\text { ANL } \\
\text { PNWL }\end{array}$ & 6,775 & 19,600 \\
\hline XO11 & $5 / 9 / 66$ & $\begin{array}{l}\mathrm{UO}_{2}-20 \mathrm{w} / \mathrm{o} \mathrm{PuO}_{2} \\
\mathrm{UO}_{2}-20 \mathrm{w} / \mathrm{o} \mathrm{PuO}_{2} \\
304 \mathrm{SS}-30 \mathrm{w} / \mathrm{PuO}_{2} \\
304 \mathrm{SS}-20 \mathrm{w} / \mathrm{PuO}_{2} \\
304 \mathrm{SS}-20 \mathrm{w} / \mathrm{OOO}_{2}\end{array}$ & $\begin{array}{l}(7) \\
(9) \\
(1) \\
(1) \\
(1)\end{array}$ & $\begin{array}{l}\text { ANL } \\
\text { GE } \\
\text { PNWL } \\
\text { PNWL } \\
\text { PNWL }\end{array}$ & 6,204 & 8,300 \\
\hline $\mathrm{x} 012$ & $8 / 10 / 66$ & $\mathrm{UO}_{2}-20 \mathrm{w} / \mathrm{o} \mathrm{PuO}_{2}$ & (19) & NUMEC & 3,075 & 20,600 \\
\hline XO15 & $11 / 15 / 66$ & $\begin{array}{l}\mathrm{PuO}_{2}-\mathrm{UO}_{2} \\
\mathrm{PuO}_{2}-\mathrm{UO}_{2} \\
(\mathrm{Pu}, \mathrm{U}) \mathrm{C} \\
\mathrm{MK}-\mathrm{IA} \text { (Metal) }\end{array}$ & $\begin{array}{l}\left(\begin{array}{ll}1 & 1\end{array}\right) \\
(2) \\
(4) \\
(2)\end{array}$ & $\begin{array}{c}\text { NUMEC } \\
\text { GE } \\
\text { ANL } \\
\text { ANL }\end{array}$ & 1,420 & 11,000 \\
\hline xọ16 & $1 / 13 / 67$ & $\begin{array}{l}\text { Structural } \\
\text { Structural }\end{array}$ & $\begin{array}{r}(9) \\
(10)\end{array}$ & $\begin{array}{l}\mathrm{ANL} \\
\mathrm{GE}\end{array}$ & 100 & 3,000 \\
\hline $\mathrm{XO} 17$ & $11 / 15 / 66$ & $\begin{array}{l}\mathrm{PuO}_{2}-\mathrm{UO}_{2} \\
(\mathrm{Pu}, \mathrm{U}) \mathrm{C} \\
\mathrm{MK}-\mathrm{IA} \text { (Metal) }\end{array}$ & $\begin{array}{l}\left(\begin{array}{l}1 \\
(\end{array}\right) \\
\left(\begin{array}{l}3 \\
5\end{array}\right)\end{array}$ & $\begin{array}{l}\text { NUMEC } \\
\text { UNC } \\
\text { ANL }\end{array}$ & 1,420 & 6,500 \\
\hline $\mathrm{xO} 18$ & $12 / 6 / 66$ & $\begin{array}{l}\text { Structural } \\
\text { Structural } \\
\text { Structural } \\
\text { Struclus al and Hoavy } \\
\text { Metal Fission Yield } \\
\text { Samples }\end{array}$ & $\begin{array}{l}(3) \\
(1) \\
(2)\end{array}$ & $\begin{array}{l}\text { GE } \\
\text { PNWL } \\
\text { ANL }\end{array}$ & 730 & 21,300 \\
\hline XO19 & $1 / 13 / 67$ & $\begin{array}{l}\mathrm{UO}_{2}-20 \mathrm{w} / \mathrm{O} \mathrm{PuO}_{2} \\
\left(\mathrm{U}_{0.8} \mathrm{Pu}_{0.2}\right) \mathrm{C} \\
\text { Structural } \\
\text { Graphite }\end{array}$ & 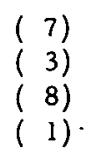 & $\begin{array}{l}\text { GE } \\
\text { UNC } \\
\text { PNWL } \\
\text { PNWL }\end{array}$ & 100 & $7,500^{a}$ \\
\hline XO20 & $1 / 13 / 67$ & $\begin{array}{l}\mathrm{UO}_{2}-20 \mathrm{w} / 0 \mathrm{PuO}_{2} \\
\left(\mathrm{U}_{0.8} \mathrm{Pu}_{0.2}\right) \mathrm{C} \\
\text { Structural } \\
\text { Structural } \\
\text { Graphite }\end{array}$ & $\begin{array}{l}(9) \\
(3) \\
(4) \\
(2) \\
(1)\end{array}$ & $\begin{array}{l}\text { GE } \\
\text { UNC } \\
\text { FNWL } \\
\text { ANL } \\
\text { PNWL }\end{array}$ & 100 & $7,500^{\mathrm{a}}$ \\
\hline $\mathrm{xO} 21$ & $2 / 27 / 67$ & Structural & $(7)$ & PNWL & 100 & 21,500 \\
\hline $\mathrm{XO} 22$ & $2 / 27 / 67$ & Structural & $(7)$ & PNWL & 100 & 8,000 \\
\hline
\end{tabular}

$\mathrm{a}_{\text {Being considered for further exposure. }}$ 


\section{Vertical Assembler-Disassembler ( $\dot{V} \dot{A} D)$}

Assembly of the VAD mechanical components was completed on April 24, 1967; assembly and wiring of the control console has almost been completed. Preparation of installation drawings is still under way.

Operational tests are continuing and have been expanded to the testing of interrelated machine systems. Satisfactory results have been obtained in a limited number of tests of the hex tube cutter, the welding heads, and power supply. The positioning accuracy of the vertical drive units, as wcll as force-limiting and-measuring features of the machine are better than the design requirements. A test of ease of remote disassembly and reassembly was made. A number of handling fixtures and modifications, seen to be needed at that time, have now been completed. We have been able to make up the time lost during contracting and fabrication of the machine components and are now on schedule.

A final test and rehearsal of operating and installation procedures will be conducted between May 1 and 5. It is planned to carry out final plating, greasing, and other preparations prior to packing for shipment, scheduled for May 19.

8. Fuel Cycle Facility: (FCF)

a. Examination of Irradiated Radial Blanket Rods. Nineteen additional rods from 6th, $7 \mathrm{th}, 8 \mathrm{th}$, and 10 th row subassemblies have been sent to Test Area North ( $T A N$ ) for examination. Diametral measurements will be obtained for the jackets and for the declad rods. Length and density values will be obtained for the declad rods. No significant additional data are yet available.

b. Fabrication of Unirradiated Fuel in the FCF (Cold Line). Installation of the alloy-preparation furnace for cold fuel is substantially complete. When this is available, complete test runs with unenriched uranium will be made. The injection-casting cquipment is about $50 \%$ complete; the pin-processing and element-processing units are about $75 \%$ complete. The design of the final assembly machine is about $50 \%$ complete, but existing equipment can be utilized for this purpose. Preparation of the inertatmosphere glovebox for installation is largely accomplished. These components will be installed and tested as soon as they are completed.

The layout work on the Cold-line Assembly Machine is almost completed. This machine will: 1) hold the components of the EBR-II fuel subassemblies in position during the manual assembly of the fuel elements onto the support grid, 2) provide a device to push on the outer hexagonal tube, and 3) align the subassembly during the welding of the hex tube. A simple and inexpensive method of incorporating a subassembly pull test has been devised and is being added to the machine. 
Detailing of the major components has begun and some drawings should be ready for release to fabricators by May 15, 1967. All parts are scheduled to be fabricated by October 1, 1967 and the machine installed in Idaho by November 30, 1967.

The status of several modifications are as follows:

(i) Leak Detectors. Control-circuit and componentinterconnecting wiring was started; this work is $40 \%$ complete. The solenoid valves ordered for this unit were rescheduled for delivery by the manufacturer. The new delivery date submitted would have delayed the completion of the cold line. By redesign of the system controls, a second manufacturer's valves can be used. These valves were ordered with delivery scheduled for May 5, 1967, and the original valve order was canceled.

complete.

(ii) Bonder. In-panel control wiring is approximately $90 \%$

(ii) Pin Processor. In-panel wiring is approximately $70 \%$ complete. The balance of the necessary components has been received and can be installed as scheduled.

(iv) Alloy Furnace. Control-circuit and component-interconnecting wiring is $50 \%$ complete. All equipment and hardware have been received for completion of this unit.

c. Procurement of Driver Fuel from Outside Vendors. The Laboratory's recommendations for selection of the vendor of the driver fuel have been submitted to the AEC for action.

d. Facility Modifications and Equipment Additions to the FCF. The vertical assembly-disassembly machine (VAD) is near completion and ready for operational testing in Illinois (see Sect. II.A.7). It will then be reassembled in the FCF mockup area for final testing and training operations. A floor penetration in the mockup area has been provided for this purpose.

Preliminary designs are complete for a neutron radiography source to be located in the Argon Cell for use in nondestructive testing of fuel, blanket, and experimental capsules. The "negative film" will be introduced into the cell via a sealed and shielded feedthrough from the subcell, where it will be exposed and then returned to the basement area. The filmtransfer mechanism will be completely isolated from the cell atmosphere.

To reduce the number of transfers through the Air Cell, a new opening has been made in the wall of the transfer subcell between the Air and Argon Cells. A window and transfer lock will be installed in this opening, 
and two master-slave manipulators will be installed above them. This transfer system will allow all the unirradiated materials, such as crucibles, molds, and waste cans, to be introduced directly into the Argon Cell via the large lock rather than having to traverse the whole length of the Air. Cell. When the mobile decontamination facility is complete, this lock system will also be used to remove equipment components for cleaning and repair.

The design of the top loading-top unloading coffin for transfer of subassemblies to the storage facility of the Idaho Chemical Processing Plant is about $75 \%$ complete.

e. Operations. Subassembly dismantling, processing, and fabrication operations were continued routinely. Both unirradiated and irradiated fuel was used for fuel element fabrication. A total of 16 subassemblies were completed as shown in the operation summary in Table VIII.

TABLE VIII. Production Summary for April 1967

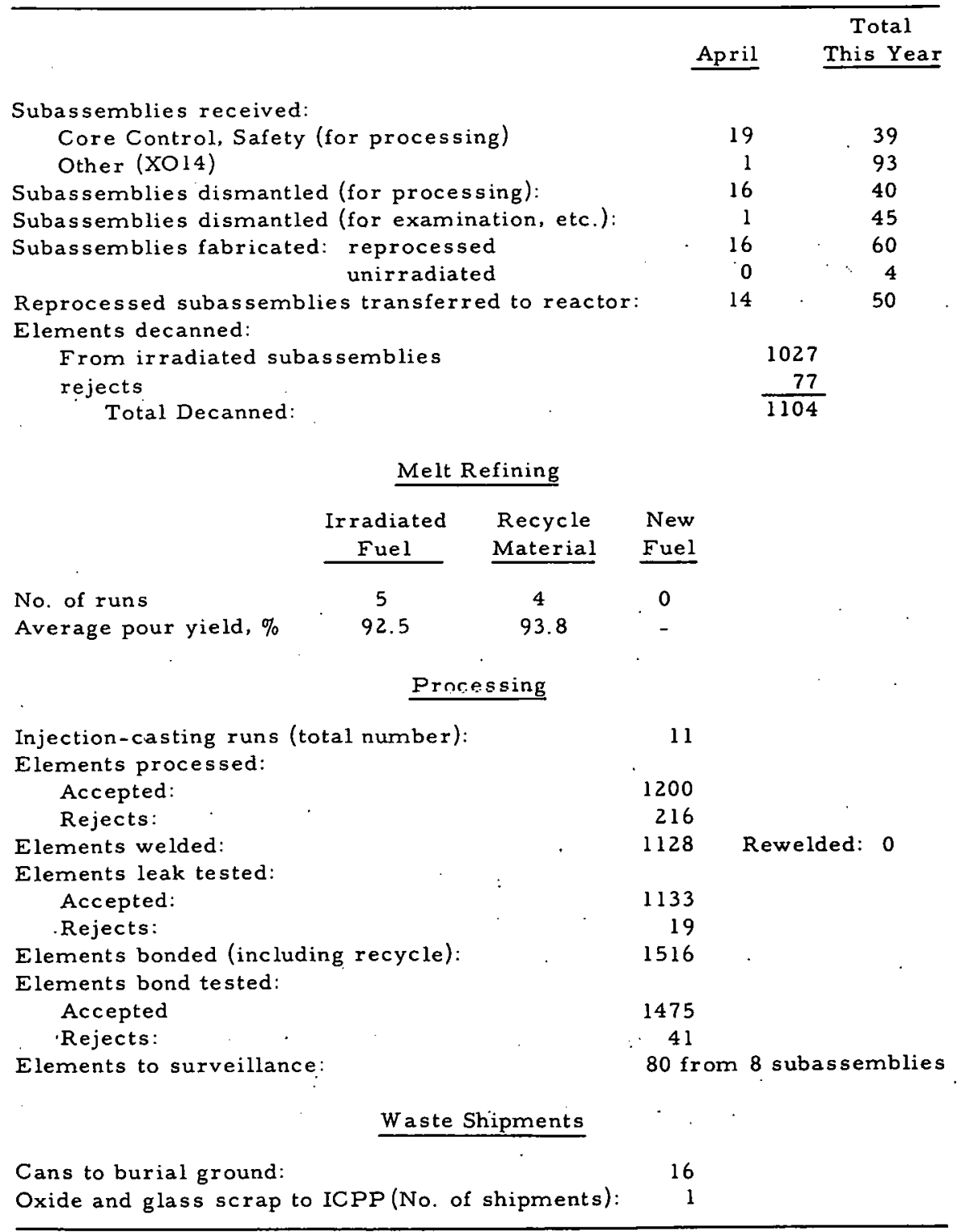




\section{B. Physics Development}

1. $\underline{Z P R}-3$

a. Reactivity Sample Traverses in Assemblies 48 and $48 \mathrm{~A}$.

Analyses of the data from the traverses of reactivity samples through As semblies 48 and $48 \mathrm{~A}$ have been completed. The results obtained for four sets of reactivity sample traverse experiments are given below; they arefor the radial traverses through Assembly 48 (with a depleted uranium radial blanket), and for traverses in Assembly $48 \mathrm{~A}$ with Inconel radial reflector segments (performed in support of the FFTF program) done radially through the reflector, axially through the reflector at the core edge, and radially through $\mathrm{B}_{4} \mathrm{C}$ mockup rods in the reflector. The specifications of the samples used in these experiments are given in Table IX.

TABLE IX. Specifications of Reactivity Samples Used in Assembly-48 Traverses

\begin{tabular}{|c|c|c|c|c|c|c|c|c|}
\hline \multirow[b]{2}{*}{ Sample Material } & & \multirow{2}{*}{ Geometry } & \multicolumn{3}{|c|}{$\therefore \quad \begin{array}{c}\text { Material : } \\
\text { Dimensions (in.) }\end{array}$} & \multirow{2}{*}{$\begin{array}{l}\text { Material } \\
\text { Mass } \\
\text { (g) }\end{array}$} & \multirow{2}{*}{$\begin{array}{c}\text { Can } \\
\text { Mass } \\
(g)\end{array}$} & \multirow{2}{*}{$\begin{array}{l}\text { Material Composition } \\
\qquad(w / 0)\end{array}$} \\
\hline & & & Length & OD & Thickness & & & \\
\hline Plutonium & & Annulus & 1.86 & 0.34 & 0.020 & 9.187 & 6.63 & $95.05 \mathrm{Pu}^{239}, 4.50 \mathrm{Pu}^{240}, 0.45 \mathrm{Pu}^{241}$ \\
\hline Enriched Uranium & & Annulus & 1.90 & 0.39 & 0.010 & 7.128 & 1.79 & $93.16 \mathrm{U}^{235}, 6.84 \mathrm{U}^{238}$ \\
\hline Depleted Uranium & $\cdot$ & Cylinder. & 2.00 & 0.19 & - & 19.63 & - & $99.78 u^{238}, 0.21 u^{235}$ \\
\hline Enriched Boron. & & Annulus & 1.90 & 0.39 & 0.010 & 0.406 & 11.55 & $85.48 \mathrm{~B}^{10}, 7.32 \mathrm{~B}^{11}, 7.2$ impurity \\
\hline Tantolum & & Annulus & 1.98 & 0.38 & 0.015 & 9.67 & 1.77 & $>99 \% \mathrm{Ta}$ \\
\hline Stainless Steel & & Cylinder & 2.00 & 0.42 & - & 35.90 & - & Type 304 , approx $72 \mathrm{Fe}, 18 \mathrm{Cr}, 10 \mathrm{Ni}$ \\
\hline Polyethylene & & Cylinder & 2.00 & 0.42 & - & 4.072 & - & $\mathrm{CH}_{2}$ \\
\hline
\end{tabular}

aStainless steel can or bracket.

bThis composition in suspect, pending confirmation of additional analyses.

Table $X$ presents the results of the radial traverses through Assembly 48 with the reactivity samples. The traverse tube ran through the $P$-row drawers of Half No. 1 about 1 in. back from the interface. In the

TABLE X. Radial Traverses of Reactivity Samples in Assembly 48

\begin{tabular}{|c|c|c|c|c|c|c|c|c|}
\hline \multirow[b]{2}{*}{$\begin{array}{l}\text { Radius } \\
\text { (cm) }\end{array}$} & \multicolumn{8}{|c|}{ Reactivity Coefficient (Ih/kg) } \\
\hline & $\begin{array}{c}\text { Plutonium } \\
\text { (5\% Pu240) } \\
\pm 1\end{array}$ & & $\begin{array}{c}\text { Enriched } \\
\text { Uraniugin } \\
\pm 2\end{array}$ & $\begin{array}{l}\text { Depleted } \\
\text { Uranium } \\
\pm 0.4\end{array}$ & $\begin{array}{c}\text { Enriched } \\
\text { Boron } \\
\pm 20\end{array}$ & $\begin{array}{c}\text { Tantalum } \\
\pm 1\end{array}$ & $\begin{array}{l}\text { Polyethylene } \\
\pm 3\end{array}$ & $\begin{array}{c}\text { Stainless } \\
\text { Steel } \\
\pm 0.3\end{array}$ \\
\hline-73.66 & - & & - & - & $=$. & - & -4 & - \\
\hline-66.04 & 1 & & -1 & 0.4 & -35 & 0.9 & -6 & 0.5 \\
\hline-60.96 & - & & - & - & $=$ & - & -13 & - \\
\hline-55.88 & 6 & & 8 & 0.5 & 2 & 3.0 & -45 & 0.6 \\
\hline-48.26 & 24 & & 21 & 0.0 & -181 & -0.7 & -131 & 2.4 \\
\hline-44.45 & 49 & . & 43 & 1.0 & -335 & -2.4 & -150 & 5.5 \\
\hline-41.59 & 76 & & 64 & 2.0 & -736 & -7 & +4 & 8.2 \\
\hline-38.89 & 103 & & 82 & 0.6 & -1127 & -15 & 238 & 7.6 \\
\hline-33.34 & - & & - & -1.4 & - & - & - & - \\
\hline-27.78 & 229 & & 167 & -5.7 & -3567 & -64 & 916 & 0.4 \\
\hline-16.67 & 367 & & 264 & -13.7 & -6033 & -114 & 1338 & -8.8 \\
\hline-5.56 & 452 & & 324 & -19.0 & -7502 & -150 & 1558 & -14.3 \\
\hline 0.00 & 464 & & 329 & -20.7 & -7679 & -151 & 1585 & -15.4 \\
\hline 5.56 & 450 & & 322 & -18.7 & -7394 & -145 & 1544 & -14.7 \\
\hline 16.67 & 361 & & 255 & -12.4 & -5868 & -112 & 1310 & -7.9 \\
\hline 27.78 & 223 & & 162 & -5.1 & -3422 & -62 & 872 & +1.0 \\
\hline 33.34 & - & & - & -1.8 & - & - & - & - \\
\hline 38.89 & 101 & & 79 & +1.6 & -1084 & -14 & 211 & 7.3 \\
\hline 41.59 & 76 & & 58 & 2.4 & -628 & -2.4 & -10 & 7.0 \\
\hline 44.45 & 47 & & 39 & 1.7 & -345 & -1.5 & -146 & 4.8 \\
\hline 48.26 & 25 & . & 21 & 0.7 & -124 & -1.1 & -125 & 2.1 \\
\hline 55.88 & 6 & & 6 & 0.5 & -7 & +1.0 & -32 & 0.6 \\
\hline 60.9 & - & & $\because \quad$ & - & - & $=\cdots$ & -22 & - \\
\hline
\end{tabular}


table, the negative radii refer to positions in matrix column numbers less than 16, i.e., the axis of the core runs through P-16. The data display a distinct shift of the worth profiles in the negative direction. This reflects the assymetry of the core drawer loading for this assembly, wherein the left half of a Half No. l core drawer (in the negative direction) contains about $90 \%$ more plutonium than the right half. The accuracies quoted at the column heads in the table represent the average reproducibility found in repeated measurements. However, the overall accuracy of the quoted values is limited to about $\pm 3 \%$ because of uncertainties in the calibration of the autorod used for the experiments.

Tables XI and XII present the results of the radial traverses in Assembly 48A (see Progress Report for February 1967, ANL-7308, p. 13, Fig. 4). These traverses were also made through the P-row drawers of Half No. 1. The traverses show the effect of the symmetrically located $\mathrm{B}_{4} \mathrm{C}$ poison rods. The effect of these rods on the reaction rates has previously been presented (ANL-7308, p. 13) and these results show the same asymetries as those in Table $\mathrm{X}$ for Assembly 48.

Table XIII presents the results of the axial traverses taken in the reflector sector. These traverses were made in the center of a reflector drawer one inch from the core-reflector interface. The drawers used were 1 and 2-0-9 and the negative position locations indicate Half No. 2 .

TABLE XI. Radial Traverses of Reactivity Samples in Assembly 48A ${ }^{\text {a }}$

\begin{tabular}{|c|c|c|c|c|c|}
\hline \multirow{2}{*}{$\begin{array}{l}\text { Radial } \\
\text { Position } \\
\quad(\mathrm{cm})\end{array}$} & \multicolumn{5}{|c|}{ Reactivity Coefficient $(\mathrm{Ih} / \mathrm{kg})$} \\
\hline & $\begin{array}{l}\text { Plutoniurn } \\
\left(5 \% \mathrm{Pu}^{240}\right)\end{array}$ & $\begin{array}{l}\text { Enriched } \\
\text { Boron }\end{array}$ & $\begin{array}{l}\text { Depleted } \\
\text { Uranium }\end{array}$ & Tantalum & $\begin{array}{l}\text { Stainless } \\
\text { Steel }\end{array}$ \\
\hline-66.0 & 4.2 & -31 & - & - & -0.2 \\
\hline-55.9 & 38.7 & -120 & 0.9 & -2.0 & 0.3 \\
\hline-48.3 & 92.1 & -605 & 0.8 & -11.0 & 2.9 \\
\hline-43.2 & 129.5 & -1735 & 1.2 & -29.2 & 5.7 \\
\hline-40.6 & 138.0 & -2619 & -1.7 & -46.2 & 6.2 \\
\hline-38.1 & 141.6 & -3490 & -3.1 & -62.6 & 6.7 \\
\hline-35.6 & 156.4 & -3184 & -2.4 & -69.5 & 7.1 \\
\hline-33.3 & 179.1 & -3914 & -3.0 & -70.0 & 5.7 \\
\hline-22.2 & 328.4 & -5504 & - & & -4.0 \\
\hline-11.1 & 453.6 & -7508 & -19.6 & -143.5 & -14.0 \\
\hline-5.6 & - & -8110 & -21.8 & -157.1 & -16.3 \\
\hline 0.0 & 494.7 & -8285 & -22.2 & -162.6 & -16.7 \\
\hline 5.6 & 475.1 & -7992 & -19.9 & -153.8 & -15.4 \\
\hline 11.1 & 443.7 & -7375 & -18.5 & -141.4 & -12.9 \\
\hline 16.7 & 386.4 & -6477 & -15.5 & -123.0 & -8.5 \\
\hline 22.2 & 313.7 & -5345 & - & - & -3.8 \\
\hline 27.8 & 225.4 & -5237 & -13.6 & -93.4 & -2.7 \\
\hline . 33.3 & 167.2 & -3806 & -3.0 & -66.5 & 5.7 \\
\hline 35.6 & 145.4 & -3813 & -4.6 & -68.1 & 6.1 \\
\hline 38.1 & 132.2 & -3401 & -3.8 & 59.3 & 6.6 \\
\hline 40.6 & 128.5 & -2571 & -2.7 & 44.2 & 5.6 \\
\hline 43.2 & $122.8^{\circ}$ & -1673 & -0.6 & -28.1 & 4.7 . \\
\hline 48.3 & 89.3 & -539 & 0.9 & -6.5 & $2.2^{\circ}$ \\
\hline 55.9 & 36.6 & -82 & 0.2 & -1.0 & 0.2 \\
\hline
\end{tabular}

a Core boundary was at 36 and $-36 \mathrm{~cm}$. 
TABLE XII. Radial Traverses of Reactivity Samples in Assembly 48A with $\mathrm{B}_{4} \mathrm{C}$ Poison Rods Inserteda

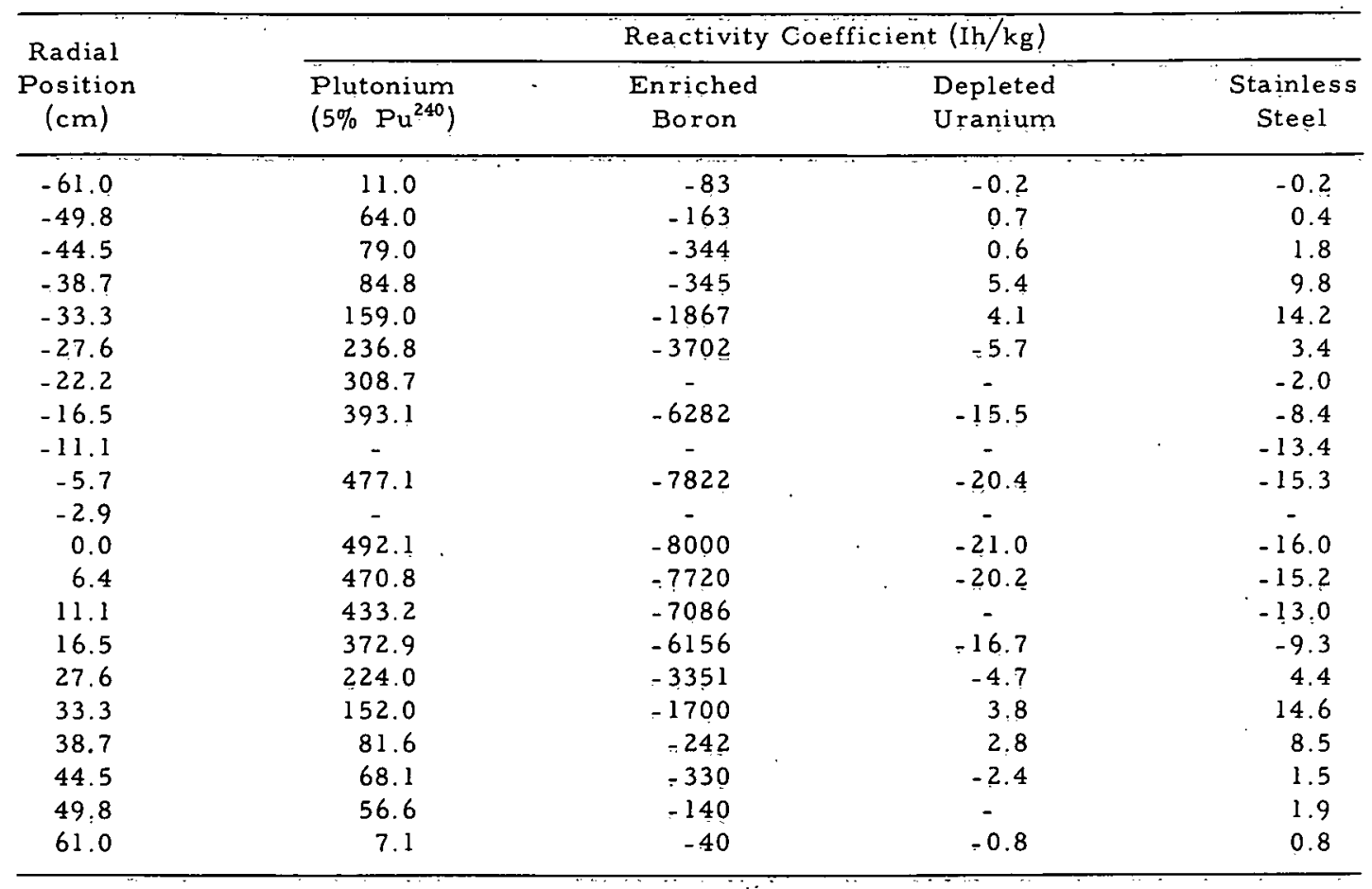

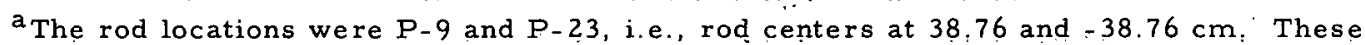
rods were located at the core-reflector interface but completely in the reflector.

TABLE XIII. Axial Traverses of Reactivity Samples in Assembly $48 \mathrm{~A}^{\mathrm{a}}$

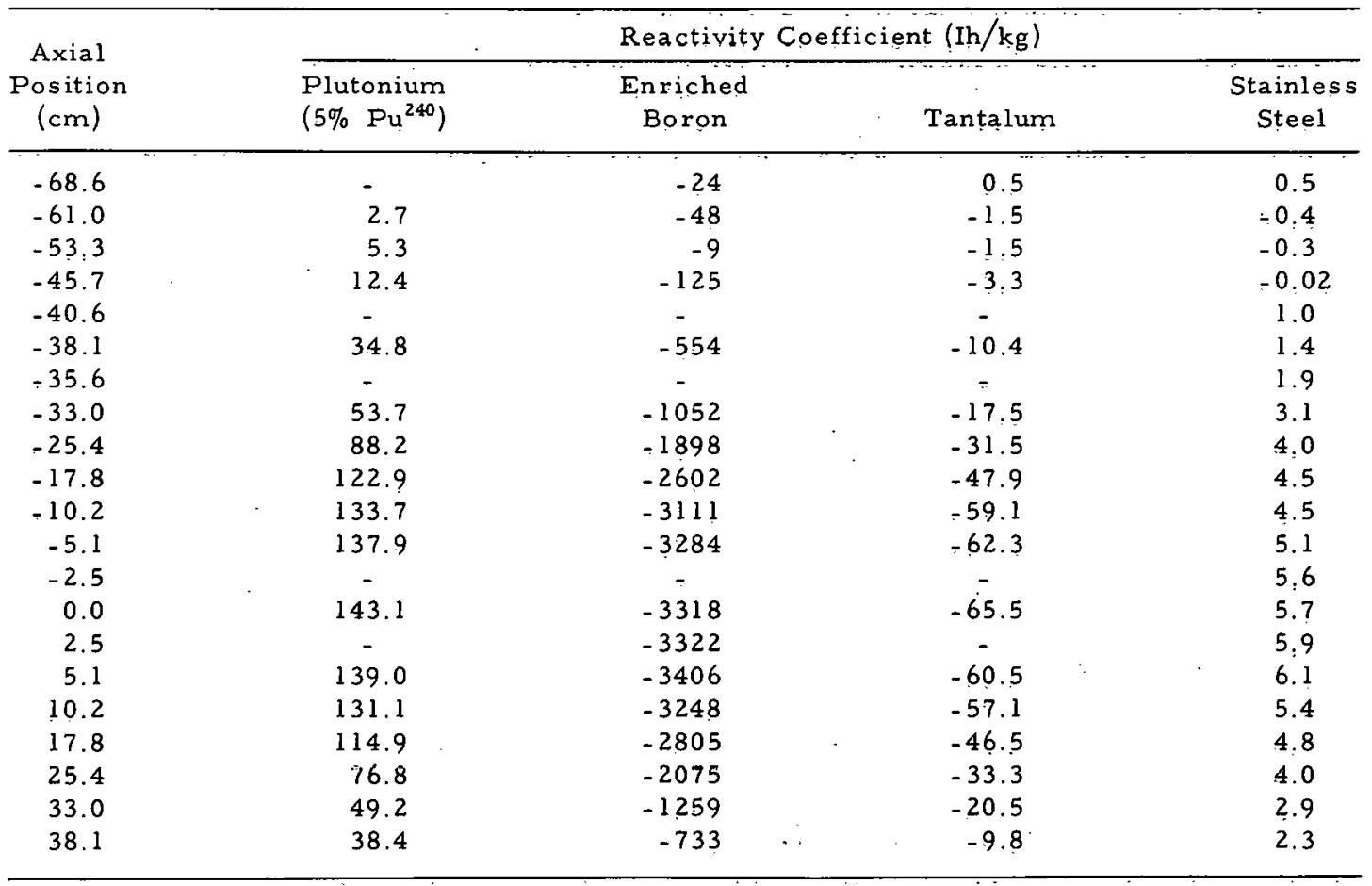

an the Inconel reflector one inch from the core-reflector interface, down the center of 1-0-9 and 2-0-9. 
b. Calculations for the Assembly-48A Results. Values of the $\mathrm{B}^{10}$ and plutonium reaction rates were computed with the use of 22 neutronenergy groups by $\mathrm{MACH}-\mathrm{I}$ code in redimensional cylindrical geometry. Cases considered were with and without control rods.

In Figs. 3 and 4 the measured and computed rates for $B^{10}$ and plutonium are compared.

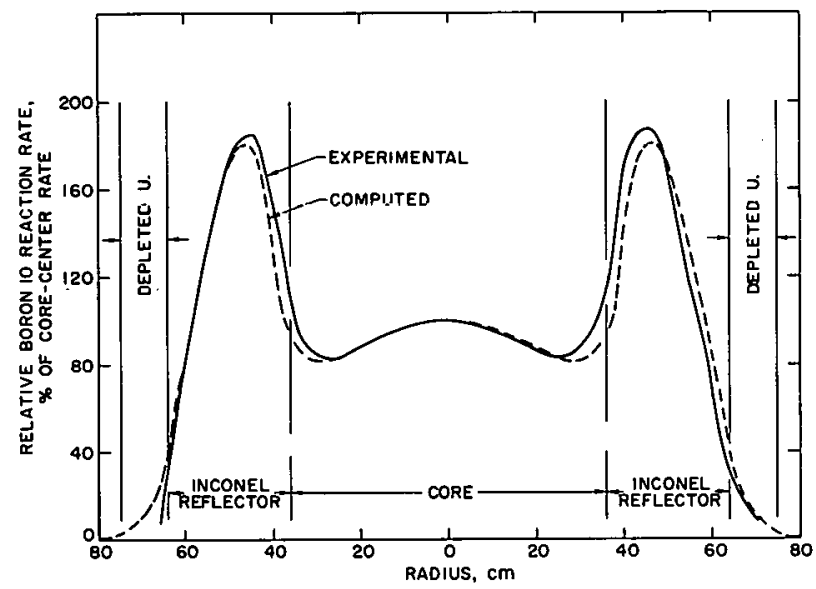

Fig. 3a. Radial Profiles of Boron-10 Reaction Rate through Assembly 48A without Mockup B4C Rods

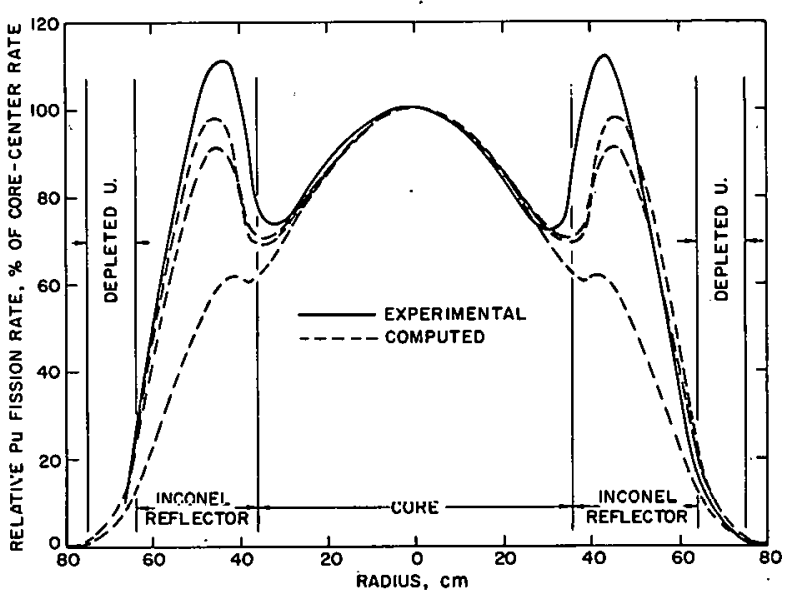

Fig. 4a. Radial Profiles of Plutonium Fission Rate through Assembly 48A without Mockup B4C Rods

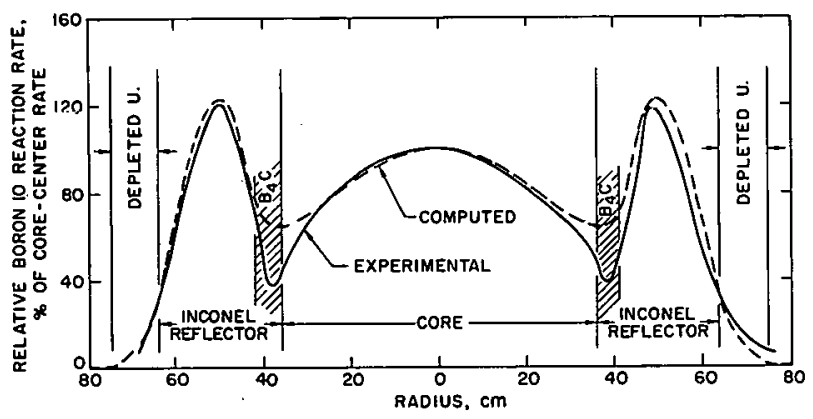

Fig. 3b. Radial Profiles of Boron-10 Reaction Rate through Assembly 48A with Mockup $\mathrm{B}_{4} \mathrm{C}$ Rods

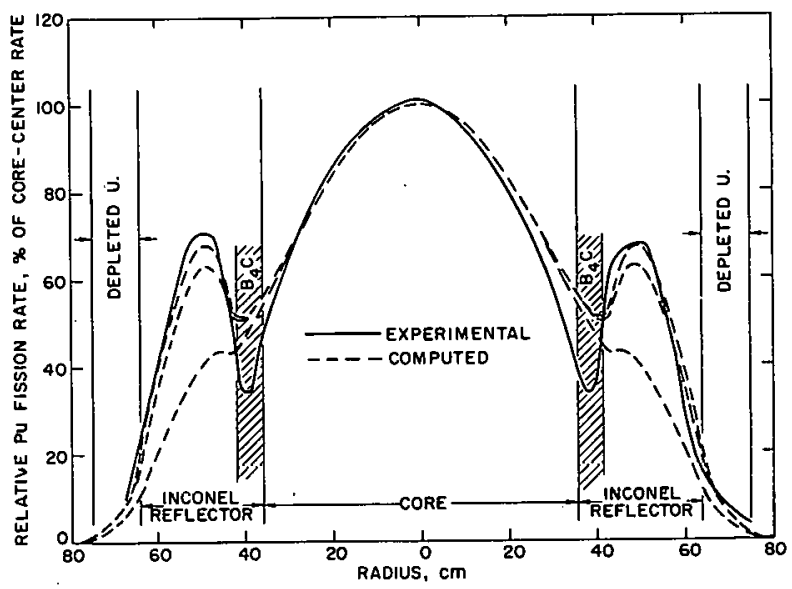

Fig. 4b. Radial Profiles of Plutonium Fission Rate through Assembly $48 \mathrm{~A}$ with Mockup $\mathrm{B}_{4} \mathrm{C}$ Rods

Figure 4 shows three computed curves: the upper curve comes from blanket-averaged cross sections, the middle one is based on reflectoraveraged cross sections, and the lowest one is derived from core-averaged cross sections. Each curve should have been plotted only in the region for which its cross-section input applied, but this would have implied a neutronflux discontinuity at the boundaries between core and reflector and between 
reflector and blanket. Also, because of neutron-spectrum mixing at the boundaries, many more than three sets of cross sections would be needed to give a quasi-continuous reaction rate curve. Since only one cross section was available for $\mathrm{B}^{10}$, only one computed curve appears in Fig. 3 .

The cases without control rods are better simulated by onedimensional cylindrical computations than the case with control rods, since the rods grossly violate the cylindrical symmetry. For the computations with rods, a region was set up in the form of a symmetrical cylindrical shell with a thickness equal to the rod thickness and with inner and outer radii that included both rods. The rod and reflector materials in this region were considered uniformly diluted. The experimental reaction-rate traverse along the radius, on the other hand, passed through the control rod where the $\mathrm{B}_{4} \mathrm{C}$ is concentrated. Because of this situation it was found necessary to double the concentration of rod material in the cylindrical shell in order to depress the reaction-rate maximum in the reflector to the measured value. No attempt was made to add enough rod material to depress the reaction rate in the shell to that measured in the rod, because reactionrate peak in the reflector would then be depressed far below the measured value. This difficulty may possibly be circumvented if a two-dimensional computation is used in noncylindrical symmetry.

c. Assembly 49. As sembly 49 is now loaded in ZPR-3. This is the second in the planned series of plutonium as semblies with a welldegraded neutron spectrum. This series of assemblies aims to provide a set of integral data which can be used for the evaluation of calculation methods and nuclear cross-section compilations employed in the design of large plutonium-fueled power reactors.

The first assembly in this series, Assembly 48 , had a core composition with a $\mathrm{U}^{238} / \mathrm{Pu}^{239}$ ratio of 4.5 , and graphite, sodium, and stainless steel. Assembly 49 has the same core composition as Assembly 48 except that all of the sodium has been removed. Experimental data to be obtained with Assembly 49 will provide important information on the sodiumlnss and Doppler coefficients in cores with and without sodium when compared to results from Assembly 48.

The uncorrected critical mass of Assembly 49 is $282 \mathrm{~kg}$ of plutonium. Currently, edge fuel drawer and control and safety rod measurements are being made to provide data for critical mass corrections.

\section{ZPR-6}

A series of experiments designed to vary the potential scattering cross sections $\sigma_{\mathrm{p}}$ of $\mathrm{U}^{238}$ and consequently vary the effective absorption resonance integral in this material, was performed with Assembly 5 of ZPR-6, a 2600-liter uranium carbide core. Four related effects associated with the variation of $\sigma_{\mathrm{p}}$ of $\mathrm{U}^{238}$ were experimentally investigated. These effects were: 
a. the effect of decreasing $\sigma_{p}$ on the critical mass;

b. the effect of decreasing $\sigma_{p}$ on the sodium-void coefficient;

c. the environmental effects on the bunching of $\mathrm{U}^{238}$ plates;

d. the effect of $\sigma_{p}$ on the absolute fission rates of $U^{235}$ and $U^{238}$ and absolute capture rate of $\mathrm{U}^{238}$ as a function of position in the threedrawer cell.

The bunching of $\mathrm{U}^{238}$ was achieved in two steps. First, the normal three-drawer cell loading (see Fig. 5) was reloaded as shown in Fig. 6. This step was deemed necessary so that the bunching of $\mathrm{U}^{238}$, shown in Fig. 7, would
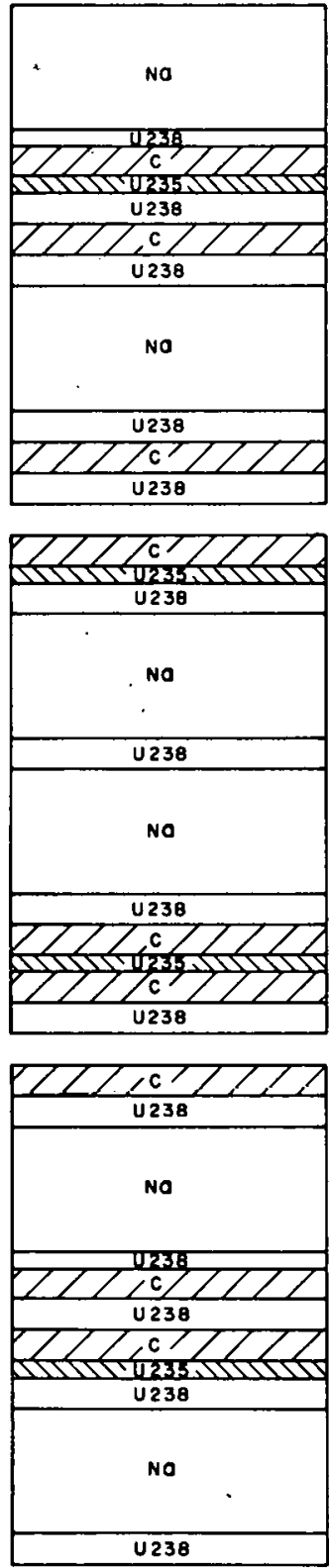

Fig. 5. Normal Loading Pattem of Three-drawer Cell in Assembly 5 of ZPR-6
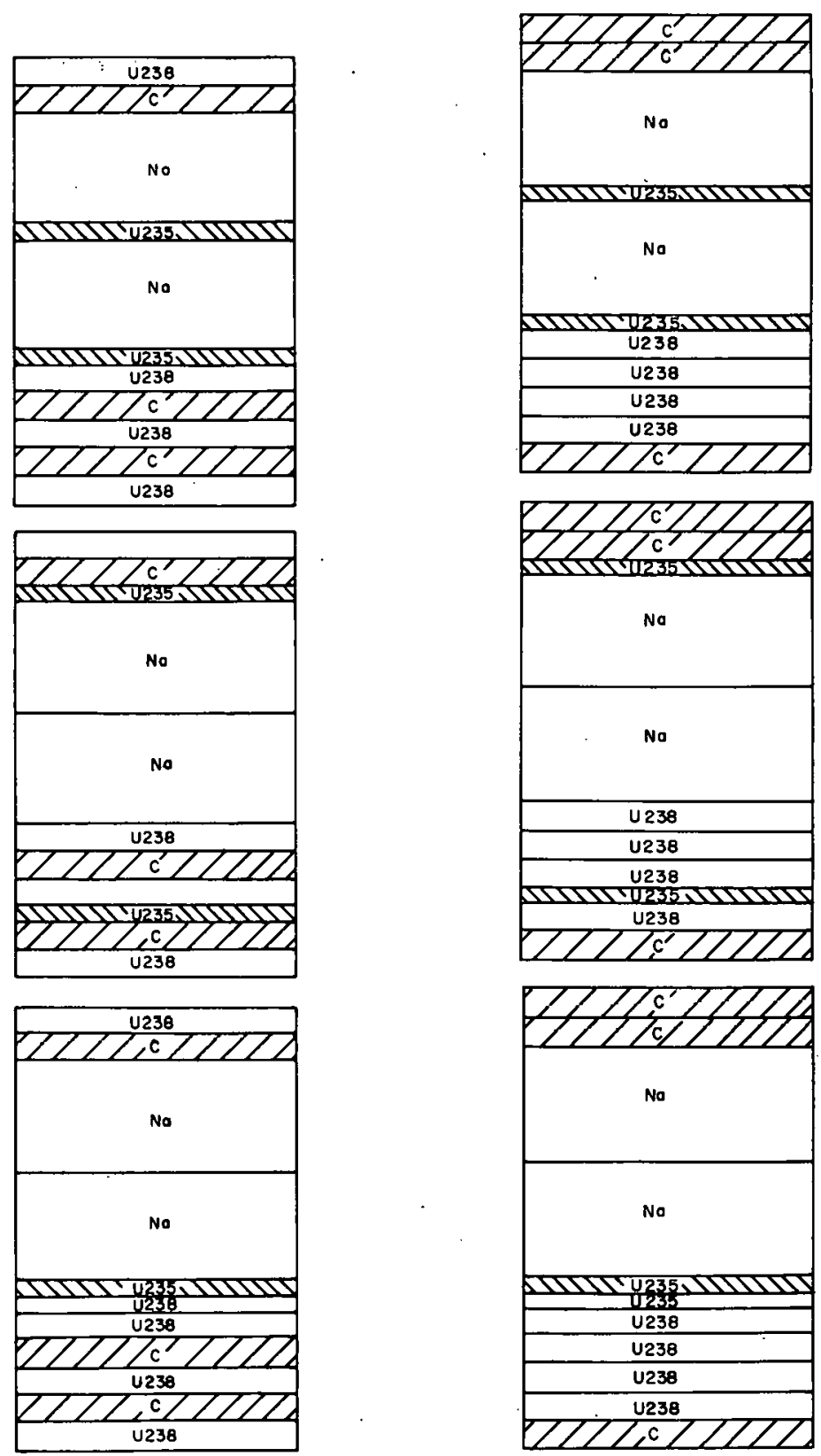

Fig. 6. Reference Loading Pattern of Three-drawer Cell for Bunching $U^{238}$ in Assem bly 5 of ZPR -6
Fig. 7. Pattern for Bunched $U^{238}$ Loading in Three-drawer Cell of Assembly 5 of ZPR-6 
not require any shifting in position of either the $U^{235}$ plates or the sodium cans. It should be noted that the spacing between the $U^{235}$ plates in the threedrawer cell is essentially equidistant. The region in which the loading pattern was changed from that shown in Fig. 5 to that shown in Fig. 6 and finally to that shown in Fig. 7, was a square comprising the central 9 by 9 drawers $(49.72$ by $49.72 \mathrm{~cm}$ ) in each half of the reactor. At a radius of about $20 \mathrm{~cm}$ from the center of this region, there were four control rods per reactor half, equally spaced about the center. The loading pattern of these control rods (or drawers) was the same as that of the central drawer shown in Fig. 5, and this pattern was maintained in all experiments. The number of drawers in which the loading patterns were changed were 77 per reactor half.

a. The Effect of Varying $\sigma$ p of $U^{238}$ on Critical Mass. The reactivity change in the system due to the change in loading pattern from that shown in Fig. 5 to that shown in Fig. 6 was $-13.4 \pm 0.4$ Ih for the 154 drawers involved in both halves. This reactivity decrease may be due to either a slight increase in $\sigma_{\mathrm{p}}$ of $\mathrm{U}^{238}$ relative to the normal loading pattern of Fig. 5 or to an increase in the streaming through the light-density channels of sodium.

The change in pattern loading from the reference case of Fig. 6 to the bunched case of Fig. 7 was carried out in steps. The first step was changing the loading pattern in the 9 central drawers per half (a total of 18 drawers). The second and subsequent steps were bunching the $\mathrm{U}^{238}$ in rings a round the central 9 drawers per half. In Table XIV a re summarized the experimental results. The total increase in reactivity in this region was +131.6 Ih $(0.275 \% \Delta \mathrm{k} / \mathrm{k})$. The experimentally determined decrease in the critical mass that is equivalent to this reactivity increase was $51.6 \mathrm{~kg}$ of $\mathrm{U}^{235}$.

TABLE XIV. Reactivity Change due to Bunching $\mathrm{U}^{238}$ in Assembly 5 of ZPR-6

\begin{tabular}{ccc}
\hline $\begin{array}{c}R_{i}-R_{0} \\
(\mathrm{~cm})^{\mathrm{a}}\end{array}$ & $\begin{array}{c}\text { No. of } \\
\text { Drawers }\end{array}$ & $\begin{array}{c}\text { Reactivity } \\
\text { Change }(\mathrm{Ih})^{\mathrm{b}}\end{array}$ \\
\hline $0-9.35$ & 18 & $+17.5 \pm 0.4$ \\
$9.35-15.85$ & 32 & $+30.6 \pm 0.4$ \\
$15.85-21.95$ & 41 & $+33.6 \pm 0.4$ \\
$21.95-28.45$ & 63 & $+49.9 \pm 0.4$ \\
\hline
\end{tabular}

${ }^{a} R_{i}$ and $R_{0}$ are the equivalent inner and outer radii of cylindrical rings.

$\mathrm{b}$ The bunching in a ring was performed a round a bunched region.

The data shown in 'Table XIV is compared with a $\mathrm{J}_{0}^{2}(2.405 \mathrm{r} / \widetilde{\mathrm{R}})$ distribution in Fig. 8. It is seen that the fit is reasonable over the range of measurements. If it is assumed that the $\mathrm{J}_{0}^{2}$ distribution is reasonable 


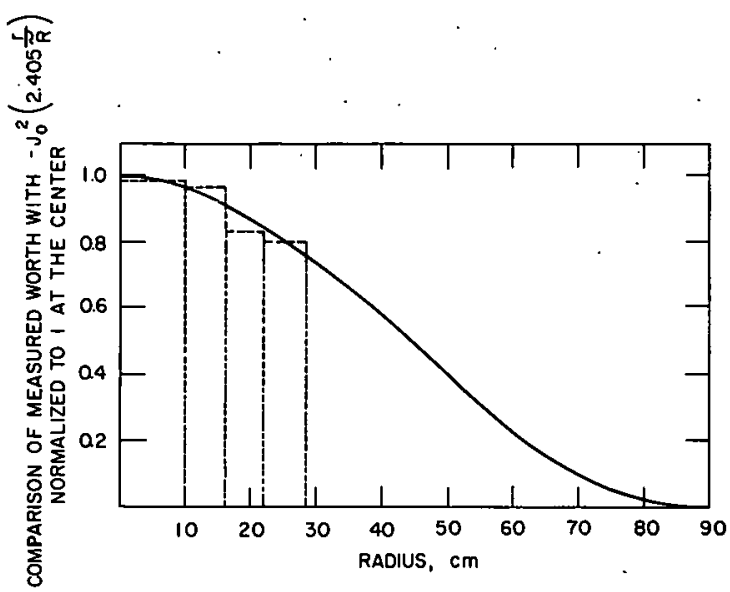

Fig. 8

Extrapolation of the Worth of $\mathrm{U}^{238}$

Bunching in Assembly 5 of ZPR-6

for the entire core, then the extrapolated increase in reactivity due to bunching of $\mathrm{U}^{238}$ is $218 \mathrm{Ih}$. This increase in reactivity corresponds to a $5.6 \%$ decrease in the critical mass $(87.2 \mathrm{~kg})$.

b. The Effect of Varying $\sigma_{\mathrm{p}}$ of $\mathrm{U}^{238}$ on Sodiumvoid Coefficient. The sodium-void coefficient was measured in the central 18 drawers with the loading patterns shown in Figs. 5, 6, 7, and 9. In each case the sodium was removed from the front 4 in., from the front 8 in., and from the entire axial length (28 in.) in each half of the reactor. The difference between the loading patterns in Figs. 7 and 9 is simply that the bunched $U^{238}$ was moved away from the sodium cans by inserting a $1 / 8$-in. plate of graphite between these two materials. The results are given in Table XV. It is to be noted that the difference in the sodium-void coefficient obtained with the loading patterns of Figs. 6 and 7 is mainly due to the decrease in $\sigma_{\mathrm{p}}$ of $\mathrm{U}^{238}$ for the bunched case. Preliminary calculations support this conclusion. The difference between the sodium-void coefficient obtained with the normal loading (see Fig. 5) and that obtained with the reference case (see Fig. 6) cannot be accounted for on the basis of variation in $\sigma_{\mathrm{p}}$ of $\mathrm{U}^{238}$. It is not expected that the value of $\sigma_{p}$ for the loading pattern in Fig. 6 would be lower than that of the normal loading. It is conceivable that the streaming effect in the reference case is more prominent than in the normal loading because the sodium cans in all three drawers of the reference case arebunched. The streaming effect will be investigated shortly.

Fig. 9

Loading Pattern Used in Measuring Sodiumvoid Coefficient in Assembly 5 of ZPR-6

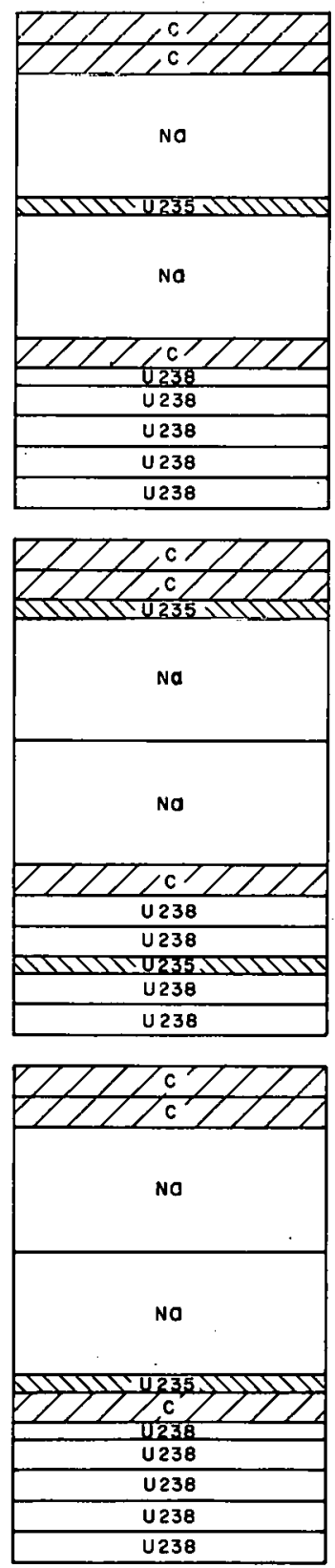


TABLE XV. Dependence of Sodium-void Coefficient on Loading Pattern

\begin{tabular}{|c|c|c|c|}
\hline $\begin{array}{l}\text { Section } \\
\text { Voided } \\
\quad(\mathrm{kg})\end{array}$ & $\begin{array}{l}\text { Sodium } \\
\text { Removed } \\
(\mathrm{kg})\end{array}$ & Loading Pattern & $\begin{array}{c}\text { Reactivity Effect } \\
\text { of Sample (Ih) }\end{array}$ \\
\hline Front 4 in. & $\begin{array}{l}1.772 \\
1.955 \\
1.955 \\
1.955\end{array}$ & $\begin{array}{l}\text { Normal Loading (Fig. 5) } \\
\text { Reference Case (Fig. 6) } \\
\text { Bunched Case (Fig. 7) } \\
\text { Position Effect of Bunching } \\
\quad \text { (Fig. 9) }\end{array}$ & $\begin{array}{r}+2.21 \pm 0.20 \\
+1.51 \pm 0.10 \\
-0.017 \pm 0.30 \\
+0.10 \pm 0.30 \\
\ldots\end{array}$ \\
\hline Front 8 in. & $\begin{array}{l}3.727 \\
3.91 \\
3.91\end{array}$ & $\begin{array}{l}\text { Normal Loading (Fig. 5) } \\
\text { Reference Case (Fig. 6) } \\
\text { Bunched Case (Fig. 7) }\end{array}$ & $\begin{array}{l}+4.11 \pm 0.20 \mathrm{a} \\
+2.70 \pm 0.24 \\
+0.13 \pm 0.20\end{array}$ \\
\hline $28 \mathrm{in.}$ & $\begin{array}{l}13.50 \\
13.62 \\
13.62 \\
13.62\end{array}$ & $\begin{array}{l}\text { Normal Loading (Fig. 5) } \\
\text { Reference Case (Fig. 6) } \\
\text { Bunched Case (Fig. 7) } \\
\text { Position Effect:of Bunching } \\
\quad \text { (Fig. 9) }\end{array}$ & $\begin{array}{r}-3.95 \pm 0.20 \\
-10.17 \pm 0.02 \\
-16.97 \pm 0.03 \\
-17.11 \pm 0.55\end{array}$ \\
\hline
\end{tabular}

a This number is the sum of two adjacent 4 -in. sections.

There was no significant effect on the sodium-void coefficient when the loading pattern of Fig. 7 was replaced by that shown in Fig. 9.

c. Environmental Effect on the Bunching of $U^{238}$ Plates. The environmental effect, which is primarily due to the Dancoff interaction, was investigated by: (i) measuring the reactivity change associated with bunching the $\mathrm{U}^{238}$ in only the central drawer of each half with the surrounding drawers having the loading pattern shown in Fig. 6; (ii) repeating the same measurement with the bunched $U^{238}$ in the surrounding 8-drawer square ring per reactor half; and (iii) performing the same measurement once again with the surrounding 8 drawers unbunched but with a square ring (16 drawers per half) adjacent to the 8 -drawer ring, bunched. This square ring was one drawer away from the central drawer. The reactivity change due to the bunching of the two central drawers alone was $+1.56 \pm 0.08 \mathrm{Ih}$. The reactivity change that resulted from bunching the two central drawers when the surrounding 8 drawers per half were bunched was $+2.02 \pm 0.07$ Ih. The reactivity change that resulted from the last case was $+1.54 \pm 0.07$ Ih. These results show that the effect of bunching of the $U^{238}$ in the 8 drawers per reactor half square ring adjacent to the central drawers increased the reactivity due to the bunching in the two central drawers by about $25 \%$.

Such an effect was totally absent when the bunching was in the ring that was one drawer away from the central drawers. 
The same types of measurements were performed to determine the environmental effects on the sodium-void coefficient in the two central drawers. It was necessary to remove all the sodium from the two central drawers in order to effect a measurable change in reactivity. The effects from the three different environments, described earlier, on the sodiumvoid coefficient were not measurable. Further examination of this phenomenon indicated that the worth of the sodium in the bunched two central drawers was largely due to the leakage component since the spectral component at center, as seen from Table XV, was nearly zero. The environmental effect on the leakage component of the sodium-void coefficient is small (it is a second-order effect) and hence more difficult to measure with the present technique.

The uncertainties in the measured reactivity values are based on the computed variance in the data and the propagation of error. The values reported are the difference in averages of at least two data runs and two reference runs. In some cases when the reproducibility was poor (approx $0.4 \mathrm{Ih}$ ), four or five runs were performed. Interpolation between reference runs to account for what seemed to be systematic reactor drift was not used because the reactivity values were not reproducible within the uncertainty derived from such techniques.

d. The Effect of $\sigma_{\mathrm{p}}$ on Fission and Capture Rates. The effect of varying $\sigma_{\mathrm{p}}$ of $\mathrm{U}^{238}$ on the capture and fission in $\mathrm{U}^{238}$ and fission in $\mathrm{U}^{235}$ was investigated by measuring these quantities in the loading patterns of Figs. 6 and 7. Depleted uranium foils, 5 mils thick by $5 / 8$ in. in diameter, were placed in such a manner that there was a foil next to every side of every plate in the three-drawer cell. The foils were positioned at an axial distance of 2 in. from the center of the core in one half of the assembly. The bottom edges of the foils were touching the stainless steel drawers. Similarly, the $\mathrm{U}^{235}$ foils, 5 mils thick by $3 / 8$ in. in diameter, were placed in the other half of the assembly at a comparable position with respect to the $\mathrm{U}^{238}$ foils from the center of the core. The foils were irradiated for one hour at about $50 \mathrm{~W}$. Five hours after the irradiation the activities of the $U^{238}$ foils were counted as function of time for fission fragments by counting gamma rays with energy of about $0.41 \mathrm{MeV}$ and for capture by counting the $106-\mathrm{keV}$ gamma rays from excited $\mathrm{Pu}^{239}$ in coincidence with $\mathrm{X}$ rays produced by internal $\mathrm{K}$-conversion electrons. The $5-\mathrm{hr}$ waiting period was necessary to allow sufficient time for the buildup of $\mathrm{Np}^{239}$ from $\mathrm{U}^{239}$. The $\mathrm{U}^{235}$ foils were counted as a function of time for fission fragments. After counting, a few foils of each type were radiochemically analyzed for the absolute number of fissions and captures in the $\mathrm{U}^{238}$ foils and for the absolute number of fissions in the $\mathrm{U}^{235}$ foils. The radiochemical results were used in conjunction with the results from the counting techniques to obtain efficiency factors to convert the rest of the data to absolute numbers. The results obtained with the loading pattern of Fig. 7 (bunched case) are reported here. The results obtained with the loading pattern of Fig. 6 a re presently being analyzed. 
Figure 10 shows the absolute fission.rates per gram of $U^{235}$ as a function of position in the three-drawer cells. The relative uncertainty in each point due to the inherent counting statistics is $0.2 \%$. The absolute uncertainty which is based on the statistics of the radiochemical analysis is about $2 \%$. It is noted from Fig. 10 that there are more fissions in the graphite regions than anywhere else and that the fission rates in the bunched $U^{238}$ are at a minimum.

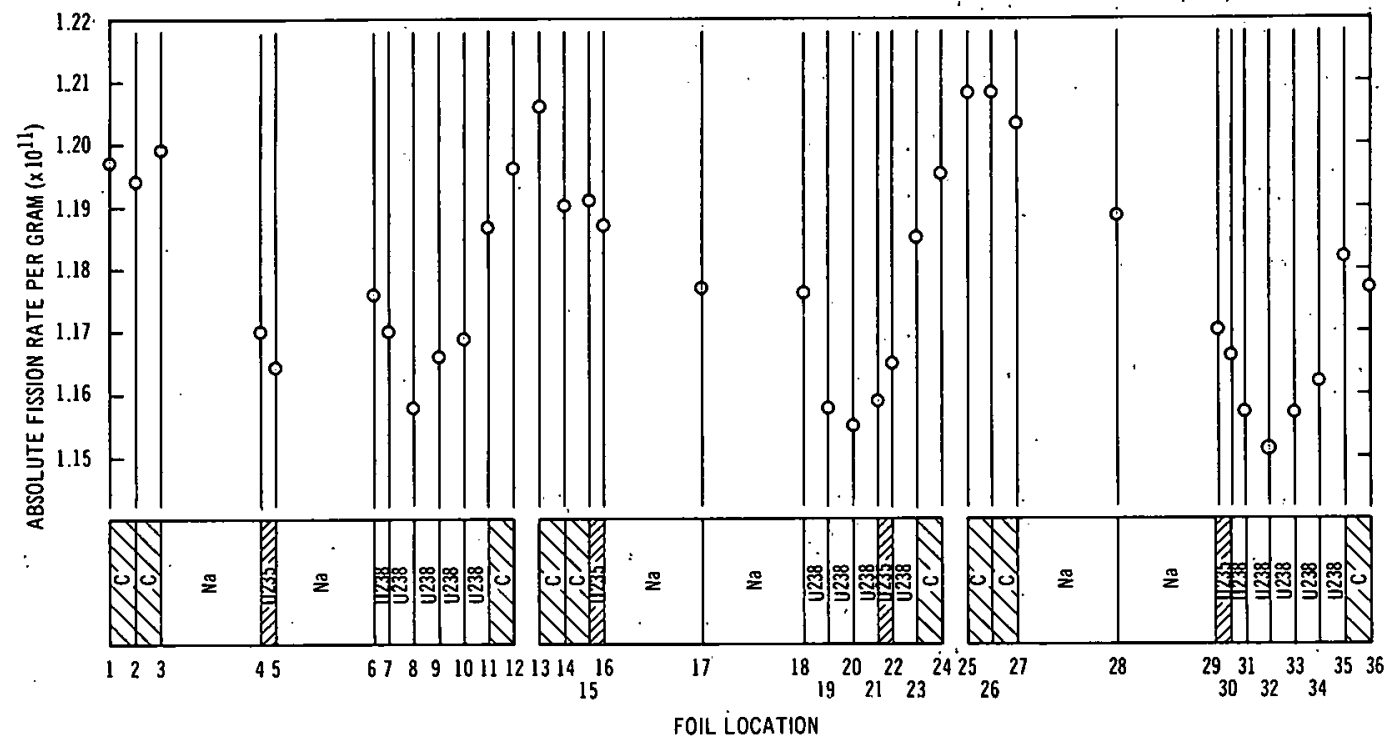

Fig. 10. Absolute Fission Rates per Gram $U^{235}$ in Bunched $U^{238}$ Case of ZPR-6 Assembly 5

Figure 11 shows the fission rates in $U^{238}$ as a function of position. The peaks occur in the vicinity of $U^{235}$ fuel plates.

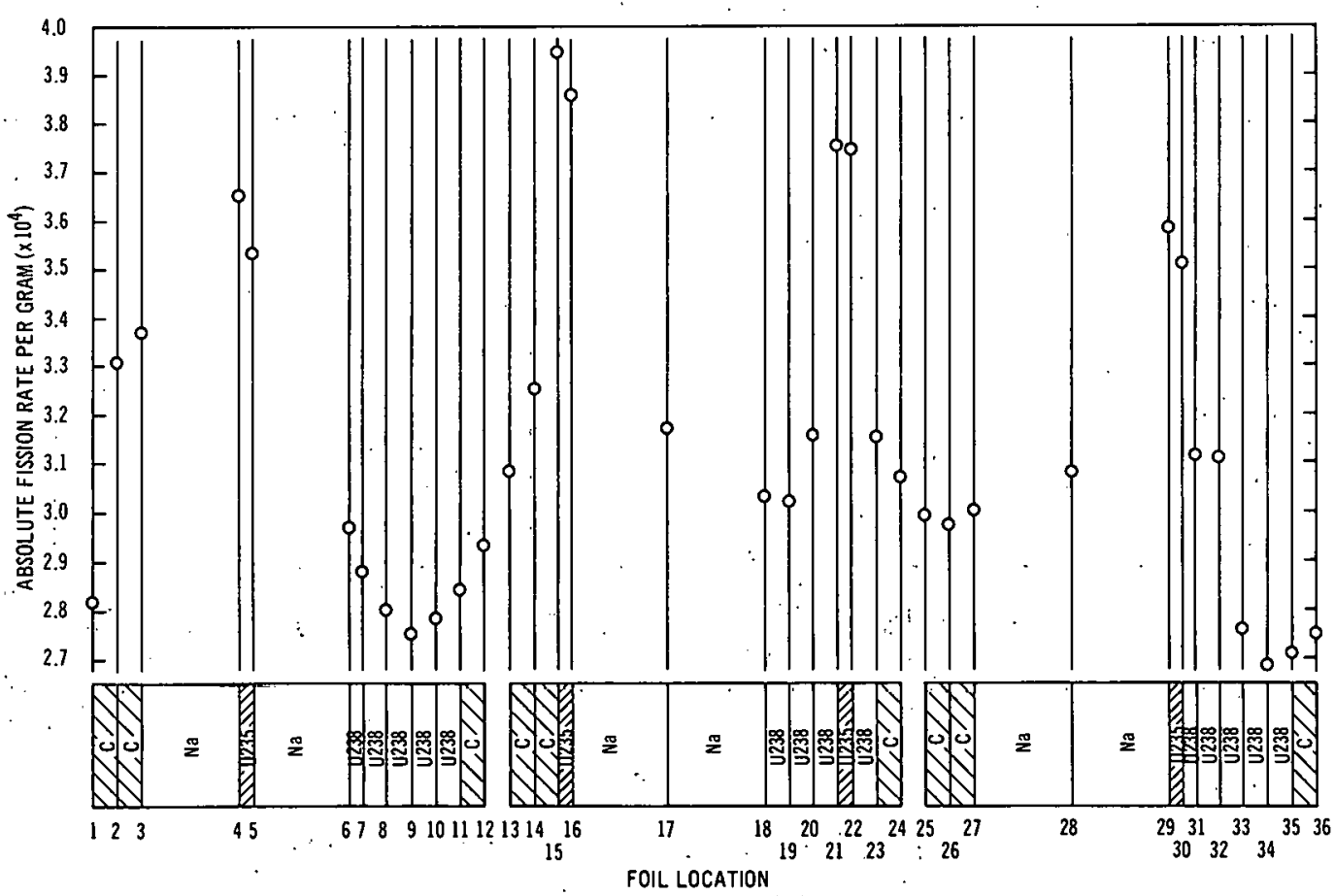

Fig. 11. Absolute Fission Rates per Gram U $U^{238}$ in Bunched $U^{238}$ Case of ZPR- 6 Assembly 5 
Figure 12 shows the absolute capture rates per gram of $\mathrm{U}^{238}$. The size of the flag on the data is due to the error in the absolute measurements. The relative error is typically $0.2 \%$. It is noted from Fig. 10 that there are considerable dips in the capture rates within the bunched $\mathrm{U}^{238}$.

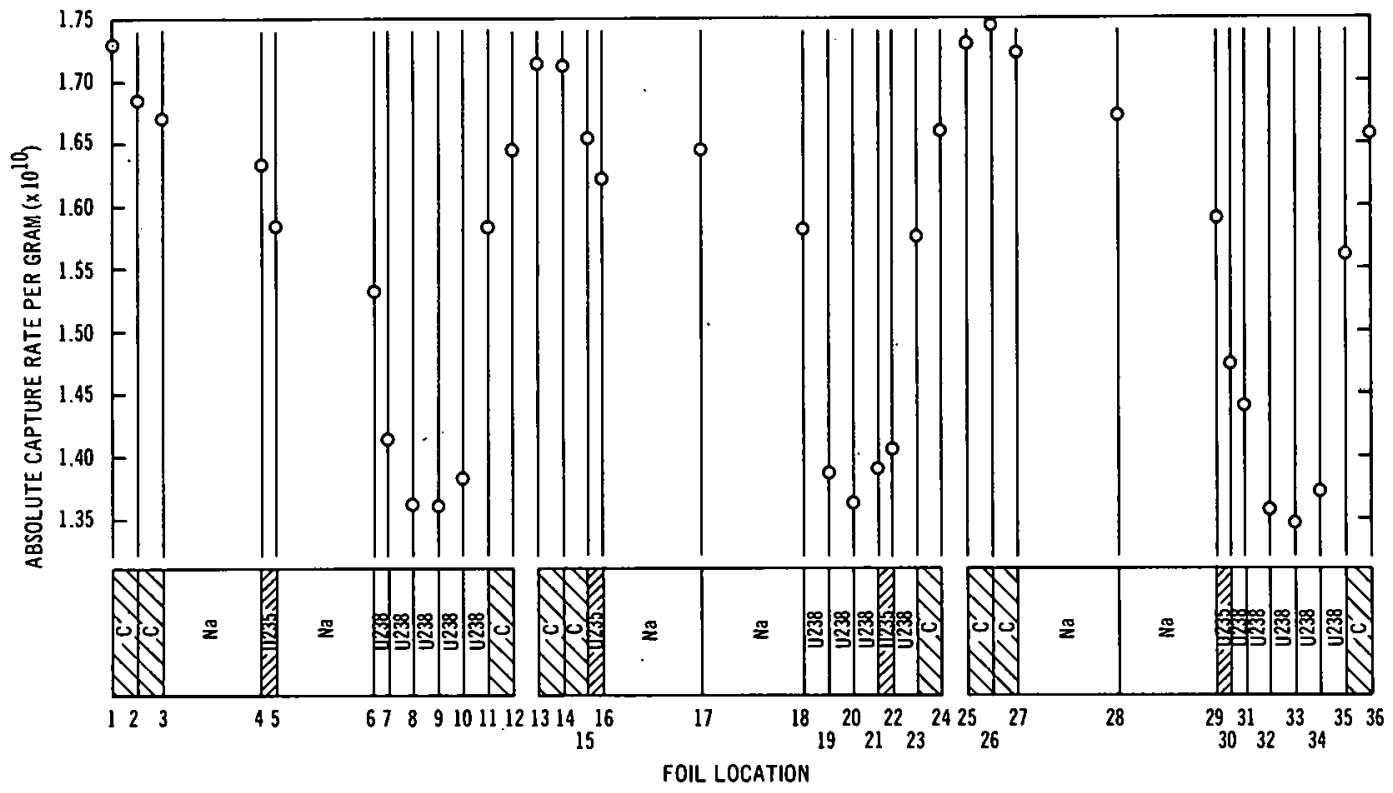

Fig. 12. Absolute Capture Rates per Gram U238 in Bunched U ${ }^{238}$ Case of ZPR-6 Assembly 5

Figures 13 and 14 show the ratios of $U^{238}$ captures to $U^{235}$ fissions and of $U^{238}$ fissions to $U^{235}$ fissions as a function of position, respectively. It is noted that these ratios vary as much as $30 \%$ within the three-drawer cell.

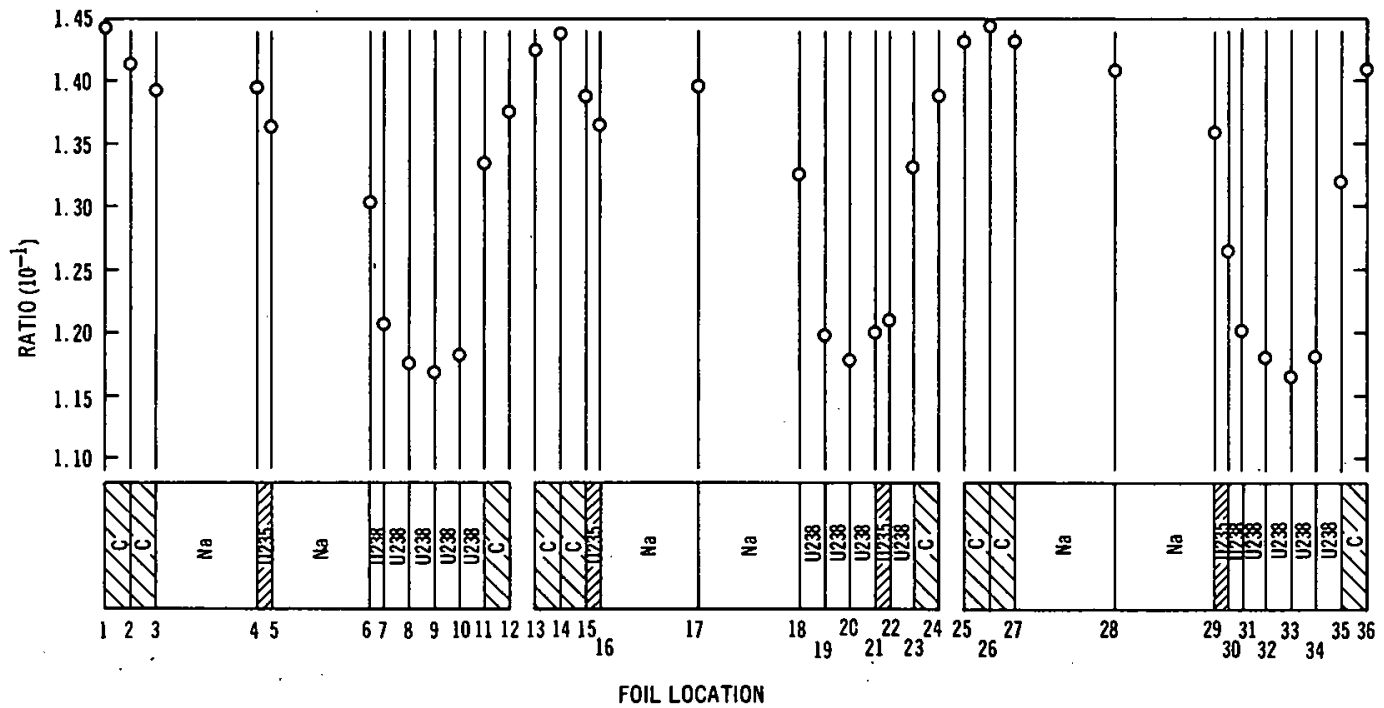

Fig. 13. Absolute Number of $U^{238}$ Captures per $U^{235}$ Fission in Bunched $\mathrm{U}^{238}$ Case of ZPR-6 Assembly 5 


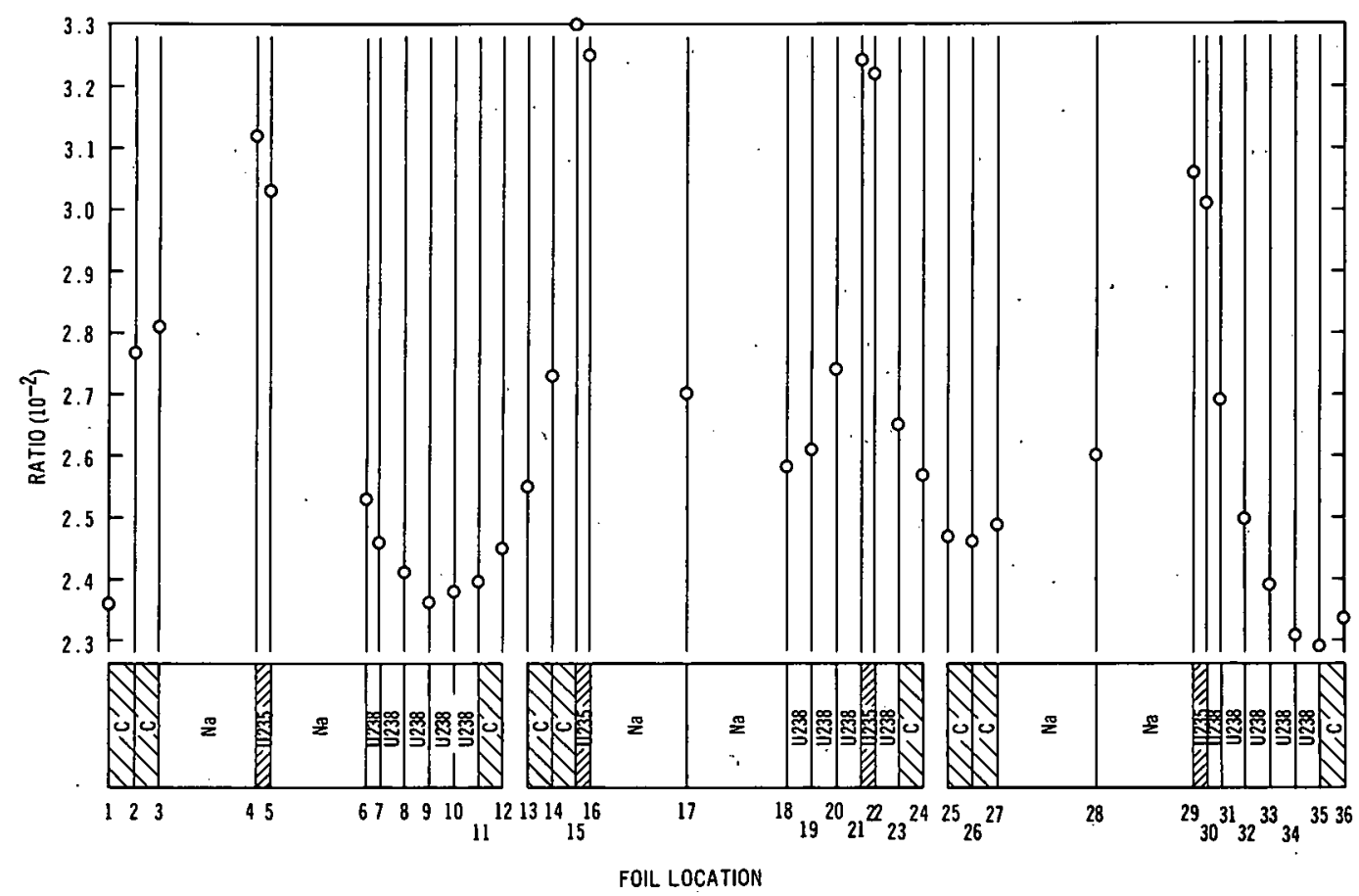

Fig. 14. Absolute Number of $\mathrm{U}^{238}$ Fissions per $\mathrm{U}^{235}$ Fission in Bunched U238 Case of ZPR-6 Assembly 5

3. $\mathrm{ZPR}-9$

Results of Doppler measurements made in Assembly 16, the third in a series of polyethylene-softened assemblies, indicated that a fourth and final assembly should be built to conclude the investigation into the systematics of the $U^{235}$ Doppler coefficient.

In this assembly (Assembly 17) the $10.6 \mathrm{v} / 0$ depleted uranium of Assembly 16 will be replaced with carbon. The final material composition will be $8.7 \mathrm{v} / \mathrm{o}$ polyethylene, $30 \mathrm{v} / \mathrm{o}$ carbon, $42.5 \mathrm{v} / \mathrm{o}$ sodium, $15.1 \mathrm{v} / \mathrm{o}$ stainless steel, and $3.5 \mathrm{v} / 093 \% \mathrm{U}^{235}$ en riched fuel.

Preliminary $\mathrm{U}^{235}$ Doppler measurements have been made in a smallzoned version of the full-size assembly. These results indicate that the $\mathrm{U}^{235}$ Doppler coefficient will be strongly negative in Assembly 17. The fullsize version of Assembly 17 is in the process of being installed on the ZPR-9 machine.

4. ZPPR

The construction contractor has poured the concrete for the cell wall up to. the lower edge of the ring beam. The concrete roof of the fuelstorage vault-workroom interior equipment room area was poured. The reinforcing steel is being placed for the remaining portions of the access corridor, the blanket-storage room, the emergency escape corridor, and 
the connecting corridor to the support wing. The west wall of the support wing has been installed, and work is continuing on the north and south walls. The placing of backfill, wall finish, lighting fixtures, and ventilation ducts is continuing.

The preliminary processing of the sand for the cell roof at the Central Facilities has been completed. The sand has been transported to Idaho Falls for washing and final grading. An additional $30 \mathrm{cu}$ yd are being processed concurrently for the ZPR-6 and ZPR-9 emergency filters.

The wood impact shield has been placed above the bed and tables which are stored in the reactor cell. A fire-detection system is being prepared for installation in the temporary storage area of the bed and tables. The waterproof covering of the bed and tables was removed and the units were inspected for rust, since there has been evidence of free moisture inside the storage structure. The critical areas of the bed and tables appear to be free of corrosion.

The Final Safety Analysis Report is in its final stages of preparation. The accumulation of data and equipment manuals for the operating manual has been started.

The present status of the reactor components which have been received this month or have not yet been received is as follows:

Matrix Drawers. The narrow front and rear drawers have been received and accepted. This completes the matrix drawers.

Poison Rod Drives. The vendor is checking and debugging the as sembled rod drives. An ANL representative is scheduled to visit the vendor the first week of May.

Personnel Shields. The vendor has received all components for the personnel shields except the tractor drives. Assembly of the shield units has begun.

Matrix Alignment. The castings of the alignment plates have been poured. Machining of the first plate has begun.

Source Drives. The source drives have been assembled and checked by the manufacturer. An ANL representative is scheduled to inspect the assembled units at the vendor's plant during the first week of May.

Rod Drive Mounting Plates. Because it was necessary to repour the second plate, the scheduling of machining has been delayed for four weeks. Attempts are being made to reduce this delay. 
Fuel Control Drawers. The purchase order to the new vendor, Stainless Steel Equipment Company of Denver, Colorado, was issued on March 31. Delivery is scheduled for July.

Poison Safety Blade Clevises. The vendor is reworking the clevises.

Boron Fabrication. The vendor is assembling a new furnace capable of the $2000^{\circ} \mathrm{C}$ operating temperature necessary for pressing the boron carbide plates.

Stack Particulate Monitor. The stack monitor has been repaired, checked out, and accepted.

An abbreviated mockup of the ZPPR matrix, using the knees and 5 columns of tubes, 43 tubes high, has been assembled to check the deflections due to core loads. The clamping system performed as designed and deflections of the clamped tubes under load were under $0.010 \mathrm{in.}$ The mockup will also be used to checkout the installation procedures for the rod drives and experimental equipment.

\section{Plutonium Fuel Procurement}

a. Programmatic Requirements. More than $3600 \mathrm{~kg}$ of plutonium is required to measure criticality and neutronic effects in very large reactor assemblies to be built in ZPPR and in ZPR- 6 and ZPR-9. About $2900 \mathrm{~kg}$ of the plutonium are being fabricated as U-28.3 w/O Pu-2.5 w/o Mo alloy plates, which will be jacketed in stainless steel. The plutonium will be $88.3 \%$ fissile $\left(\mathrm{Pu}^{239}+\mathrm{Pu}^{241}\right)$ and $11.5 \% \mathrm{Pu}^{240}$. An additional $200 \mathrm{~kg}$ of plutonium will be derived from highly irradiated fuel compositions. This material, which will contain increased amounts of $\mathrm{Pu}^{238}, \mathrm{Pu}^{240}, \mathrm{Pu}^{241}$, and $\mathrm{Pu}^{242}$, will be fabricated into metal plates, oxide-loaded elements, and instrumented test specimens, which will be used to measure the effect of plutonium isotopic composition. There is an additional requirement for $500 \mathrm{~kg}$ of plutonium containing $11.5 \% \mathrm{Pu}^{240}$ to be manufactured into ( $\left.U, P u\right) \mathrm{O}_{2}$ and (U, $\mathrm{Pu}$ )C pellet-loaded tubes and plates to study light-element dilution effects. These elements may also be used to confirm temperature-related effects, which are also being studied in Doppler effect test elements.

b. Plutonium Ingoting. The critical and neutron effect experiments require fuel of a closely controlled isotopic composition. The plutonium which is available to the program from several different sources varies in composition. The work of blending and ingoting this plutonium to the required isotopic composition is being done under contract with Isochem Inc. at Richland, Washington. Three-kilogram batches of plutonium are being melted and cast into ingots of about one kilogram each. Isotopic and spectrochemical analyses are being furnished with each batch of plutonium blended. A total of $806 \mathrm{~kg}$ of plutonium was blended to $11.50 \pm 0.50 \mathrm{Pu}^{240}$ by 
May 1 , and the analyses were completed on about two-thirds of the material reserved for fabrication at Rocky Flats. An additional $600 \mathrm{~kg}$ of plutonium are being blended during FY 1967, which will be reserved for the first commercial fabrication of the fuel elements. The sampling and ingot identification of this material is being witnessed by an observer from Battelle Pacific Northwest Laboratory.

c. Fuel-element Fabrication. About $300 \mathrm{~kg}$ of plutonium will be required as $\overline{\mathrm{U}-28.3 \mathrm{w} / \mathrm{O} \mathrm{Pu}-25 \mathrm{w} / \mathrm{O} \mathrm{Mo}}$ fuel elements for an experiment scheduled in October-November 1967 and an additional $1100 \mathrm{~kg}$ must be received for ZPPR experiments by March 1968. In order to assure that fuel will be available for these experiments, an order has been placed with the Rocky Flats Division of the Dow Chemical Company for delivery of elements containing $700 \mathrm{~kg}$ of plutonium by May 1967. This company had previously made zero-power reactor elements and the fabrication can start quite quickly. Fabrication is scheduled on a single shift so that, if commercial fabrication should be delayed, the total fuel requirement could be met at Rocky Flats with two- or three-shift production. The planning and setup of fuel-element production equipment was nearly complete by May l, and experimental production of fuel elements is scheduled to begin at Rocky Flats during May 1967. The processes to be used will be essentially those that were developed at ANL, and arrangements have been made for close ANL supervision of the production.

Negotiations have been completed with one commercial source, to establish a contract for part of the alloy fuel-element production, and detailed contract recommendations will be submitted to $\mathrm{AEC}-\mathrm{CH}$ for the commercial fabrication of ZPPR fuel elements during the first week in May.

The plutonium alloy plates are jacketed in rectangular-section, stainless steel sleeves with welded end plugs. Vacuum-melted, Type 304L stainless steel has been fabricated into 1.350-in.-dia x 0.016-in.-wallthickness tubing by Pacific Tube Company. Nine-hundred feet of this tubing were inspected by ANL representatives and approved for shipment to ANL. Difficulty was experienced in obtaining a commercial source for the forming of jacket sleeves to ZPPR tole rance requirements. Production tooling for stretch forming this tubing into rectangular sleeves has been completed in ANL shops, and an order has been placed for the first 8000 jacket sleeves, which will be used for the immediate requirement and will serve to demonstrate to commercial fabricators that the jacket sleeves can be fabricated as specified. The end plugs are being cut from precision-formed rectangular wire drawn by Major Wire Company. 


\section{Other Fast Reactor Physics}

\section{Plutonium Air Monitor for Use in ZPR Areas}

A plutonium air monitor has been designed which utilizes the high sampling rates of the impactor monitor ${ }^{2}$ and has the pulse-height discrimination advantages of low-sampling-rated filtration monitors. ${ }^{3}$ In the new. design the dust is impacted directly onto the face of a $2 \pi$ passivated solidstate detector. ${ }^{4}$ Alpha emissions due to plutonium are discriminated from those due to radon-thoron daughter products or due to uranium by a singlechannel analyzer. A second channel is used to follow the higher-energyalpha emissions of the radon-thor on daughter products so that background corrections are made in the plutonium measurement.

The dust accumulation on the solid-state detector is removed by wiping once a day or more frequently. A thin film of grease is used on the detector face to cause the impacted particles to adhere. No degradation in resolution has been encountered after two weeks of initial "life" tests, and there is nothing that would indicate such degradation would be expected in the near future. "Life" tests are continuing.

\section{Component Development}

1. Sodium Technology and Development

a. Fission-gas Pressure Transducer. To obtain an indication of the fission-gas pressure buildup in individual fuel pins while they are operating in the reactor, commercially available pressure transducers are being reviewed and evaluated for conditions expected in the Fast Flux Test Facility (FFTF), and will be tested out-of-pile and in-pile.

(i) NaK-filled Capillary System. A prototype transmitter of this type was built and tested. It has a 0.5 -in.-dia stainless-steel welded bellows welded to a $1 / 8$-in.-OD by $1 / 16$-in. - ID $20-\mathrm{ft}$-long capillary tube leading to a 300-psi pressure transducer. The system was evacuated at the transducer end and backfilled with $\mathrm{NaK}$; the bellows end was sealed in a pressure chamber supplied with 150-psig argon.

The 20-ft capillary tube was wound in a 2.5-ft dia coil; a system curve of voltage output from the transducer to gauge pressure was generated. The tube then was unwound and another test curve was obtained. The two curves checked, indicating that bends in the capillary tube did not affect accuracy.

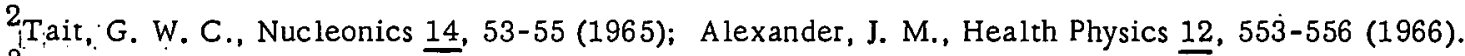

${ }^{3}$ Phillips, W. A., and Lindeken, C. L., Health Physics 9. 299 (1963); Hazards Control Quarterly Report 4. 10-15, UCRL-14351 (1965).

${ }^{4}$ Simtec, Ltd., 3400 Metropolitan Blvd. East, Montreal 38, Canada, $200 \mathrm{~mm}^{2}$ and $500 \mathrm{~mm}^{2}$. 
The pressure chamber containing the bellows was placed in a furnace and heated to $1200^{\circ} \mathrm{F}$. System thermal-expansion effects showed a new positive pressure on the transducer of $0.2 \mathrm{mV}$. Although the exact curve of this zero shift versus temperature has not been obtained yet, the data indicated that $8 \mathrm{mV}$ is worth $100 \mathrm{psi}$. Therefore, on a linear scale, $0.2-\mathrm{mV}$ zero shift is equivalent to $2.5 \mathrm{psig}$. A $9-\mathrm{ft}$ length of capillary tube will be heated to $1200^{\circ} \mathrm{F}$ to determine effect on calibration.

The bellows end has been heated to $1200^{\circ} \mathrm{F}$ many times; the consistency of voltage output versus pressure is very encouraging and indicates that accuracy can be within $\pm 1 / 4$ psig. Temperature effects are not serious if the working range of bellows temperature is known.

This system can be miniaturized to a $1 / 4-$ in. bellows. Smaller size would be quite difficult because of the $\mathrm{NaK}$ expansion effects and the inability of the bellows to expand sufficiently. Thus, if accuracy is to be maintained despite limited bellows expansion, when a smaller bellows is used, the capillary tube must be smaller also. For diameters less than 1/4 in., electrodeposited bellows made of stainless steel are not available; they probably would have to be made of nickel. Further investigation is underway.

(ii) Strain-gauge Systems. Work has continued on the Statham Model-PA81 2 thin-film transducer (see Progress Report for February 1967, ANL-7308, p. 23): Examination of the bridge portion indicates the the gold wire was in almost intimate contact with the header support, which probably was what caused the insulation resistance to drop to $\sim 3$ kilohms. When the wires were reoriented again, the insulation resistance increased to over 200 megohms. A deposit of gold was noted on and near the header-pin support.

The transducer bridge has been reconnected to the lead wires, and tests of the bridge will continue above $600^{\circ} \mathrm{F}$ to determine whether the sagging wires were, in fact, the: cause of the previously observed permanent change in insulation resistance. During the previous tests, no increase in bridge resistance was measured, thus indicating little, if any, oxidation. Any evidence of strain-element oxidation will be observed by continuously checking the bridge resistance as well as the insulation resistance.

b. Failed-fuel Locator. To find a method for determining which subassembly within a shutdown reactor core has one or more failed fuel pins, the feasibility of sensing the fission-gas release from the subassembly is being investigated. To prove the principle, a scheme will be demonstrated for efficiently disengaging noble gases from a continuously circulating liquid-sodium system at $1200^{\circ} \mathrm{F}$. The equipment will include devices for disengaging the gas, trapping sodium vapor, viewing, monitoring radiation, and for injecting gas. 
Work has continued on modifications to an existing. sodium vaportrap flow system (see Progress Report for February 1967., ANL-7308; pp. 23-24) that will be used to evaluate methods for detecting small quantities of simulated fission-product gas. The sodium-supply tank was filled with sodium, new heaters were installed, and new insulation was applied; temperature-control wiring remains to be installed.

The literature is being surveyed to gain a better understanding of the adequacy and operability of previously designed methods for detecting and locating failed fuel cladding. For liquid-cooled reactors, most such detectors must contend with interference radiation from corrosion products, coolant impurities, system contaminants, and the coolant itself, which tend to mask the signal being sought. A considerable portion of most such detector systems is devoted to the reduction of the undesirable background radiation by means such as delay lines, ion exchanges, gaseous-fission-product stripping from liquid coolants, electrostatic precipitation, and gas chromatography, coupled with energy discrimination or spectrographic analysis of the output from a wide variety of detection instruments.

c. Signal Lead Connector. To develop remote connectors for electrical and fluid signal leads for in-core instrumentation, connector leadwire assembly designs and test procedures will be reviewed, changes made to meet FFTF design criteria, new connector concepts considered, out-ofpile test programs established, and methods for terminating the sensor leads inside the reactor vessel, both above and within the sodium, will be studied and developed.

The rebuilt test tank and associated equipment have been checked out and made operational. Performance appears satisfactory; difficulties in sodium transfer, system tightness, and repeatable measurements have been overcome. A prototype connector assembly is being tested. The test con-. sists, mainly, of cycling temperature between 250 and $600^{\circ} \mathrm{C}$ while the connector is submerged continually in sodium. Leakrates have been measured at various temperatures; it appears that a correlation between leakrate and rate of change of temperature can be established. While the leakrate averages about $2 \times 10^{-2} \mathrm{std} \mathrm{cm}^{3}$ of argon/sec, variations ranged up to about twice this value during the first 7 days of this test.

d. In-core Flowmeter. So that sodium flow through individual. subassemblies or process tubes can be measured, technology is being established to assure that small magnetic, turbine, or other types of flowmeters can be obtained for use in severe temperature and radiation environments. Performance and reliability will be demonstrated in out-of-pile and in-pile tests. 
(i) Thermal and Mechanical Tests of Magnet Materials. Thermal tests of the initial Alnico-Vrod magnet having a length-to-diameter ratio of 6 have continued (see Progress Report for February 1967 , ANL-7308, pp. 24-25, and for March 1967, ANL-7317, p. 48); this magnet is designated as sample A5-1. It has accumulated more than $1100 \mathrm{hr}$ at $1200^{\circ} \mathrm{F}$ and there is now a definite indication that the magnetic flux has departed from the initial value; the exact cause of the change remains to be determined.

Most of the Alnico-V and some of the Alnico-VI and -VIII rod magnets for the out-of-pile and in-pile tests have been delivered, so tests can proceed to determine the irreversible and material effects at temperatures up to $1200^{\circ} \mathrm{F}$ for these magnets having various length-todiameter ratios. The change in the shape of the hysteresis loop due to material effects in these alloys will also be determined at room temperature.

So that reversible changes in magnet properties can be measured continuously at high temperatures by use of a magnetometer, a turntable has been designed to swing the test furnace, with the magnet inside, slowly and smoothly through $180^{\circ}$, thus providing two tests positions. The furnace apparatus is being fabricated.

Five magnet manufacturers were requested to quote on supplying typical flowmeter magnets of cast Alnico-VI and -VIII alloys. Only one quotation for Alnico-VI was received; all five vendors declined to quote on the Alnico-VIII magnets. Two vendors who gave reasons for declining to quote cited orientation and wall thinness for the length; another vendor declined because of the small quantity involved. Further discussions are underway to learn whether there is a configuration of Alnico-VIII that can be manufactured suitable for flowmeter application.

(ii) Magnetic Flowmeter Prototype. The preliminary prototype permanent-magnet flowmeter has been installed in the calibration loop and the loop has been made operational. Preliminary flowmeter calibrations have begun in preparation for tests of signal long-term stability.

(iii) Magnet Irradiation Tests. The capsule configuration for irradiating rod magnets in EBR-II has been designed. Sample temperatures of $1200^{\circ} \mathrm{F}$ can be achieved easily; thermal-radiation shields in the capsules will be used to adjust sample temperature to desired levels. To determine sample test temperatures, wires having selected melting points will be installed in the capsules. Rod magnets are being encapsulated in stainless steel cans, and stabilization of the Alnico-V magnets is about to commence. In addition to the magnet samples, specimens of Type 304 stainless steel will be irradiated in some capsules to determine magnetic changes caused by the combined radiation and high-temperature environment. 
e. Fuel-pin Thermocouple. Thermocouples are being developed to indicate fuel-pin temperatures up to $2800^{\circ} \mathrm{C}$. For this development, previous experience with fuel-pin thermocouples has been evaluated, technology is being established to assure satisfactory design and performance, thermocouple assemblies and materials will be tested and evaluated extensively, both out-of-pile and in-pile, and thermocouple-fabrication techniques and specifications will be formulated.

The spectrochemical analysis of the $99.9 \%$-vitrified thoria insulators shows that purity is satisfactory. Coaxial resistivity probes have been assembled with these insulators and tantalum electrodes; preparations have been made to measure the resistivity of the vitrified thoria in a high-temperature furnace.

Bare-wire $\mathrm{W}-3 \% \mathrm{Re} / \mathrm{W}-25 \% \mathrm{Re}$ thermocouples have been assembled for long-term tests of thermoelectric stability in the high-temperature furnace.

For study of the compatibility. of tantalum and $\mathrm{W}-25 \% \mathrm{Re}$ with $\mathrm{UO}_{2}$, the capsule (designated $\mathrm{TU}-1$ ) that had been tested previously (see Progress Report for March 1967, ANL-7317, p. 49) at $2000^{\circ} \mathrm{C}$ for $\sim 33 \mathrm{hr}$ is being examined metallographically. An identical tantalum capsule designated TU-2, has been assembled and is being tested in a l-spig dryhelium environment at $2400^{\circ} \mathrm{C}$; the exposure goal is $720 \mathrm{hr}$.

\section{Liquid Sodium Coolant Chemistry}

a. Dispersion of Carbon in Liquid Sodium. In connection with the studies of the mechanism of carburization and decarburization of metals in liquid sodium, efforts to prepare dispersions of carbon in liquid sodium are continuing. ${ }^{5}$ Carbon-sodium pastes are being prepared, since the carbon in such pastes has been wet by the liquid sodium and wetting of the carbon is considered to be a prerequisite to achieving stable dispersions. A minimum temperature of $\sim 370^{\circ} \mathrm{C}$ was found to be necessary for liquid sodium to wet 90- $\AA$ carbon black.

A carbon-sodium paste with the nominal composition $9.5 \mathrm{w} / 0$ carbon was prepared by adding $90-\AA$ carbon black $(7.4 \mathrm{w} / 0$ oxygen) to liquid sodium at $\sim 450^{\circ} \mathrm{C}$. Samples of the paste were taken through $5 \mu-$ porosity stainless steel filters. Analysis of the samples showed no significant concentration of carbon and, therefore, that the $90-\AA$ particles had agglomerated. Reduction of the oxygen content of the carbon black to $0.3 \mathrm{w} / \mathrm{o}$ (by vacuum-heating) did not alter the results.

\footnotetext{
${ }^{5}$ For previous reports, see Reactor Development Program Progress Reports for January 1967, ANL-7302, p. 41; November 1966, ANL-7,279, p. 20; September 1966, ANL-7255, p。 25.
} 
Portions of a sodium-carbon paste were added to a large batch of sodium (final nominal composition $\sim 740$ ppm carbon) being stirred at $\sim 1000 \mathrm{rpm}$ in a blendor at $150^{\circ} \mathrm{C}$. The stirrer speed was increased to 14,000 rpri during several mixing periods, after each of which the mixture was allowed to settle for about 5 to. $10 \mathrm{~min}$ and then sampled. Analysis of the samples for carbon showed that the. agglomerated particles had not been dispersed. The mixture was allowed to settle for $28 \mathrm{hr}$ during which it was sampled periodically. From the carbon analyses and calculations based on the rate of sedimentation, it is concluded that the carbon agglomerates were $\geq 10 \mu$ in diameter.

\section{E. Fuel Development}

\section{Metal Fuels}

a. Irradiation of Uranium-Plutonium Alloys. Neutron radiographs of two elements, fueled with U-15 w/o Pu-10w/o Zr and with U-15 w/o Pu$10 \mathrm{w} / \mathrm{o} \mathrm{Ti}$ in separate jackets of $\mathrm{V}-20 \mathrm{w} / \mathrm{o} \mathrm{Ti}$. (s see Progress Report for March 1967, ANL-7317, p. 50), indicated fuel-pin elongations of 3.6 and $8.8 \%$, respectively, after irradiation in EBR-II to about 5 a $/ 0$ burnup at maximum jacket temperatures of $540^{\circ} \mathrm{C}$. Although both fuel jackets appeared intact, nearly one-fourth of the elongation of the titanium-bearing fuel was around and above the lower part of the upper fuel restrainer.

Accordingly, fuel pins of U-15 w/o Pu-10 w/o $\mathrm{Zr}$ only were jacketed and were being encapsulated for irradiation to higher burnups. Known as Group M-3 elements, the jacketed fuels, fifteen in number, have now been encapsulated and delivered to EBR-II. The several jacket materials are $\mathrm{V}-20 \mathrm{w} / 0 \mathrm{Ti}$, Type 304 stainless steel, and Type 316 stainless steel. These elements will be irradiated along with four encapsulated EBR-II Mark-IA production fuel elements (the total makes up a full experimental subas sembly).

The M-3 elements are similar to the XA07 elements, which were irradiated to $4.6 \mathrm{a} / \mathrm{o}$ burnup. The contemplated reactor exposure of the M-3 Group will result in maximum jacket temperatures near $600^{\circ} \mathrm{C}$.

Group M-3 will be removed at 10 a/o burnup, but the Mark-IA fuel will operate at jacket temperatures near $500^{\circ} \mathrm{C}$ and will be removed at $3 \mathrm{a} / \mathrm{o}$ burnup. Table XVI lists the specimen and jacket dimensions of Group $\mathrm{M}-3$. 
TABLE XVI. Group M-3 Specimen and Jacket Dimensions

Fuel Material: U-15 w/o Pu-10 w/o Zr (93\%) enriched

Fuel Dimensions: 13.5 in. $x 0.144$ in. in diameter

\begin{tabular}{|c|c|c|c|c|c|c|}
\hline \multirow{2}{*}{$\begin{array}{c}\text { Capsule/Specimen } \\
\text { Number }\end{array}$} & \multicolumn{3}{|c|}{ Cladding } & \multirow{2}{*}{$\begin{array}{l}\text { Specimen } \\
\text { Length } \\
\text { (in.) }\end{array}$} & \multirow{2}{*}{$\begin{array}{l}\text { Plenum } \\
\text { Length } \\
\text { (in.) }\end{array}$} & \multirow{2}{*}{$\begin{array}{l}\text { Specimen Plenum } \\
\text { Volume (cc) (RT) }\end{array}$} \\
\hline & Material & ID (in.) & Wall (in.) & & & \\
\hline ANL-BA-01 & 304 SS & 0.166 & 0.015 & 33.00 & 17.97 & 6.51 \\
\hline ANL-BA-02 & 304 SS & 0.166 & 0.015 & 33.00 & 17.97 & 6.51 \\
\hline ANL-BA-03 & 304 SS & 0.166 & 0.015 & 33.00 & 17.97 & 6.51 \\
\hline ANL-BA-04 & 304 SS & 0.166 & 0.015 & 33.00 & 17.97 & 6.51 \\
\hline$A N L-B A-05$ & 304 SS & 0.166 & 0.015 & 32.61 & 17.57 & 6.36 \\
\hline$A N L-B B-01$ & $304 \mathrm{SS}$ & 0.166 & 0.020 & 29.80 & 14.76 & 5.35 \\
\hline$A N L-B C-01$ & $316 \mathrm{SS}$ & 0.166 & 0.015 & 33.00 & 17.97 & 6.51 \\
\hline ANL-BC-02 & $316 \mathrm{SS}$ & 0.166 & 0.015 & 33.00 & 17.97 & 6.51 \\
\hline ANL-BC-03 & $316 \mathrm{SS}$ & 0.166 & 0.015 & 33.00 & 17.97 & 6.51 \\
\hline ANL-BD-03 & $\mathrm{V}-20 \mathrm{Ti}$ & 0.166 & 0.015 & 24.68 & 9.65 & 3.49 \\
\hline ANL-BD-04 & $\mathrm{V}-20 \mathrm{Ti}$ & 0.166 & 0.015 & 24.68 & 9.65 & 3.49 \\
\hline ANL-BD-05 & $\mathrm{V}-20 \mathrm{Ti}$ & 0.166 & 0.015 & 24.68 & 9.65 & 3.49 \\
\hline ANL-BE-01 & $\mathrm{V}-20 \mathrm{Ti}$ & 0.166 & 0.015 & 22.70 & 7.67 & 2.77 \\
\hline$A N L-B E-02$ & $\mathrm{~V}-20 \mathrm{Ti}$ & 0.166 & 0.015 & 22.70 & 7.67 & 2.77 \\
\hline ANL-BE-03 & $\mathrm{V}-20 \mathrm{Ti}$ & 0.166 & 0.015 & 22.70 & 7.67 & 2.77 \\
\hline
\end{tabular}

2. Carbide Fuels

a. Compatibility of (U,Pu) Carbides with Potential Jacket Materials

(i) ( $U, P u)$ Carbides versus Hastelloy-X. No reaction was observed between Hastelloy-X and $\left(\mathrm{U}_{0.8} \mathrm{Pu}_{0.2}\right) \mathrm{C}$ after heat treatment at $700^{\circ} \mathrm{C}$ for $4000 \mathrm{hr}$. Hastelloy-X and a hyperstoichiometric U,Pu)C composition containing approximately $20 \mathrm{v} / \mathrm{o}(\mathrm{U}, \mathrm{Pu})_{2} \mathrm{C}_{3}$ form a reaction zone $4 \mu$ in depth. The $4 \mu$ average reaction zone consists of a $2 \mu$ nickel-rich zone on the fuel side of the interface plus a $2 \mu$ chromium-rich zone on the jacket side. Although these zones are too small for quantitative analysis, the nickel-rich zone is very probably the compound ( $\mathrm{U}, \mathrm{Pu}) \mathrm{Ni}_{5}$, identified by electron microprobe analysis in a couple containing hyperstoichiometric (U, $\mathrm{Pu}) \mathrm{C}$ versus Inconel $625.6 \mathrm{UNi}_{5}$ has been shown to be the principal product formed in a diffusion couple of $\mathrm{UC}$ versus $\mathrm{Ni} .^{7}$ The extent of reaction was equal to that observed previously (see Progress Report for June 1966, ANL-7230, pp. 17-18) at this temperature for $1000 \mathrm{hr}$.

Another test involving Hastelloy-X with a (U,Pu) carbide composition containing $6.75 \mathrm{w} / \mathrm{o}$ equivalent carbon and consisting of approximately $90 \mathrm{v} / 0(\mathrm{U}, \mathrm{Pu})_{2} \mathrm{C}_{3}$ substantiates the finding that the sesquicarbide phase is the only phase that has reacted in the $700^{\circ} \mathrm{C}$ tests of hyperstoichiometric $(\mathrm{U}, \mathrm{Pu}) \mathrm{C}$. Examination of a compatibility couple containing this

\footnotetext{
${ }^{6}$ ANL Metallurgy Division Monthly Report, March 1967, pp. 55-56.

${ }^{7}$ Anselin, F., Colais, D., and Passefort, J. C., Etude du Diagramme Ternaire Uranium-Carbone-Nickel, CEA-R 2845 (Aug 1965).
} 
composition and heat treated for $1000 \mathrm{hr}$ revealed a $4 \dot{\mu}$ reaction layer and also an adjacent $8 \mu$ layer in the fuel that.was reduced from sesquicarbide to monocarbide. This observation provides an explanation, in the case of the hyperstoichiometric carbide composition, for (1) no increase in the size of the reaction zone after $4000 \mathrm{hr}$ as compared with $1000 \mathrm{hr}$, and (2) the absence of sesquicarbide grains at the Hastelloy-X interface, since these grains were all less than $10 \mu$ in diameter.

(ii) $\left(\mathrm{U}_{0.8} \mathrm{Pu}_{0.2}\right) \mathrm{Fe}_{2}$ versus Type 304 Stainless Steel. Although iron additions to hypostoichiometric UC are reported ${ }^{8}$ to result in improved compatibility with stainless steel through reaction with the excess uranium metal phase to form $\mathrm{UFe}_{2}$, no direct compatibility test with this compound has been reported.

Altempts to fabricate $\left(\mathrm{U}_{0.8} \mathrm{Pu}_{0.2}\right) \mathrm{Fe}_{2}$ pellets were previously reported (see Progress Report for November 1966, ANL-7279, p. 27). After recrushing and repressing these pellets, and firing at $1100^{\circ} \mathrm{C}$, an average geometrical density of $9.45 \mathrm{~g} / \mathrm{cm}^{3}(72 \%$ of theoretical) was obtained; this was approximately equal to that of the earlier work. The pellets were essentially single-phase; chemical analysis showed a slight excess $(0.4 \mathrm{w} / \mathrm{o})$ of iron over that required for stoichiometry, and metallography revealed a small amount of second phase appearing as discrete particles.

Some reaction with the tungsten setter plate was observed. An unidentified phase was found in the tungsten to a depth of $245 \mu$ in the $(\mathrm{U}, \mathrm{Pu}) \mathrm{Fe}_{2}$.

After grinding the ends of the pellets to remove the reaction product, this material was held in contact with Type 304 stainless steel at $800^{\circ} \mathrm{C}$. After $1000 \mathrm{hr}$, only a small layer of about $2 \mu$ was observed at the interface.

b. Performance Studies of Mixed-carbide Fuel. Postirradiation examination of three mixed-carbide elements continued in the Metallurgy Alpha-Gamma Hot Cell (see Progress Report for March 1967, ANL-7317, pp. 54-55). An additional 15 elements remained in EBR-II for continued irradiation.

Metallographic examination continued with the sectioning and preparation of element No. SMV-1. In contrast to the sintering behavior in solid-solution (U-20 w/o Pu) in element No. VMV-1, the physically mixed $\mathrm{UC}-20 \mathrm{w} / \mathrm{O} \mathrm{PuC}$ in element. No. SMV-1 exhibited no indications of sintering even in the hottest area of the fuel column. At a location in VMV-l comparable to the maximum temperature in SMV-1, the sintered diameter of solid-solution fuel was approximately $0.078 \mathrm{in}$. or $30 \%$ of the diameter of the fuel.

8 Herbst, R. J., and Jordan, K. R., Compatibility of Modified Monocarbide Fuels with Stainless Steel, Trans. Am. Nuc. Soc. p. 17 (June 1966). 
Fission-product gas release from the solid-solution (irradiation sintered) fuel in VMV-1 was smaller than that from the physically mixed fuel in SMV-1. Preliminary results were reported in ANL-7317. Values corrected for analytical results are as in Table XVII.

TABLE XVII. Fission-gas Release from Mixed-carbide Fuel

\begin{tabular}{|c|c|c|c|c|}
\hline $\begin{array}{l}\text { Specimen } \\
\text { Number }\end{array}$ & Fuel Description & $\begin{array}{l}\text { Gas Release (\% } \\
\text { of Theoretical) }\end{array}$ & $\begin{array}{c}\text { Max Est } \\
(\mathrm{kW} / \mathrm{ft})\end{array}$ & $\begin{array}{l}\text { Burnup } \\
(\mathrm{a} / \mathrm{o})\end{array}$ \\
\hline SMP - 1 & $\begin{array}{l}\text { Solid solution, } \\
\text { pellets }\end{array}$ & 4.1 & 18.9 & $2.1^{\mathrm{a}}$ \\
\hline VMV - 1 & $\begin{array}{l}\text { Solid solution, } \\
\text { vibratory compacted }\end{array}$ & 8.6 & 29.5 & 3.02 \\
\hline SMV - 1 & $\begin{array}{l}\text { Physically mixed, } \\
\text { vibratory compacted }\end{array}$ & 13.4 & 25.3 & 2.59 \\
\hline
\end{tabular}

A continuous profilometer scan of the surface contour of element No. SMP-1, containing pellets of solid solution ( $\mathrm{U}-20 \mathrm{w} / \mathrm{o} \mathrm{Pu}$ ) C, did not reveal ridges or irregularities that would correlate with pellet lengths. Gamma-scan indications interpreted to be separations between pellets could not be repeated when the element was reversed (end-for-end) in the vertical scanning device. Neutron radiography subsequently showed five or six loose pellets at the top of the column and one pellet fractured in the transverse direction.

c. Processes for Large-scale Preparation of $(\mathrm{U}, \mathrm{Pu}) \mathrm{C}$. A fluidized-bed process for the preparation of (U, Pu)C has been demonstrated in 15 runs in which high-purity (U,Pu)C was prepared on a scale of 300 to $600 \mathrm{~g}$ per batch by hydriding $\mathrm{U}-15 \mathrm{w} / \mathrm{O} \mathrm{Pu}$ alloy and then carbiding by reaction with methane-hydrogen fluidizing gas. ${ }^{9}$ Carbide fuel for irradiation testing is also being prepared by this technique. This process appears promising for large-scale production of carbides; calculations show that a single fluidized-bed reactor of 8 -in. dia could prepare $100 \mathrm{~kg} / \mathrm{day}$ of $(\mathrm{U}, \mathrm{Pu}) \mathrm{C}$ if operated at $10 \mathrm{~atm}$ pressure and $800^{\circ} \mathrm{C}$. However, some work remains to be done to perfect this process for large-scale synthesis of $(U, P u) C$.

To study problems of scaling up the fluidized-bed process, a semiworks-scale fluidized-bed reactor with an internal diameter of $2 \frac{1}{2}$ in. is being operated for preparation of UC on a scale of 1 to $2 \mathrm{~kg}$ per batch. The reactor was designed to be operated in an air environment [the fluidizedbed reactor for ( $\mathrm{U}, \mathrm{Pu}) \mathrm{C}$ preparation is operated in a helium-atmosphere glovebox]. It is also designed to discharge the product by conveying it

9. See Progress Report for December 1966, ANL-7286, p. 26, and Progress Report for February 1967 , ANL-7308, p. 31. 
pneumatically through a discharge tube to a product receiver that can be removed and opened in a helium-atmosphere glovebox. The reactor and its operation with once-through gas flow were described in the Progress Report for July 1966, ANL-7245, p. 8. With once-through gas flow the operating pressure was limited to about 2 atm because of the large flow of gas required at higher pressures. Adiaphragm compressor was therefore installed to recirculate the off-gas from the fluidized bed and allow operation at the reactor design pressure of $10 \mathrm{~atm}$.

Uranium in the form of acid-cleaned rods, 3/8-in. in diameter by $1 \mathrm{in.}$ long, is charged to the reactor through a lock which prevents the admission of air to the system. The uranium metal is reacted with hydrogen at about $250-300^{\circ} \mathrm{C}$ for 0.5 to $\mathrm{l} \mathrm{hr}$ to produce finely divided uranium hydride $\left(\mathrm{UH}_{3}\right)$, which decomposes to uranium metal as the temperature is raised. The metal particles are then reacted with hydrogen-methane gas at 4 to $10 \mathrm{~atm}$ pressure and 600 to $800^{\circ} \mathrm{C}$. The reaction of uranium metal with methane yields two moles of hydrogen for each mole of uranium reacted. The excess gas is released from the system through a back-pressure regulator; the rate of release is measured with a wet-test meter.

The methane concentration is automatically controlled by an infrared analyzer coupled with a recorder-controller. The amount of methane added to maintain the concentration is determined by the decrease in pressure in a small supply tank.

Analyses of the products of the four latest experiments (see Table XVIII) indicate that the carbide products have carbon contents close to the stoichiometric value and that low oxygen contents can be achieved. The fluidized-bed reactor is operated in an ambient air atmosphere rather

TABLE XVIII. Preparation of UC in a Fluidized Bed at 10 atm Pressure

$$
(1 \mathrm{~kg} / \mathrm{batch})
$$

\begin{tabular}{|c|c|c|c|c|c|c|}
\hline \multirow{2}{*}{$\begin{array}{c}\text { Expt } \\
\text { No. }\end{array}$} & \multirow{2}{*}{$\begin{array}{l}\text { Temp } \\
\left({ }^{\circ} \mathrm{C}\right)\end{array}$} & \multirow{2}{*}{$\begin{array}{c}\text { Gas } \\
\text { Velocity } \\
(\mathrm{cm} / \mathrm{sec})\end{array}$} & \multirow{2}{*}{$\begin{array}{c}\mathrm{CH}_{4} \\
\text { Concb } \\
(\mathrm{v} / \mathrm{o})\end{array}$} & \multirow{2}{*}{$\begin{array}{l}\text { Reaction } \\
\text { Time } \\
\text { (hr) }\end{array}$} & \multicolumn{2}{|c|}{$\begin{array}{c}\text { Product Analysis }{ }^{c} \\
(\mathrm{w} / \mathrm{o})\end{array}$} \\
\hline & & & & & Oxygen & Carbond \\
\hline 16 & 850 & 12 & 5 & 11 & 0.4 & 4.66 \\
\hline 17 & 810 & 18 & 5 & 11 & 0.094 & 4.85 \\
\hline 18 & 750 & $18^{\mathrm{e}}$ & 5 & 14.2 & 0.11 & 4.73 \\
\hline 19 & 775 & 12 & $2.5^{f}$ & 16.2 & 0.068 & $4.24^{\mathrm{g}}$ \\
\hline
\end{tabular}

a Temperature was measured at the top of the fluidized bed.

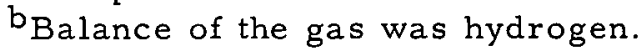

${ }^{c}$ Average of two analyses.

dStoichiometric UC contains $4.80 \mathrm{w} / 0$ carbon.

e Gas velocity lowered to $12 \mathrm{~cm} / \mathrm{sec}$ for two short periods during run (see Fig. 15).

$\mathrm{f}_{\mathrm{CH}_{4}}$ concentration raised to $5 \mathrm{v} / \mathrm{o}$ after $7 \frac{3}{4} \mathrm{hr}$.

Experiment was terminated before carbiding was complete. 
than in a helium-atmosphere. glovebox such as is used for the (U, Pu)C preparations cited above. The product is transferred by pneumatic con-

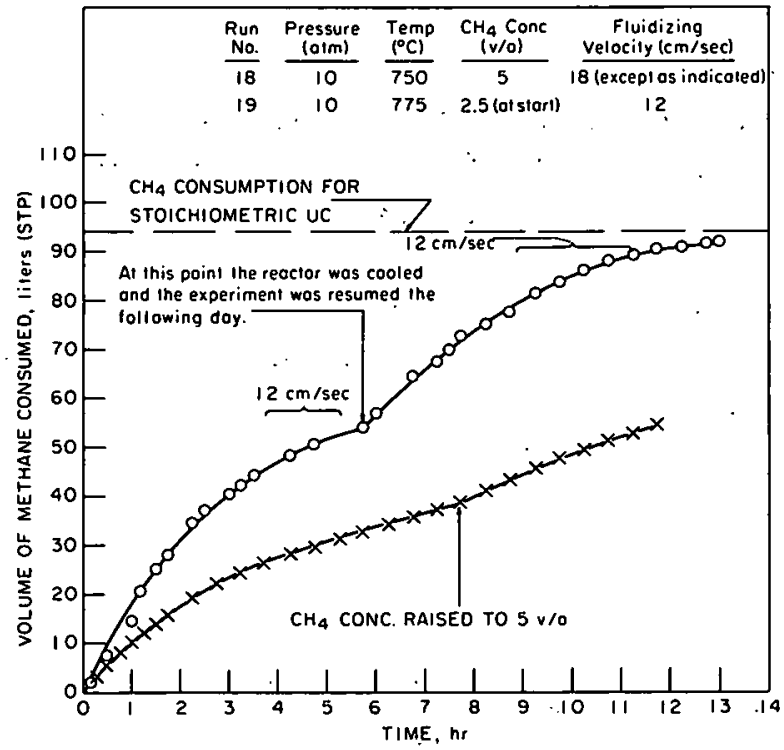

Fig. 15. Fluidized-bed Reaction of Uranium with Methane-Hydrogen Mixtures (1 kg/batch) veyance to a receiver that is subsequently removed and opened in a helium-atmosphere glovebox. The transfer of the product by pneumatic conveyance can usually be carried out by a single transfer, but occasionally repeated transfers are required to remove the product completely.

The rate of the reaction was determined by noting the rate of methane consumption. The data from two of these experiments are given in Fig. 15. The upper reaction curve shows that changes in the gas velocity do not affect the reaction rate. However, an increase in the methane concentration from 2.5 to $5 \mathrm{v} / 0$ does result in a slight increase in the rate of reaction, as shown by the lower

curve and by comparing both curves. It is also of interest to note the enhanced rate of reaction when the powder. is rehydrided oncooling the reactor overnight and reheating the next morning. This effect has been noted in the uranium-plutonium experiments and is attributed to the exposure of fresh surfaces as the uranium rehydrides.

One of the goals of the experimental program is to be able to predict the carbon content of the product from the methane utilization during the run. For these experiments, the amount of methane reacted was compared with the chemically determined carbon content of the powder at various stages of the reaction. For the recentexperiments, the resultscalculated from the methane consumption (correcting for methane in the gas released in maintaining the pressure) give a calculated carbon value for the final product which is within $0.1 \mathrm{w} / \mathrm{o}$ of the carbon content actually determined by chemical analyses.

After 19 experiments, it was necessary to replace the reactor heaters. At the same time, the reactor was opened and examined for any evidence of deterioration. The reactor vessel itself was used in approximately 10 experiments or for approximately $100 \mathrm{hr}$ at temperature. An $\mathrm{X}$-ray examination of the vessel gave no indication of any deterioration of the vessel wall.

The gas-inlet tube which extends from the top to the bottom of the reactor along the centerline was more extensively examined. The tube 
was sectioned and six samples were prepared for metallographic examination. Four of the samples were taken from the lower end of the tube, one from the midpoint of the gas phase, and one at the coldest portion of the tube. There was no evidence of attack in any of the samples except one, which was located near a weld and suffered grain separation to a depth of $1 \frac{1}{2}$ miles. This latter sample was examined with an electron microprobe. There was no indication of any alloying with uranium, nor was there any evidence for the accumulation of carbon on the outside wall of the gas entry line.

These results indicate that Type 304 stainless steel can be used as a material of construction for the fluidized-bed preparation of UC by the uranium-methane reaction. The reactors for preparing ( $U, P u) C$ are also constructed of Type 304 stainless steel and they too have shown no evidence of deterioration.

\section{Fuel Cladding and Structure}

a. Tube-burst Tests of Vanadium Alloys. Although tube-burst tests have been carried out on unirradiated stainless steel (see Progress Report for May 1966, ANL-7219, p. 13) and on stainless steel irradiated at temperatures in the range 371 to $520^{\circ} \mathrm{C}$ (see Progress Report for January 1967, ANL-7302, pp. 20-21), burst tests were made for the first time on tubes of $\mathrm{V}-15 \mathrm{w} / 0 \mathrm{Ti}-7.5 \mathrm{w} / \mathrm{O} \mathrm{Cr}$ in the present reporting period.

Eight inner capsule tubes of $\mathrm{V}-15 \mathrm{w} / \mathrm{o} \mathrm{Ti}-7.5 \mathrm{w} / \mathrm{o} \mathrm{Cr}$ from subassembly XO13 were on hand. These had initially been annealed for one hour at $1100^{\circ} \mathrm{C}$. The maximum fluence (at reactor midplane) was $6 \times 1.0^{21} \mathrm{n} / \mathrm{cm}^{2}$, and ir radiation temperature was about 600 to $650^{\circ} \mathrm{C}$ Each tube was cut into eight sections, about 4 in. long. A few tests have been made on the 4 -in. sections at 550,650 , and $750^{\circ} \mathrm{C}$. Unirradiated control specimens were also tested. The results are shown in Table XIX. Ductility has been indicated

TABLE XIX. Burst Strength and Ductility of $\mathrm{V}-15 \mathrm{w} / \mathrm{o} \mathrm{Ti}-7.5 \mathrm{w} / \mathrm{o} \mathrm{Cr}$ Tubing

\begin{tabular}{|c|c|c|c|c|c|c|}
\hline \multirow{2}{*}{$\begin{array}{l}\text { Test } \\
\text { Temp } \\
\left({ }^{\circ} \mathrm{C}\right)\end{array}$} & \multirow{2}{*}{$\begin{array}{l}\text { Specimen } \\
\text { Location }\end{array}$} & \multicolumn{2}{|c|}{$\begin{array}{l}\text { Max Tangential } \\
\text { Stress }\end{array}$} & \multicolumn{2}{|c|}{$\begin{array}{c}\text { Diameter change } \\
(\% \Delta \mathrm{D} / \mathrm{D}) \\
\end{array}$} & \multirow{2}{*}{$\begin{array}{l}\text { Time at Test } \\
\text { Temp (min) }\end{array}$} \\
\hline & & psi & $\mathrm{kg} / \mathrm{mm}^{2}$ & Range & Avg & \\
\hline \multirow[t]{5}{*}{550} & Unirradiated & 100,100 & 70.4 & b & b & 60 \\
\hline & Unirradiated & 101,300 & 71.3 & $\mathrm{~b}$ & $\mathrm{~b}$ & 60 \\
\hline & -10 to $-20 \mathrm{~cm}$ & 113,800 & 80.0 & $0.8-2.3$ & 1.4 & 130 \\
\hline & 0 to $-10 \mathrm{~cm}$ & 128,000 & 90.0 & $1.8-2.4$ & 2.0 & 90 \\
\hline & +50 to $+60 \mathrm{~cm}$ & 110,500 & 77.7 & $2.2-3.6$ & 2.8 & 30 \\
\hline \multirow[t]{4}{*}{650} & Unirradiated & 97,800 & 68.8 & $7.4-8.8$ & 8.1 & 45 \\
\hline & -10 to $-20 \mathrm{~cm}$ & 111,000 & 78.1 & $2.6-3.2$ & 2.9 & 35 \\
\hline & 0 to $-10 \mathrm{~cm}$ & 112,000 & 78.8 & $1.2-1.7$ & 1.4 & 120 \\
\hline & +50 to $+60 \mathrm{~cm}$ & 88,000 & 61.9 & $\mathrm{~b}$ & $\mathrm{~b}$ & 60 \\
\hline \multirow[t]{2}{*}{750} & Unirradiated & 90,200 & 63.4 & $6.9-8.6$ & 7.8 & 60 \\
\hline & +50 to $+60 \mathrm{~cm}$ & 89,300 & 62.8 & $2.2-6.8$ & 3.7 & 95 \\
\hline
\end{tabular}

aspecimen location above or below reactor midplane in $\mathrm{cm}$.

${ }^{b}$ Shattered or split so that no diameter measurements were possible. 
by the percent change in the diameter. of the tube. In some cases, the tube shattered to such an extent that no diameter measurements were possible. The time at test temperature is shown because of its possible relation to annealing effects, particularly at the higher temperatures. The variation in the time at temperature resulted from problems in getting a tight system.

At $550^{\circ} \mathrm{C}$ the maximum increase in burst strength is $27 \%$; at $650^{\circ} \mathrm{C}$ it is $13 \%$, and at $750^{\circ} \mathrm{C}$ (one specimen) there is no increase in strength due to the irradiation. At both 650 and $750^{\circ} \mathrm{C}$ the unirradiated specimens showed about twice the ductility of the irradiated. Presumably the shattered unirradiated specimens at $550^{\circ} \mathrm{C}$ test temperature had negligible ductility. One specimen at $650^{\circ} \mathrm{C}$ split open along its entire length.

Bohm et al. ${ }^{10}$ indicated that complete recovery of both strength and ductility of tensile specimens irradiated at $50^{\circ} \mathrm{C}$ occurred with vanadium alloys tested at 650 and $750^{\circ} \mathrm{C}$. The results of our biaxial tests are at variance with these data.

b. Development of Refractory-metal Alloys for Service in Oxygencontaminated Sodium. Small weight gains shown by V, V-5 w/o Cr, and $\mathrm{V}-15 \mathrm{w} / \mathrm{o} \mathrm{Ti}-7.5 \mathrm{w} / \mathrm{o} \mathrm{Cr}$ exposed for 88 days to flowing $(6.1 \mathrm{~m} / \mathrm{sec})$ sodium containing about $7 \mathrm{wt}$ ppm of oxygen were reported (see Progress Report for March 1967, ANL-7317, p. 58) to differ from one another less in tests at $550^{\circ} \mathrm{C}$ than at $650^{\circ} \mathrm{C}$. The same trend prevailed in April after 117 days of exposure, with the oxygen level now found by analysis to be $8 \mathrm{wt}$ ppm (cold trap at $\left.120^{\circ} \mathrm{C}\right)$.

The alloys have a faint brown tint, but otherwise appear metallic. The weight gains shown in Table XX are believed to fairly represent the relative pickup of impurities (mainly oxygen) from the flowing stream.

Table XX. Corrosion of Vanadium Alloys in Sodium at $550^{\circ} \mathrm{C}$ and Flowing with $6.1-\mathrm{m} / \mathrm{sec}$ Velocity

\begin{tabular}{llllll}
\hline & \multicolumn{5}{c}{ Weight Gain, $\mathrm{mg} / \mathrm{cm}^{2}$ at Indicated Time (days) } \\
\cline { 2 - 6 } Alloy & 6.9 & 20.9 & 53.8 & 88.7 & 116.5 \\
\hline $\mathrm{V}$ & 0 & 0.06 & 0.08 & 0.16 & 0.16 \\
$\mathrm{~V}-5 \mathrm{Cr}$ & 0 & 0.032 & 0.064 & 0.075 & 0.075 \\
& 0 & 0.043 & 0.065 & 0.086 & 0.086 \\
$\mathrm{~V}-20 \mathrm{Ti}$ & 0.089 & 0.20 & 0.25 & 0.29 & 0.31 \\
& 0.079 & 0.21 & 0.26 & 0.30 & 0.33 \\
$\mathrm{~V}-15 \mathrm{Ti}-$ & 0.077 & 0.15 & 0.22 & 0.30 & 0.32 \\
$7.5 \mathrm{Cr}$ & 0.088 & 0.17 & 0.22 & 0.30 & 0.32 \\
Oxygen &. & & & &. \\
level (Hg & & 7.8 & 9.7 & 6.5 & 8.5 \\
amalg) & - & &
\end{tabular}

${ }^{10}$ Bohm, H., et al., Irradiation Effects on the Mechanical Properties of Vanadium-base Alloys, presented at the Sixty-Ninth Annual Meeting of ASTM, Atlantic City, New Jersey, June 27-July 1, 1966, Paper No. 75. 
A newer high-strength alloy (V-15 w/o Cr-5 w/o Ti) became available at the last inspection, and specimens are now included in the continuing test. It is presently planned to terminate the $550^{\circ} \mathrm{C}$ dynamic testing after an additional two exposures of one month each.

Static (oxygen refreshed) testing at $450^{\circ} \mathrm{C}$ has started. Samples of various vanadium alloys exposed in low-oxygen sodium (CT $110^{\circ} \mathrm{C}$, $1.5 \mathrm{ppm} O$ by distillation) lost a very small amount of weight (less than $0.02 \mathrm{mg} / \mathrm{cm}^{2}$ ) in 7 days.

In sodium of higher oxygen concentration $\left(\mathrm{CT} 175^{\circ} \mathrm{C}, 13 \mathrm{ppm} \mathrm{O}\right.$ by distillation) V-20 w/o Ti samples gained about $0.08 \mathrm{mg} / \mathrm{cm}^{2}$, while V-15 w/o $\mathrm{Cr}-5 \mathrm{w} / \mathrm{o} \mathrm{Ti}$ lost about $0.6 \mathrm{mg} / \mathrm{cm}^{2}$ after 6.8 -day exposure at $450^{\circ} \mathrm{C}$.

c. Effect of Mechanical Properties on Nickel-base Alloys in $650^{\circ} \mathrm{C}$ Sodium. Nimonic $80 \mathrm{~A}$ specimens were selected as control material for conducting mechanical property tests in $650^{\circ} \mathrm{C}$ sodium for $\mathrm{Ni}-\mathrm{Cr}-\mathrm{Fe}$ alloys (see Progress Report for February 1967, ANL-7308, pp. 34-35). These control specimens were machined from doubly annealed stock $\left(1080^{\circ} \mathrm{C} / 8 \mathrm{hr} /\right.$ air cooled and $200^{\circ} \mathrm{C} / 16 \mathrm{hr} /$ air cooled) and then creep tested at $650^{\circ} \mathrm{C}$ in commercial tensile machines (Instron), adapted, with special furnaces for testing in low-oxygen sodium and in vacuum at $10^{-6}$ Torr. In the case of sodium, the oxygen content was maintained below 5 ppm by hot gettering with zirconium chips. Oxygen measurements were made using internal-friction techniques. A stress of $46.2 \mathrm{~kg} / \mathrm{mm}^{2}$ was applied to the specimen after the furnace had been at $650^{\circ} \mathrm{C}$ temperature for $24 \mathrm{hr}$.

The results of these tests were that specimens of Nimonic $80 \mathrm{~A}$ exposed in $650^{\circ} \mathrm{C}$ sodium prematurely rupture in $212 \mathrm{hr}$ with a true strain of $1.2 \%$, whereas a corresponding specimen in vacuum at $650^{\circ} \mathrm{C}$ ruptured in $765 \mathrm{hr}$ with a true strain of $4.60 \%$. There was also a $25 \%$ reduction in strain rate in the third stage of creep in sodium as compared to that in vacuum, while there was no change in corresponding rates during the first and second stages of creep. These results indicate the surface energy of Nimonic 80A is lowered by liquid sodium penetrating into the grain boundaries of the alloy. Since this test was conducted with no mass flow in an isothermal chamber of Type 304 stainless steel, it can only be used as a screening test for studying the effect of sodium exposure on mechanical properties of $\mathrm{Ni}-\mathrm{Cr}-\mathrm{Fe}$ alloys under the specific test conditions. A program (and the necessary equipment) for a more meaningful study has been proposed.

d. Effect of High-temperature Sodium on Type 304 Stainless Steel. Deleterious effects of $650^{\circ} \mathrm{C}$ sodium on stainless steel, as evidenced by accelerated attack of Strauss reagent or aluminum sulfate solution on sodium exposed samples has been reported (e.g., Progress Report for January 1967 , ANL-7302, pp. 42-45). In cooperation with the Reactor Engineering Division, the Applied Corrosion Group of the Metallurgy Division is trying to determine the cause of these effects. 
Preliminary experiments have been carried out in low-oxygen ( $8 \mathrm{ppm}$ by mercury amalgamation technique) sodium and in vacuum at $650^{\circ} \mathrm{C}$. After eight days at $650^{\circ} \mathrm{C}$ there was essentially no difference in response to Strauss reagent of samples exposed in the relatively pure sodium and in vacuum. It is thus tentatively concluded that the effect of sodium on stainless steel is dependent on impurities in the sodium.

\section{Fuel Reprocessing}

a. Processes for Fast Reactor Fuels. Pyrochemical processing of fast reactor fuels of the ceramic type (e.g., oxide or carbide) clad with stainless steel is being investigated. A conceptual flowsheet currently under investigation has been described previously (see Progress Report for September 1966, ANL-7255, pp. 30-31). The process utilizes liquid metalmolten salt extractions and salt-transport separations for the separation of fissile and fertile constituents of the fuel from the fission products. Recent laboratory investigations of the current flowsheet are discussed below.

The first step after the decladding of mixed oxide $\left(\mathrm{PuO}_{2}-\mathrm{UO}_{2}\right)$ fuels is the reduction of the oxide to metal (plutonium and uranium) by a liquid $\mathrm{Cu}-33 \mathrm{w} / \mathrm{O} \mathrm{Mg}$ alloy in contact with a molten salt (see ANL-7255, pp. 30-31). The alkali, alkaline earth, and rare earth fission products and the solid $\mathrm{MgO}$ formed as a byproduct of the reduction reaction remain in the waste salt. The plutonium, uranium, and noble and refractory metal fission products are transferred into the $\mathrm{Cu}-\mathrm{Mg}$ alloy; the plutonium is in solution and the uranium is present as a precipitated metal phase.

Laboratory-scale investigations of the variables which influence the reduction of $\mathrm{UO}_{2}$ in molten salt-liquid metal systems have continued.

Several experiments were performed to study the effect of agitation speed on the reduction rate of $\mathrm{UO}_{2}$ in a $42.5 \mathrm{~m} / \mathrm{o} \mathrm{NaCl}-37.5 \mathrm{~m} / \mathrm{o}$ $\mathrm{CaCl}_{2}-15 \mathrm{~m} / \mathrm{OMgCl}_{2}-5 \mathrm{~m} / \mathrm{o} \mathrm{CaF}_{2} / \mathrm{Cu}-33 \mathrm{w} / \circ \mathrm{Mg}$ system at $800^{\circ} \mathrm{C}$. Tests were made at agitation speeds of 600,800 , and $1000 \mathrm{rpm}$, and oxide loadings of 2 and $5 \mathrm{w} / \mathrm{o}$. The results show that variations in the agitation speed (between 600 and $1000 \mathrm{rpm}$ ) have no effect on the reduction rate in this system. The reductions achieved with this salt mixture have been only $\sim 90 \%$ complete in $4 \mathrm{hr}$, which indicates that this mixture is not satisfactory as a reduction salt. However, reductions of $>99 \%$ are currently being achieved in $2 \mathrm{hr}$ with a salt containing $47.5 \mathrm{~m} / \mathrm{o} \mathrm{MgCl}_{2}-47.5 \mathrm{~m} / \mathrm{o} \mathrm{CaCl}_{2}-5 \mathrm{~m} / \mathrm{o} \mathrm{CaF}$.

An increasing level of iron contamination in EBR-II fuel has been reported (see Progress Report for November 1966, ANL-7279, p. 9). The skull-reclamation process developed for EBR-II, but not installed in the Fuel Cycle Facility, has a demonstrated capability of separating. $>99 \%$ iron from uranium. ${ }^{11}$ The use of molten cerium as an extractant to remove

\footnotetext{
1.1.ANL-6569, p. 36; ANL-6413, p. 52 .
} 
iron from liquid uranium-fissium fuel has been proposed. An experiment was conducted to determine the distribution coefficient of iron between the relatively immiscible liquid cerium and uranium-fissium phases. The data from the experiment show the distribution coefficient (ratio of w/o Fe in cerium to $\mathrm{w} / \mathrm{O} \mathrm{Fe}$ in uranium-fissium) to be about 0.2 at temperatures between 1000 and $1200^{\circ} \mathrm{C}$. This value indicates that ir on could be extracted from uranium-fissium, using cerium, with repetitive extractions. However, because uranium is slightly miscible with cerium, some uranium would have to be subsequently recovered from the cerium.

Another experiment was conducted to determine if iron could be separated from uranium by the selective precipitation of uranium as a zincuranium intermetallic compound from a liquid $\mathrm{Zn}-\mathrm{Fe}-\mathrm{U}$ alloy. An alloy was made which contained about $2 \mathrm{w} / \mathrm{o}$ iron in uranium (on a zinc-free basis). After dissolving the alloy in zinc at $800^{\circ} \mathrm{C}$, filtered metal samples were taken during a controlled cooling period. A one-hour mixing period and a $30-\min$ settling period preceded sampling at each temperature. The results expressed in terms of the Doerner-Hoskins coprecipitation coefficient $\lambda^{12}$ were $\sim 0.03$ from 800 to $580^{\circ} \mathrm{C}$ and $\sim 0.43$ from 580 to $425^{\circ} \mathrm{C}$. The differences in the coprecipitation coefficients over the temperature range indicate a difference in the form of the material being precipitated. These results show that iron could be separated from uranium by a selective precipitation process, but implementation of this method of iron removal from EBR-II fuel in the Fuel Cycle Facility would require a new furnace and some modification of existing equipment, as well as new retorting facilities for recovery of the uranium product.

Engineering studies for the plutonium salt transport process have shown that reductions of 98 to $100 \%$ are obtained when $47.5 \mathrm{~m} / \mathrm{o}$ $\mathrm{MgCl}_{2}-47.5 \mathrm{~m} / \mathrm{oCaCl}_{2}-5 \mathrm{~m} / \mathrm{oCaF}_{2}$ is used as the salt phase with a $\mathrm{Cu}-33 \mathrm{w} / \mathrm{o}$ $\mathrm{Mg}$ alloy. However, in the subsequent extractions steps it is desirable to use a salt of lower $\mathrm{MgCl}_{2}$ content in order to minimize plutonium losses. An experiment has been completed in which the $\mathrm{MgCl}_{2}$ content of the salt was decreased by adding calcium and lithium metal to the salt-metal system at about $700^{\circ} \mathrm{C}$. Magnesium oxide was added to the salt to simulate the reduction product, and cerium was added to determine its distribution coefficient in the resultant salt-metal system. Complete analytical results are not available, but preliminary analyses show that the chemistry of the process proceeded as expected with a resulting salt composition of about $56 \mathrm{~m} / \mathrm{OCaCl}_{2}-15 \mathrm{~m} / \mathrm{o} \mathrm{MgCl}_{2}-24.6 \mathrm{~m} / \mathrm{o} \mathrm{LiCl}-4.4 \mathrm{~m} / \mathrm{o} \mathrm{CaF} 2$. This composition should be suitable for the extraction steps.

Engineering studies to test various equipment components in a flowing molten chloride salt stream have been completed. The system,

${ }^{12}$ The Doerner-Hoskins coefficient $\lambda$ is defined by $\log \left(\frac{\text { traceí in solution }}{\text { total tracer }}\right)=\lambda \log \left(\frac{\text { carrier in solution }}{\text { total carrier }}\right)$. 
which was described previously (see Progress Report for December 1966, ANL-7286, p. 33), has been operated a total of $1348 \mathrm{hr}$ circulating $50 \mathrm{~m} / \mathrm{o}$ $\mathrm{MgCl}_{2}-30 \mathrm{~m} / \mathrm{o} \mathrm{NaCl}-20 \mathrm{~m} / \mathrm{o} \mathrm{KCl}$ at an average temperature of $560^{\circ} \mathrm{C}$ and an average flow rate of $1 \mathrm{gpm}$. During the last $328 \mathrm{hr}$ of operation the salt also contained $\mathrm{UCl}_{3}$ and $\mathrm{ZnCl}_{2}$.

Metallographic examination of the system revealed no significant change in wall thickness, but intergranular penetration of up to $0.05 \mathrm{~mm}$ was observed. In stressed sections the penetration was somewhat greater. A freeze valve in the drain line of the system had been opened and closed approximately 40 times. As a result of these operations the valve was badly distorted and cracked. Although the life of this type of valve is limited, freeze valves are still useful in locations where frequent operation is not required. The centrifugal pump performed well, although an oil seal leaked some oil into the salt. The pump employed a hydrostatic bearing which supported the impeller shaft in the circulating fluid. This feature will be especially useful in pyrochemical-processing equipment because these processes use relatively deep vessels.

A niobium crucible is being tested in a materials evaluation program to find suitable materials for pyrochemical processing equipment. The crucible $\left(4 \frac{3}{4}-i n\right.$. in $O D$ by $6 \frac{1}{2}$-in. high with a 0.060 -in. wall) was fabricated by rolling and welding niobium sheet. Four mixing baffles extend $3 / 4 \mathrm{in}$. into the crucible. This crucible has been tested for $528 \mathrm{hr}$ with a $\mathrm{Cu}-33 \mathrm{w} / \mathrm{OMg}-0.1 \mathrm{w} / \mathrm{oU} / \mathrm{MgCl}_{2}-30 \mathrm{~m} / 0 . \mathrm{NaCl}-20 \mathrm{~m} / \mathrm{o} \mathrm{KCl}$ system at $700^{\circ} \mathrm{C}$. After $384 \mathrm{hr}$ the crucible was cleaned with nitric acid and inspected. No evidence of corrosion was detected. The crucible does, however, appear to be slowly losing its ductility, probably as a result of temperature cycling and salt embrittlement. After $528 \mathrm{hr}$ the crucible was subjected to severe physical shock to determine if sufficient embrittlement had occurred to cause fracture. A dent was produced, but the crucible did not fracture. This study will be continued using $50-\mathrm{hr}$ exposures until the crucible fails or a total exposure of $1000 \mathrm{hr}$ has been obtained.

Engineering studies are under way to investigate the use of a zinc dissolution process as a simplified head-end step for decladding of oxide fuel assemblies from fast reactors. Remote disassembly and mechanical decladding involves a number of complex cutting and handling operations which require equipment that is both costly and difficult to maintain. The process being investigated involves the dissolution of stainless steel cladding and fuel-element structure in molten zinc at $800^{\circ} \mathrm{C}$ to form a 5 to $7 \mathrm{w} / \mathrm{o}$ solution of stainless steel in zinc. The bulk of the solution would then be transferred away, leaving the oxide fuel and residual zinc-stainless steel solution in the decladding crucible.

An experiment was performed in a retorting furnace to determine if the solvent zinc could be recovered from the zinc-stainless steel solution 
discharged from the decladder. The results of the experiment show that $98 \%$ of the zinc can be recovered by retorting at $850^{\circ} \mathrm{C}$ at a pressure of 10 Torr. The remaining zinc was combined with the stainless steel as a hard, adherent sintered mass. Evaluation of the costs involved in a plantscale operation will be made to determine whether such zinc recovery represents an economical advantage over discarding the solvent zinc, as radioactive waste.

F. Design Concept Analyses and Advanced Systems Evaluation

1. 1000-MWe Study

a. General. Procedures for project control and reporting 1000-MWe LMFBR follow-on studies have been written; they are being reviewed by $A E C$.

b. Combustion Engineering, Inc. The contract with Combustion Engineering, Inc. was executed; it provides that the work be done on a costplus-fixed-fee basis between February 6, 1967 and August 6, 1968.

The objectives of the study are: (a) to prepare a reference design of specific areas of the heat-generation system of a $1000-\mathrm{MWe}$ LMFBR nuclear steam-supply system, observing specified ground rules and based on an estimation of the state of technology attainable in 1980 , and (b) to identify the research and development programs required and to establish their relative merit by means of a cost-benefit study.

Program reporting and planning will be by means of the Program Evaluation and Review Technique (PERT) system.

c. Babcock \& Wilcox. B\&W has essentially completed the four conceptual designs in the Task I effort. (see Progress Report for March 1967, ANL-7317, pp.62-63). From an evaluation of the best features of each concept, the company is selecting the major features of a reference design. In-depth engineering of the reference design in Task II will begin as a parallel effort with trade-off studies so as to provide information necessary to choose the final reference design.

Babcock \& Wilcox submitted its first formal progress report for the period October 15, 1966 to March 1, 1967.

\section{G. General Research and Development}

1. Fast Reactor Core-parameter Study

Sodium-void coefficients have been calculated using the perturbation technique and the DEL subroutine of the MACH-I code. The power density 
studied was $400 \mathrm{~kW} /$ liter. Results were obtained running both radial and axial problems with the code. A feature of the DEL subroutine is the possibility of varying the limits of integration in the transverse direction, that is, perturbing the sodium content only in that portion of the central region corresponding to the physical core. This was the method adopted. The results show that the perturbation method is in at least approximate agreement with the Meneghetti method reported previously (see Progress Report for February 1967, ANL-7308, p. 41). For example, at a core height-to-diameter (H/D) ratio of 0.6 , for which the Meneghetti method gave a sodium-void coefficient of 1.00851 , the radial perturbation gives 1.00767 and the axial perturbation gives 1.00781 . For a low value of $H / D$, such as 0.2 , the axial perturbation gives results closer to the Meneghetti technique than the radial perturbation. This might be expected, because for a pancake core the axial (slab) representation is more reasonable than the radial (cylinder) representation.

- Preliminary results have been obtained for a two-dimensional problem that has been set up and run on the CANDID-2D code. The reactor studied has critical compositions derived using one-dimensional selfconsistent diffusion theory on the $M A C H-I$ code. It has $H / D=0.6$ and core power density $=400 \mathrm{~kW} /$ liter. The two-dimensional representation consisted of core, axial blanket, radial blanket, and reflector. A space mesh of $12 \times 12$ was used first, with convergence criteria of $1.0 \times 10^{-3}$. Under these conditions the value of $k$ converged to 1.0027 . The mesh then was doubled to $24 \times 24$ and the convergence criterion tightened to $1.0 \times 10^{-4}$. Under these conditions the value of $\mathrm{k}$ converged to 1.0009 . An effort to further double the mesh to $48 \times 48$ has caused machine trouble, apparently due to inadequate capability to handle such a large problem. 


\section{GENERAL REACTOR TECHNOLOGY}

\section{A. Applied and Reactor Physics Development}

1. An Improved Diagnostic Technique for Input-Output Equipment

There are certain difficulties involved in the diagnosis of malfunctions in electromechanical input-output equipment for computers. For one thing, it is not always easy to determine whether the trouble is in the device itself or in the interface. Furthermore, the mechanical parts in these devices move so rapidly that direct visual observation of their action is often impossible. Also, it is often difficult to display the electrical signals involved in a meaningful way.

In the process of maintaining a DDP- 24 computer system, an improved diagnostic technique has been developed which is intended to assist in eliminating these difficulties and in yielding more accurate and enlightened diagnoses. This computer, like others in its class, has a number of output control pulse (OCP) lines. A pulse may be made to appear on any of these lines by executing an OCP instruction with the appropriate address. The technique, then, involves the use of specially written diagnostic programs that are arranged to execute an $O C P$ instruction addressed to an external line before each operation of the device under test. The OCP line so addressed is connected to the delaying sweep external-trigger input of an oscilloscope. The waveforms of various signals in the interface may be thus displayed in synchronism with the operation of the device. In this way, one may check the operation of the interface and examine the signals generated by the device. Such tests can very rapidly confirm or rule out the possibility of trouble in the interface.

In addition, the delayed trigger from the oscilloscope can be made to trigger a stroboscope illuminating the moving mechanical parts of the device. The resulting flash from the stroboscope will reveal the status of the moving part at that point in the operating cycle.

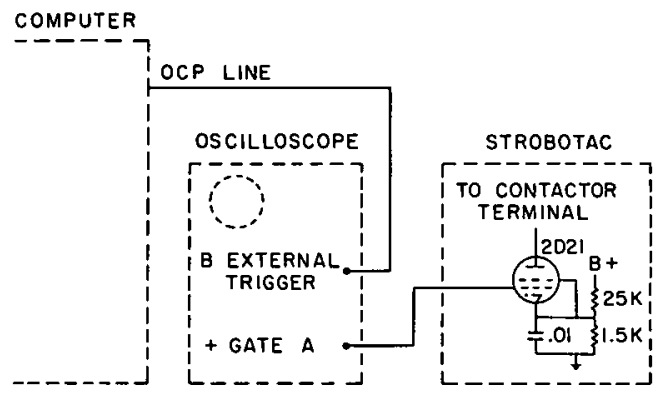

Fig. 16. Block Diagram for Diagnostic Equipment Arrangement
A block diagram of the layout is shown in Fig. 16.

The OCP line is connected to the external trigger input of time base $B$ on a Tektronix 545A oscilloscope. With the oscilloscope probes connected to the circuits under test, the waveforms at those points will be displayed on that time base in synchronism with the operation of the device. 
Time base A may be used in the normal delayed-sweep mode to display small portions of the cycle. For example, it is convenient for observing the behavior of contacts at the time of opening or closing.

The stroboscopic function is performed by a General Radio Strobotac, type 631-BL. As shown in Fig. 16, a 2D21 thyratron was connected across the CONTACTOR terminals of the Strobotac, which is operated in the CONTACTOR LOW mode. This thyratron is fired by the initiation of the CGATE A signal from the oscilloscope. With the oscilloscope operated in the B INTENSIFIED BY A mode, the left-hand edge of the intensified region indicates the instant of Strobotac firing. Thus the mechanical and electrical indications may be correlated.

A number of special diagnostic codes have been written for use with this technique. They are used for diagnosing a Selectric typewriter, a paper-tape punch, and a line printer.

The technique has also been applied to the diagnosis of centralprocessor malfunctions. Sometimes a machine instruction will malfunction, often only with a particular data configuration in the machine registers. A diagnostic program is then written to establish the configuration in question, pulse an OCP line, execute the instruction, and repeat. The various circuits involved can then be readily checked. Since there are so many possible situations, these programs are written as needed.

If an on-line system has its OCP lines permanently connected to various external devices, it would be convenient to reserve one line for maintenance. Various diagnostic programs could then use this line for synchronizing with different functions.

\section{The ARC System}

A significant improvement has been made in the $M C^{2}$ code in that the total inelastic and $n, 2 n$ cross sections are now evaluated at the ultrafinegroup level. In the previous version of the code, these cross sections were evaluated at the fine-group level.

The inelastic and $n, 2 n$ transfer matrices are still obtained at the fine-group level, but these matrices are now normalized to the ultrafinegroup total inelastic and $n, 2 n$ absorptions for the corresponding fine group.

For example, let the ultrafine group ( $u f g$ ) $j$ be contained in the fine group ( $\mathrm{fg}$ ) $\mathrm{J}$. Then in the calculation of the fundamental-mode spectrum, the source into ultrafine group $j$ due to inelastic scattering, $S_{i n e}$ ufg $_{j}$, is now
evaluated as 


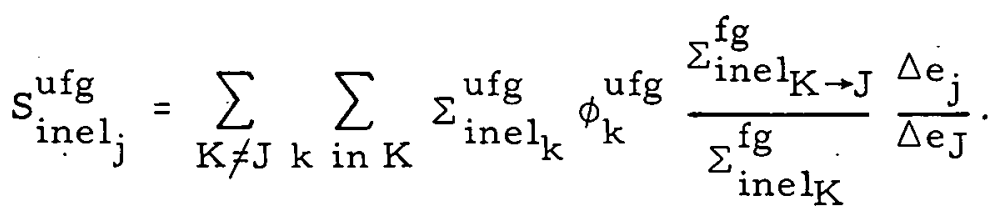

In Eq. (1), $\sum_{\text {inel }_{k}}^{\text {ufg }}$ is the total macroscopic inelastic cross section for ufg $k, \phi_{k}^{u f g}$ is the flux for ufg k, $\sum_{i n e l_{K \rightarrow J}}^{f g}$ is the macroscopic inelastic scattering cross section from $\mathrm{fg} \mathrm{K}$ to $\mathrm{fg} \mathrm{J}$, and $\Sigma_{\text {inel }}^{\mathrm{fg}}$ is the total macroscopic inelastic cross section for $f g K$. The $\Delta e_{j}$ and $\Delta e_{J}$ are, respectively, the energy widths of the ufg $\mathrm{j}$ and the $\mathrm{fg} \mathrm{J}$.

The corresponding loss term in the denominator of the fundamentalmode flux equation is therefore given by

$$
\sum_{\text {inel }_{j}}^{u f g}\left[1-\frac{\sum_{\text {inel }}^{f g} \rightarrow J}{\sum_{\text {inel }}^{f g}}\right] \text {, }
$$

where the term in the bracket accounts for the fact that self-scatter is not included in the equation.

To illustrate the improvement in the results using the new ultrafinegroup technique, $\mathrm{MC}^{2}$ problems have been run for a composition typical of a large oxide-fueled fast reactor. Three problems were run with fg lethargy widths $\Delta U$ of $0.5,0.25$, and 0.166666 for both the original fg treatment and the improved ufg treatment. Improved spectra resulted.

Improvement obtained by use of the code is shown in Table XXI, where the broad-group elastic removal cross sections for $\mathrm{Fe}, \mathrm{Na}$, and $\mathrm{O}$ are compared for the $\mathrm{fg}$ and ufg inelastic treatment.

TABLE XXI. Elastic Removal Cross Sections for the Light Elements

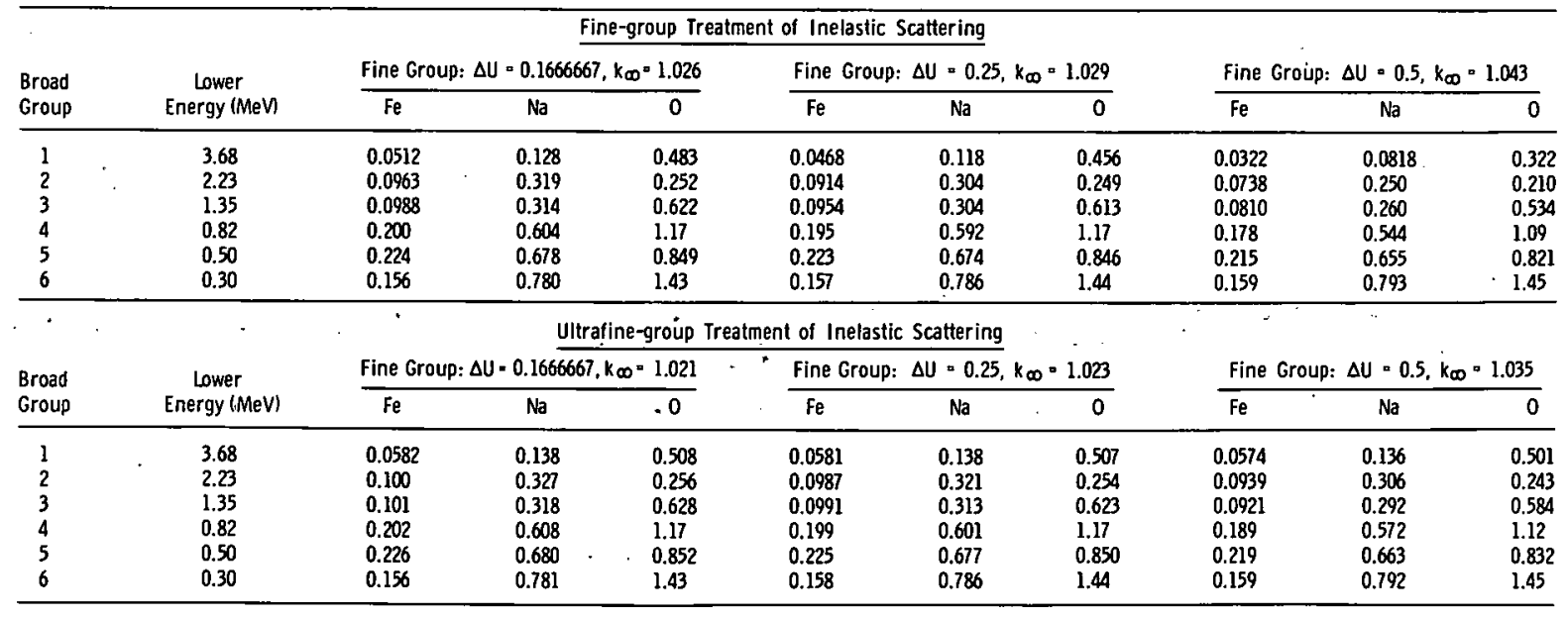


The use of the fine-group treatment of inelastic scattering is too crude for making accurate reactivity calculations. From Table XXI, one can see that this can lead to a criticality error of about $2 \%$ for this particular composition.

3. Cross-section Evaluations

The ET $\phi E$ code, prepared by the Atomic Power Development Associates, was adapted by them for use on the CDC-3600 computer. This code reads data from an ENDF/B library tape and produces a library tape in the format required by the $\mathrm{MC}^{2}$ code. A test $\mathrm{MC}^{2}$ library tape containing data for $\mathrm{Fe}, \mathrm{Na}, \mathrm{U}^{238}, \mathrm{Pu}^{239}$ and $\mathrm{Pu}^{240}$ materials was made using data from the first ENDF/B distribution. This test tape and the current version of the $\mathrm{MC}^{2}$ library tape were used to solve a reactor problem involving the above-mentioned materials. The critical bucklings found using these two tapes differed by an amount corresponding to about $1 \frac{1}{2} \%$ in reactivity, with cross sections in the current version of the $\mathrm{MC}^{2}$ library tape being more reactive than those based on $\mathrm{ENDF} / \mathrm{B}$ library tape.

\section{B. Reactor Fuels and Materials Development}

1. Chemistry and Fuels Materials

a. Behavior of Uranium Monophosphide. "Tests have shown that uranium monophosphide (UP) and tungsten interact negligibly in times up to $5 \mathrm{hr}$ and at temperatures up to $2593 \pm 10^{\circ} \mathrm{C}$ if the UP is maintained stoichiometric. If preferential vapor loss of phosphorus from the UP occurs at high temperatures, a limited amount of a ternary U-P-W liquid forms at the interface of the UP and tungsten grains. No solid solubility of UP in tungsten or of tungsten in UP was detected metallographically.

Thermal analysis of a UP-W charge in a tungsten crucible was followed with a Leeds and Northrup recording optical pyrometer. A thermal arrest was observed at $2630 \pm 20^{\circ} \mathrm{C}$ on cooling. Metallographic examination of the products of this test, of the (partial) reaction of UP in contact with tungsten at $2647 \pm 10^{\circ} \mathrm{C}$, and of the compatibility test at $2593^{\circ} \mathrm{C}$ suggest that (1) UP and tungsten form a simple eutectic system, (2) the observed thermal arrest temperature is the eutectic temperature, and (3) the composition of the eutectic is $\sim 20-30 \mathrm{w} / 0$ tungsten. The previously reported melting point $\left(2610 \pm 20^{\circ} \mathrm{C}\right)$ of UP, observed from its slumping in a tungsten crucible, is probably the eutectic temperature; the true melting point may be significantly higher.

b. Preparation of Fuel Specimens in Helium. Procedures for the preparation of ceramic fuels for metallographic examination are being tested in a glovebox containing a helium atmosphere. The purpose of the test is to develop fuel-handling techniques which can subsequently be applied in a helium atmosphere enclosure of a shielded fuel evaluation facility which is now under construction in the Chemistry Division cave complex. 
In the tests, the helium used in the glovebox was continuously purified.(by a cryogenic method) to minimize the reaction of impurities with simulated ceramic fuels. Typically, the combined moisture and oxygen impurities were <10 ppm, with the oxygen fraction seldom exceeding 2 ppm.

Materials selected for initial testing were pressed-and-sintered UC and arc-melted $U C_{x}$. Sections of the fuel selected for testing were mounted in cylindrical plastic molds with epoxy resin. Grinding of the specimens was carried out on wheels surfaced with SiC papers with 80, 120, $180,320,400$, and $600 \mathrm{grit}$ sizes, and polishing was carried out on Buehler "Texmet" cloths impregnated with 6- and 1 -micron diamond paste. A Buehler "Whirlimet" apparatus was employed in the grinding and polishing steps, and a mixture of hydrogenated terphenyls (a Monsanto product, HB-40) was used as lubricant for the specimens. The specimens were cleaned ultrasonically with "Freon" TF solvent (a du Pont product, $C C l_{2} F-C C l F_{2}$ ) and/or reagent-grade benzene. The benzene-cleaned specimens were vacuum dried. Optical inspection of the prepared specimens was accomplished by remote viewing through a metallurgical microscope which was installed in the glovebox.

Cleaning of the surfaces of pressed-and-sintered UC specimens with benzene produced discolorations of various shades of brown; however, these discolorations did not reveal the structure of the material. On the other hand, benzene cleaning of the arc-melted specimens-revealed the presence of large irregular grains approximately $1 \mathrm{~mm}$ in cross section. The grains were sharply defined by color variations, predominantly white, green, blue, red, and yellow. Examination of an a rc-melted specimen with an electron-probe microanalyzer indicated that the various colored grains were of similar composition. Apparently, impurities in the benzene (major impurity, $550 \mathrm{ppm} \mathrm{H}_{2} \mathrm{O}$ ) had reacted with the surface of arc-melted carbide to form an interference film which produced colors that varied with orientation of the grains. Accary ${ }^{13}$ had previously noted similar grain-coloring effects when carbide specimens (arc-melted or. sintered) were etched in acid solutions.

Simulated uranium carbide fuel specimens prepared by the above procedures were not stained when cleaning after the final diamond polish was accomplished with the use of "Freon" $\mathrm{TF}\left(\mathrm{CCl}_{2} \mathrm{~F}-\mathrm{CClF}{ }_{2}\right)$. Some microstructure was revealed in arc-melted $U_{\mathrm{X}}$ but was not apparent in pressedand-sintered UC. The polished surfaces showed no apparent change after storage under helium for three weeks.

To determine if air etching would reveal the microstructure of the UC specimens, they were exposed to room atmosphere. Fracturing of the polished surfaces by reaction with air, which occurred within $16 \mathrm{hr}$, did little to assist in revealing fuel structure.

13 Accary, A., J. Nucl. Mater. $\underline{8}(3), 281$ (1963). 
Cathodic etching of ceramic fuel specimens will be tested as a possible method of defining microstructure. An advantage of this etching. technique is that the fuel surfaces will not be contaminated with conventional acid etchants which may interfere with subsequent microprobe or mass analysis.

c. Sampling of Irradiated $\mathrm{UO}_{2}$ by Microdrilling. Data on the fission product and heavy element isotopic composition changes within irradiated fuel can readily be obtained from fuel samples obtained by drilling. A commercial microdrill (Dumore Co., Racine, Wis.) has been adapted for remote use, and preliminary tests of the unit for sampling irradiated fuel have been completed. The fuel used in the sampling tests was a $\mathrm{UO}_{2}$ fuel pellet, $3.8 \%$ enriched in $U^{235}$, irradiated to about $1.2 \mathrm{a} / \mathrm{o}$ burnup in the General Electric Test Reactor, and cooled for more than one year prior to sampling. To prepare the fuel for sampling, a radial section of the pellet was ground and polished. A macrophoto of the polished specimen showed radial cracking of the $\mathrm{UO}_{2}$ but no evidence of fuel melting.

Twelve samples, $0.020 \mathrm{in.}$ in diameter and $0.015 \mathrm{in}$. in depth, were drilled across the 0.494-in: diameter of the fuel so that the centers of the sampling areas were $0.040 \mathrm{in}$. apart. Analytical samples were taken during drilling by vacuuming the powder through a hypodermic needle (ID of 0.032 in.) and collecting it on filter paper with an average pore size of $0.8 \mu$. The solid fuel samples were first analyzed gamma spectrometrically, and then dissolved for analysis of uranium and plutonium.

Appreciable density change across the fuel diameter was indicated by the variation in the amount of uranium in the samples. The analyzed weight of uranium in the 12 drillings of equal depth and diameter varied by a factor of four (from 105 to $400 \mu \mathrm{g}$ ). Therefore, in determining the distribution of fission elements in the fuel it was assumed that the amount of fuel in each sample was proportional to the amount of uranium present. Fission element activity per milligram of uranium in the individual samples was normalized to that of the sample containing the lowest level of activity of the element per milligram of uranium.

Gamma photopeaks that could be resolved in each drilled sample were those of $\mathrm{Zr}^{95}-\mathrm{Nb}, \mathrm{Cs}^{137}, \mathrm{Ce}^{144}-\mathrm{Pr}$, and $\mathrm{Ru}^{106}-\mathrm{Rh}$. The redistribution of $\mathrm{Zr}^{95}-\mathrm{Nb}, \mathrm{Cs}^{137}$, and $\mathrm{Ce}^{144}-\mathrm{Pr}$ was relatively small; their changes in concentration across the diameter of the fuel were less than a factor of 2.5. However, $R u^{106}-R h$ was concentrated in the peripheral area of the fuel. Under the conditions of fuel irradiation, the ruthenium apparently reacted with oxygen to form a highly volatile species which migrated to the cooler outer zone of the fuel.

The redistribution of bred plutonium in the fuel was also small. Ten of the 12 areas sampled were of equal plutonium concentration, within 
the limits of analytical accuracy. An apparent $30 \%$ decrease in plutonium in two areas sampled at the outer edge of the fuel is attributed to the effects of flux depression in this zone.

d. Laser Sampling Device. A small laser attached to a microscope has been developed for use as a microsampling device. Depending on the selection of optical components and the input power to the laser, craters from 5 to $100 \mu$ in diameter can be vaporized in uranium dioxide. If a microscope cover glass is mounted 0.2 to $0.4 \mathrm{~mm}$ above the surface of the specimen and the laser is fired through it, much of the vaporized $\mathrm{UO}_{2}$ is condensed on the glass. Samples from about three nanograms to one or two micrograms can be obtained in this manner.

Vaporizations have, been carried out in both vacuum and air. There seems to be little difference in the appearance of the deposit when the craters are large, i.e., greater than $20 \mu$. In each case a small mirrorlike spot can be seen on the cover glass without the aid of magnification. Most of the material is condensed as a thin film covering an area with a diameter at least three times the diameter of the crater. In addition, some of the material is caught in the form of fine droplets. These are rarely larger than a micron in diameter.

Such samples should be useful for the examination of the composition of very small areas of metallurgical specimens. Three methods are being considered: alpha pulse height analysis, gamma spectroscopy, and neutron activation.

As a test of this technique, samples were taken from a small segment of an irradiated fuel rod. The rod was $3.8 \%$ enriched uranium dioxide, irradiated to approximately $1 \%$ burnup. A crater $50 \mu$ in diameter was made near the edge of the specimen. The weight was estimated to be about $0.5 \mu \mathrm{g}$. One drop of $0.05 \%$ collodion solution was dried on the vaporized sample on the cover glass to help hold the sample. The cover glass was then placed directly into the counting equipment. The sample was counted for $16 \mathrm{hr}$ using a silicon-surface-barrier solid-state detector. The maximum resolution obtained with this detector was $25 \mathrm{keV}$ (FWHM) on a monoenergetic alpha source.

Specimens obtained by this technique should also be adequate for gamma spectroscopy and for neutron activation. Further work is planned on all three types of analyses.

\section{Fabrication and Evaluation}

a. U-S-O System. The extent and nature of the UOS solid-solution area (see Progress Report for February 1967, ANL-7308, pp. 56-57) was investigated in more detail. Uranium disulfide $\left(U S_{1.97}\right.$ ) and uranium 
dioxide $\left(\mathrm{UO}_{2.15}\right)$ powders were blended to give nine compositions ranging from $12 \mathrm{~m} / \circ \mathrm{US}_{2}-88 \mathrm{~m} /$ o UOS through UOS to $\mathrm{UO}_{2}$, pelletized, and fired at 1450,1550 , and $1650^{\circ} \mathrm{C}$ for $3 \mathrm{hr}$ in vacuum.

At $165.0^{\circ} \mathrm{C}, \mathrm{X}$-ray and metallographic data indicated that almost $70 \mathrm{~m} / \mathrm{O} \mathrm{UO}_{2}$ is soluble in UOS, meaning that up to. $70 \%$ of the sulfur atoms in the UOS structure can be replaced by oxygen atoms. An estimated 1 to $3 \mathrm{v} / 0$ of small US particles were dispersed in equilibrium with the UOS-UO 2 solid solution. With addition of more than $70 \mathrm{~m} / \circ \mathrm{UO}_{2}$ to the UOS, a cubic phase having almost the same lattice parameter as pure $\mathrm{UO}_{2}$ occurs in equilibrium with the solid solution, suggesting only slight solubility of sulfur in $\mathrm{UO}_{2}$. In the UOS-US 2 direction, other data indicate that no more than a few percent of $U_{2}$ is soluble.in UOS.

The extensive substitution of oxygen for sulfur atoms was unexpected since $\mathrm{O}^{-2}$ ions $(r=1.32 \AA)$ are $28.2 \%$ smaller than the solvent $\mathrm{S}^{-2}$ ions $(r=1.84 \AA)$, and familiar substitution rules indicate that solubility should become restricted when the difference reaches $15 \%$. In this case, however, the tetragonal PbFCl structure of UOS $\left(a_{0}=3.844 \AA ; c_{0}=6.694 \AA\right)$ is completely layered, having like atoms arranged in planes perpendicular to the c-axis in a O-U-S-S-O-U-S-S ... sequence. The smaller oxygen ions can thus be accommodated by a contraction in the c-direction.

An analysis of the $X$-ray powder data for the solid solutions reveals a definite relationship between the UOS and $\mathrm{UO}_{2}$ structures. This relationship involves the effect of increasing oxygen substitution causing the d-spacings of the $\{110\}$ and $\{101\}$ planes of the UOS phase to approach systematically those of the $\{200\}$ and $\{111\}$ planes, respectively, of $\mathrm{UO}_{2}$ (fluorite structure, $a_{0}=5.470 \AA$ ), i.e., the cation arrangement in the UOS phase approaches identity with the cation lattice of $\mathrm{UO}_{2}$. In the case of $\mathrm{d}_{110} \rightarrow \mathrm{d}_{200}$, only a slight expansion of $\mathrm{a}_{0}(3.844 \rightarrow 3.868 \AA)$ is involved, whereas for $d_{101} \rightarrow d_{111}$ a large contraction of $c_{0}(6.694 \rightarrow 5.470 \AA)$ is additionally required. A continuous transition between the two structures is not possible since, even if a single plane of oxygen atoms was formed by complete substitution in the sulfur double layer, it would have to be translated through $a_{0} / 2$ to obtain the fluorite structure.

Room-temperature measurements showed the resistivity of the UOS solid-solution phase to have changed from that of a semiconductor to that of an insulator somewhere between the compositions having 50 and $70 \mathrm{~m} / 0$ of the solute $\mathrm{UO}_{2}$. From UOS through the $50 \mathrm{~m} / \mathrm{o} \mathrm{UO} \mathrm{U}_{2}$ solution, the resistivity varied (although not systematically) from 1.2 to $2.8 \times 10^{-2} \Omega-\mathrm{cm}$, and then jumped to $4.2 \times 10^{2} \Omega-\mathrm{cm}$ for the $70 \mathrm{~m} / 0 \mathrm{UO}_{2}$ solution (as compared to $5.2 \times 10^{2} \Omega-\mathrm{cm}$ for the pure $\mathrm{UO}_{2}$ end member). Intermediate compositions are being prepared to determine whether this is a gradual or an abrupt transition. 
Resistivity measurements by the conventional four-point probe method required silvering the ends of the pellets for adequate contact with the current-lead blocks. When a thin coating of silver was baked-on for $10 \mathrm{~min}$ at $610^{\circ} \mathrm{C}$.in vacuum, the block-to-sample interfacial resistance dropped by a factor of about 30, apparently because of the formation of an intermediate $\mathrm{Ag}_{2} \mathrm{~S}$ phase. This phase was not formed at $450^{\circ} \mathrm{C}$. Use of the improved contact increased the reproducibility of independent measurements by reducing the variance from $\pm 20 \%$ to $\pm 1 \%$.

b. Dissolution Kinetics in Liquid-metal Systems. The validity of applying the internal-friction method of analysis for oxygen of tantalum wire equilibrated with sodium to the determination of oxygen in sodium has been studied (see Progress Report for February 1967. ANL-7308, pp. 60-61). This work has been mainly concerned with accurate determination of the distribution coefficient for oxygen between tantalum and sodium. The specificity of the method (a characteristic as important as the sensitivity) has led to initiation of a study of the behavior of nitrogen in sodium systems.

Development of the proposed method for analysis of low oxygen concentrations in sodium continues to involve the equilibration, with respect to oxygen activity, of tantalum wires in liquid sodium and the subsequent measurement of the oxygen concentration in the tantalum by internal-friction techniques. The oxygen concentration in the sodium is then related to the oxygen in tantalum by the distribution coefficient (ppm $\mathrm{O}$ in $\mathrm{Ta} / \mathrm{ppmO}$ in $\mathrm{Na}$ ), which has been calculated from the best available free energy and solubility data.

The detection of significant nitrogen pickup by the tantalum wires during exposure to sodium (see ANL-7308, pp. 60-61) has led to an attempt to measure the nitrogen and carbon concentration in sodium by the same method. Since each interstitial element has a characteristic internalfriction peak in a body-centered-cubic metal, it is possible to distinguish the impurity elements and measure them simultaneously with the same wire. Because of a lack of free energy and solubility data, the distribution coefficients for nitrogen and carbon between tantalum and sodium cannot be determined. Therefore, the friction peak heights have not been quantitatively related to the concentrations of these elements in sodium.

Since the diffusivities of nitrogen and carbon in tantalum are relatively low, niobium and vanadium wires are being tested in an attempt to reduce the time required for equilibration of the impurity elements. The diffusivities of nitrogen and carbon are considerably higher in these metals than in tantalum. Based on solid-state diffusion control, the times required for $99 \%$ equilibration of the $0.25-\mathrm{mm}$-dia wires are listed in $\mathrm{T}$ able XXII. 
TABLE XXII: Equilibration Times.

\begin{tabular}{|c|c|c|c|}
\hline \multirow{2}{*}{$\begin{array}{c}\text { Wire } \\
(0.25-\mathrm{mm} \mathrm{dia})\end{array}$} & \multicolumn{3}{|c|}{$\begin{array}{c}\text { Equilibration Time in } 700^{\circ} \mathrm{C} \text { Sodium } \\
.(99 \%)(\mathrm{hr})\end{array}$} \\
\hline & Oxygen & Nitrogen & Carbon \\
\hline Tantalum & 3 & 2000 & 2500 \\
\hline Niobium & 2 & 280 & 220 \\
\hline Vanadium & 9 & .170 & 11 \\
\hline
\end{tabular}

Listed in Table XXIII are the temperatures at. which the internal-friction peaks have been identified for $0.25-\mathrm{mm}$-dia by $5.0-\mathrm{cm}$ gauge length wires of the three refractory metals.

TABLE XXIII. : Internal-friction Peak Temperatures

\begin{tabular}{|c|c|c|c|c|}
\hline \multirow{2}{*}{$\begin{array}{l}\text { Refractory } \\
\text { Metal }\end{array}$} & \multirow{2}{*}{$\begin{array}{l}\text { Frequency } \\
\quad(\text { cps })\end{array}$} & \multicolumn{3}{|c|}{$\begin{array}{l}\text { Temperature of Internal- } \\
\text { friction Peak }\left({ }^{\circ} \mathrm{C}\right)\end{array}$} \\
\hline & & Oxygen & Nitrogen & Carbon \\
\hline Tantalum & 0.45 & 132 & 323 & $332^{a}$ \\
\hline Niobium & 0.30 & 131 & 268 & 255 \\
\hline Vanadium & 0.40 & 171 & 252 & $159^{a}$ \\
\hline
\end{tabular}

${ }^{\text {aEstimated. }}$

c. Irradiation of Th-U-Pu Alloys. Six $\mathrm{Th}-\mathrm{U}$ and $\mathrm{Th}-\mathrm{U}-\mathrm{Pu}$ fuel alloys jacketed in $\mathrm{V}-20 \mathrm{w} / \mathrm{O} \mathrm{Ti}$ tubing continued under irradiation in the CP-5 reactor. The objectives of the experiment are to determine the relative swelling behavior of the fuels, the restraint characteristics of the jacket, and the maximum attainable burnup before jacket failure. Table XXIV summarizes irradiation variables for these metal fuel experiments.

TABLE XXIV. Status of Metal Fuel Irradiations in CP- 5

\begin{tabular}{|c|c|c|c|c|c|c|}
\hline \multirow{3}{*}{$\begin{array}{l}\text { Specimen } \\
\text { Number }\end{array}$} & \multicolumn{2}{|c|}{ Design Parameters ${ }^{a}$} & \multirow{3}{*}{$\underset{(\mathrm{kW} / \mathrm{ft})}{\operatorname{Max}}$} & \multirow{3}{*}{$\begin{array}{l}\text { Max Cladding } \\
\text { Temp }\left({ }^{\circ} \mathrm{C}\right)\end{array}$} & \multirow{2}{*}{\multicolumn{2}{|c|}{ Burnup to Date }} \\
\hline & \multirow{2}{*}{$\begin{array}{c}\text { Fuel } \\
\text { Composition } \\
(w / o)\end{array}$} & \multirow{2}{*}{$\begin{array}{c}\text { Effective } \\
\text { Density } \\
(\%)\end{array}$} & & & & \\
\hline & & & & & $a / o(U+P u)$ & fiss $/ \mathrm{cc} \times 10^{-20^{b}}$ \\
\hline $1 N 16$ & $\mathrm{Th}-20 \mathrm{U}$ & 74.7 & 8.7. & 590 & 23.1 & 11.1 \\
\hline $4 \mathrm{~N} 19$ & $\mathrm{Th}-20 \mathrm{U}$ & 74.0 & 8.7. & 560 & 23.1 & 11.1 \\
\hline $2 \mathrm{~N} 17$ & $T h-10 P u-10 U$ & 74.1 & 9.2 & 590 & 26.2 & 12.3 \\
\hline $5 N 20$ & $T h-10 \mathrm{Pu}-10 \mathrm{U}$ & 73.0 & 9.2 & 590. & 26.2 & 12.3 \\
\hline $3 N 18$ & $T h-10 P u-20 U$ & 73.5 & 8.7 & 560 & 15.6 & 11.4 \\
\hline $6 \mathrm{~N} 21$ & $T h-10 \mathrm{Pu}-20 \mathrm{U}$ & 73.5 & 8.7 & 560 & 15.6 & 11.4 \\
\hline
\end{tabular}

${ }^{\mathrm{a}}$ All specimens are sodium-bonded to $\mathrm{V}-20 \mathrm{w} / \mathrm{o}$ Ti jackets, of $0.198-\mathrm{in}$. OD with a wall thickness of $0.015 \mathrm{in.}$.

${ }^{b}$ Based on effective density. 


\section{d. Thermal Stability of Plutonium Ceramics}

(i) $\mathrm{PuO}_{2}$ Evaporation. The results of experiments on the determination of oxygen-to-metal (O/M) atomic ratios in hypostoichiometric $(\mathrm{U}, \mathrm{Pu}) \mathrm{O}_{2-\mathrm{x}}$ compositions, have been reported (see Progress Report for February 1967, ANL-7308, pp. 55-56). Heat treatment at $1100^{\circ} \mathrm{C}$ in helium-1 $\mathrm{v} / \mathrm{o} \mathrm{O}_{2}$ followed by equilibration at $850^{\circ} \mathrm{C}$ in a 10 to $1 \mathrm{CO} / \mathrm{CO}_{2}$ volume mixture apparently produced a final $\mathrm{O} / \mathrm{M}$ ratio of 2.00 . Measurements of the vapor pressure of hypostoichiometric $\mathrm{PuO}_{2}-\mathrm{x}$ have now been completed. Although it has been indicated (see Progress Report for January 1967, ANL-7302, p. 65) that rhenium Knudsen cells might be used for subsequent measurements of vapor pressure, all measurements have so far been made with a tungsten cell; iridium, although previously demonstrated to be compatible with $\mathrm{PuO}_{2}$, has such a high vapor pressure above $2100^{\circ} \mathrm{K}$ that the use of iridium cells is impracticable at the temperatures required for the $\mathrm{PuO}_{2}$ work.

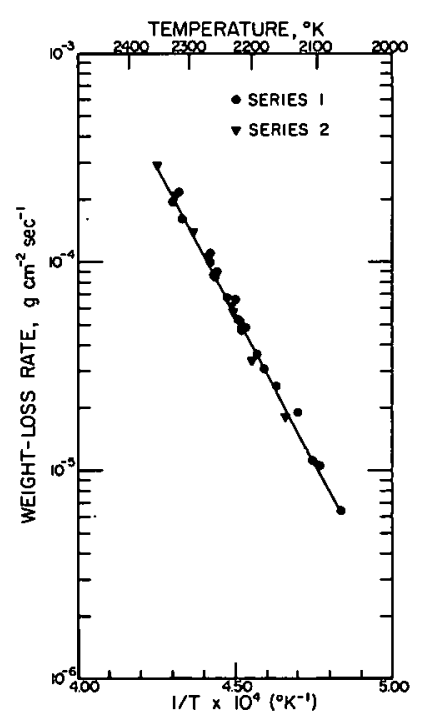

Fig. 17

Weight Losses per Second of $\mathrm{PuO}_{1.825}$ and $\mathrm{PuO}_{1.875}$ in Knudsen-cell Runs. (The respective final $\mathrm{O} / \mathrm{M}$ ratios are 1.82 and 1.79.)

Figure 17 shows the results of two series of Knudsen-cell runs on specimens with initial oxygento-metal $(\mathrm{O} / \mathrm{M})$ ratios of 1.825 (Series 1 ) and 1.875 (Series 2 ), respectively. The $\mathrm{O} / \mathrm{M}$ ratio after evaporation of the former was 1.820 and that of the latter was 1.794. Linear evaporation rates obtained for all of the runs in Series 1. In the first few high-temperature runs in Series 2, however, nonlinearity of the evaporation rates indicated that the composition of this specimen was changing. The data given for Series 2 represent runs made after the rates became linear, and presumably represent evaporation of a composition corresponding to the final $O / M$ ratio of 1.794 .

The small composition difference between the two specimens does not cause a significant difference in the rates of evaporation of each. Furthermore, the measured weight-loss rates were linear and the final compositions almost the same. The evidence thus indicates that the congruently evaporating composition has an $\mathrm{O} / \mathrm{M}$ ratio close to 1.80 in the temperature range from 2070 to $2360^{\circ} \mathrm{K}$.

\section{Techniques of Fabrication and Testing}

a. Ultrasonic Instrument and Transducer Development. Fabrication of two transducer probes with a PZT-4 piezoelectric element was completed. The two elements are identical except that the tungsten backing of one is $62 \%$ dense and of the second only $52 \%$ dense. Evaluation of these probes has started. 
b. Development of a Neutron Image Intensification System. The neutron television system incorporating a neutron-image intensifier tube (see Progress Report for April 1966, ANL-7204, p. 52) is now being evaluated for use in studying the process of casting heavy metals. X-ray motionstudy techniques can be used ${ }^{14}$ for casting studies, but $\mathrm{X}$-radiation transmission for reasonable thicknesses of reactor fuels of interest, such as uranium or plutonium, would be relatively low. The neutron motion study of castings essentially complements the $\mathrm{X}$-ray work by extending the range of metals for which this technique may be useful.

Prototype casting studies were made at Juggernaut reactor with the neutron television system. A low-melting point alloy, Wood's metal $(50 \% \mathrm{Bi}, 25 \% \mathrm{~Pb}, 12.5 \% \mathrm{Sn}, 12.5 \% \mathrm{Cd})$, was chosen for the initial tests because the thermal-neutron transmission through that material approximates that through $\mathrm{U}^{235}$.

Figure 18 shows a result of one of the casting study trials. Wood's metal was poured into an aluminum block in which a $0.63-\mathrm{cm}$-dia mold pattern was formed. Every other frame from a $16-\mathrm{mm}$ motion-picture recording of the neutron television monitor is shown. The metal begins to enter the mold from the top in frame 1, runs horizontally in frames 2 and 3 , begins to drop again into the vertical member of the mold in frame 3 , and

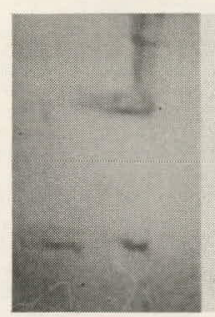

1

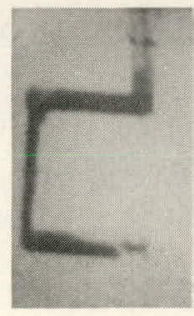

6

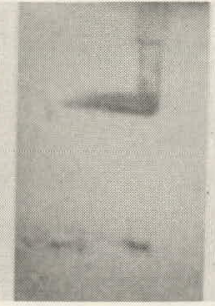

2

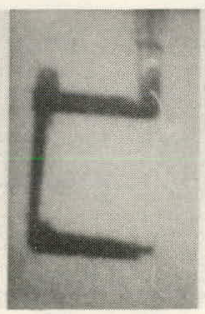

7

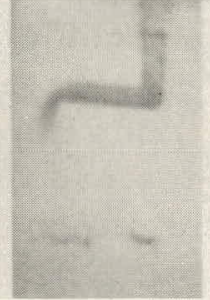

3

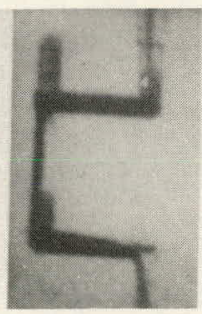

8

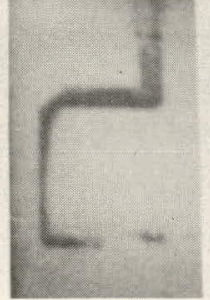

4

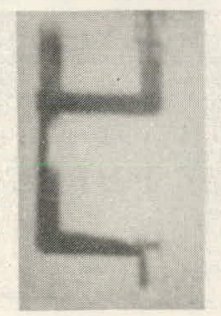

9

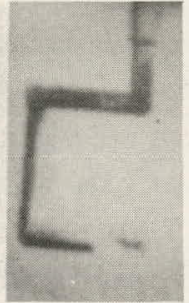

5

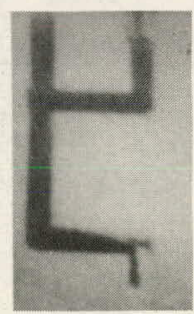

10

Fig. 18. Individual Frames of a Motion-picture Recording Showing a Televised Neutron Transmission Image of the Casting of Wood's Metal into an Aluminum Mold. The sequence begins in frame 1, with the molten metal entering from the top. The total time represented by the ten frames shown is less than one second.

14Rose, H., Dyke, W. P., Grundhauser, F. J., and Barbour, J. P., X-ray Movies of Metal Casting, presented at the 1966 Spring Convention of the Society for Nondestructive Testing, Los Angeles, California, March 1966; see Materials Evaluation 24, 92 (February 1966). 
then extends horizontally again beginning in frame 4 . Note how the vertical section fills initially just on one side (frames 4-6) and then begins to fill from the bottom in frames 7-10. Further analysis of these casting pictures is now in progress.

c. Determination of Elastic Moduli of High-temperature Materials by Ultrasonics. Ultrasonic measurements were made with a specially machined bar of Type 304 stainless steel at temperatures up to $1000^{\circ} \mathrm{C}$ in order to determine its elastic properties as a function of temperature (see Progress Report for November 1966, ANL-7279, p. 58). The difference in test temperature between the ends of the index region was kept less then $10^{\circ} \mathrm{C}$. Since then some preliminary work was undertaken to develop a means of using shorter measurement samples than had been initially required. A buffer-rod technique is now being used.

Because common ultrasonic couplants will not withstand the high temperatures, they cannot be used. A forced mechanical bond approach was selected. The bonding surfaces have to be flat and polished to a $3 \mu$ finish. Threads placed on the buffer and sample, to clean up the reflections, were used to force the two surfaces together. A coupling was screwed on the buffer and the sample screwed into it. A good mechanical bond was obtained.

Initial tests with this technique were made with an ASTM 6061 aluminum buffer and sample. Temperatures close to the melting point $\left(660^{\circ} \mathrm{C}\right)$ were obtained from thermocouple readings on the top of the sample. Sample length was only $7.5 \mathrm{~cm}$, instead of about $46 \mathrm{~cm}$ as formerly required. The top configuration did not change. Trailing pulse echoes were measurable to temperatures above $600^{\circ} \mathrm{C}$. Work on stainless steel is now in progress.

d. Measurement of Thermal Conductivity of Irradiated Fuel as a Function of Burnup and Temperature. Following completion of the calibration of the system for measuring the thermal properties of fuel elements (see Progress Report for March 1967, ANL-7317, p. 28) the thermal properties of unirradiated EBR-II driver fuel are being measured.

\section{Engineering Development}

1. Development of Master-Slave Manipulator Systems

a. Electric Master-Slave Manipulator, Mark E4A. An effort is being made to improve the radiation resistance of the Mark E4A slave arm. At the present time, the first gear and synchro in the servo drive unit appear to be the major items limiting the resistance. The motors, tachometers, and the lubricants used throughout the slave arm are good to dosages of $5 \times 10^{8} \mathrm{R}$ or better. All other components, except the external wiring, are resistant to much higher dosages. 
A low-inertia, hardened-steel $\left(R_{c} 55\right)$ first gear has been designed to replace the formica gear now in use. This gear will increase the effective inertia of the manipulator, but only by about $2 \%$. An aluminum gear had been tried previously, but, due to oxide formation and servo-motor jitter., these wore out very quickly. A few of the new gears and hardened pinions are on order. After these are received and installed, a life test will be run to determine their suitability.

A few synchros will be sent out next month for rewiring with Class $\mathrm{H}$ insulation. All components of a complete servo drive unit will then be irradiated to determine the maximum dosage they can withstand.

b. Low-inertia Servo Motor for Manipulators. A special, high torque-to-inertia servo motor has been designed, detailed, and parts are on order. This 2-pole, 2-phase motor uses a rotor with an annealed-steel core and a copper sleeve. The motor was designed to have the following characteristics:

$\begin{array}{ll}\text { Synchronous speed } & 3600 \mathrm{rpm} \\ \text { Stall torque (max) } & 9.6 \mathrm{in.}-\mathrm{lb} \\ \text { Rotor inertia } & 0.036 \mathrm{lb}-\mathrm{in} .^{2} \\ \text { Max input power } & 560 \mathrm{~W} \\ \text { Mechanical time constant } & 3.63 \mathrm{msec} \\ \text { Cooling required (air) } & 17 \mathrm{~cm} \\ \text { Pressure drop in motor } & 0.8 \mathrm{psi}\end{array}$

With these characteristics, the motor would be suitable for a l00-1b capacity manipulator such as the Mark E4B, with a synchronous speed at the wrist joint of $36 \mathrm{in./sec}$. The rotor inertia, referred to the manipulator wrist joint, is equivalent to a 4-1b mass at the wrist joint. This is about the same as the inertia of the motors used on the 50-1b capacity Mark-E4A manipulator.

\section{Heat Transfer and Fluid Flow}

a. Niobium-1\% Zirconium Loop. A facility has been built to investigate the heat transfer and two-phase flow characteristics of boiling sodium to a temperature of $2100^{\circ} \mathrm{F}$ and a pressure of approximately 8 atm. Among the variables to be investigated are boiling heat flux and temperature difference up to the critical-flux occurrence, boiling and adiabatic two-phase pressure losses, vapor volume fraction, boiling stability parameters, and ultimately the transient. behavior of some of these same quantities.

Flowmeter calibrations have been completed for sodium temperatures up to $1200^{\circ} \mathrm{F}$. Several minor additions to the $\mathrm{Nb}-1 \% \mathrm{Zr}$ loop have been made in preparation for runs above $1200^{\circ} \mathrm{F}$. 
b: Heater Experiments

(i) Electron-bombardment Heater (EBH) Experiment. As mentioned in previous progress reports, the original tests have been terminated following satisfactory operation; further EBH tests will be conducted in the new EBH test facility that is being constructed (see Progress Report for January 1967, ANL-7302, p. 71). This facility will be used to test heaters to their maximum heat-flux capabilities before they are installed in the $\mathrm{Nb}-1 \% \mathrm{Zr}$ loop.

\section{c. Heat Transfer in Double-pipe Heat Exchangers}

(i) Countercurrent Turbulent Liquid-metal Flow. Experimentation with the second heat-exchanger test section was completed. Plans were completed for experiments with the third test section.

Computations for the mathematically degenerate case of equal-heat-capacity flowrates (see Progress Report for February 1967 , ANL-7308, p. 68) have been extended for the purpose of studying walltemperature distributions along the heat-exchanger length.

(ii) Nonsymmetrical Geometries. Construction of the small heat-transfer loop for the purpose of performing experiments with sodium in model heat exchangers is about 50\% complete. Fabrication of the first test section, a double-pipe heat exchanger designed to obtain data relating eccentricity of the annular phase on overall heat-transfer rates, is about $60 \%$ complete.

(iii) Liquid-metal-heated Steam Generators. An analysis of a simple model of a liquid-metal-heated steam generator (see Progress Report for January 1967, ANL-7302, p. 72) has been completed. Computations are being made for comparing the predictions of the analysis with those of current engineering-design methods.

\section{Mechanics of Matcrials}

a. Core Structural Dynamics. To study experimentally the axialflow-induced vibration of simulated fast-reactor fuel elements, methods of measuring fuel-rod motion are needed. The initial effort to build a device which measures the motion of a peripheral rod has been successful. The inductive device (sensitive to $1 \times 10^{-14}-$ in. displacement) discussed previously (see Progress Report for January 1967, ANL-7302, p. 73) was used to determine the response of a single rod. Water flowing axially at $10 \mathrm{ft} / \mathrm{sec}$ over a 36-in.-long, 1/2-in.-dia polystyrene rod with pinnedpinned ends produced random peak-to-peak displacements of as much as 
$45 \times 10^{-3}$ in. The displacement apparently: results from repetitive excitation with varying amplitude and duration. In other words, random transverse-pressure fluctuations caused by turbulent flow could be exciting the rod. Two transducers perpendicular to each other indicate rod motion of the same order of magnitude. Thus it can be deduced that the transverse-pressure fluctuations (although applied at differing times) have rms magnitudes which are independent of radial orientation.

Spectrum analysis of the displacement data indicates three frequency bands of rod motion. The major amount of motion occurs at a frequency which corresponds to the first natural resonant frequency of the rod in water. The other two bands of significant amplitude could correspond to second and third mode. However, the second-mode frequency should be lower than that where the experimental peak occurs and the third-mode frequency should be higher. This deviation may be explained by the effect of the axial component of water flow, by the pump-induced vibration of the present test section, or by nonuniformities of the present specimen and specimen-mounting method.

As well as clarification of the peripheral rod motion, the following subjects are being studied: (a) reduction of the pump-induced vibration of the test section; application of vibration-isolation mountings and flexible piping components should be adequate, (b) methods and instrumentation for measuring and analyzing the random transverse pressure field due to turbulent flow and the loop characteristics; cross-and auto-correlation techniques applied to data procured with miniature-crystal pressure transducers appear promising, and (c) methods of monitoring the motion of a rod interior to a bundle in axial water flow; semiconductor strain gauges and miniature accelerometers are being investigated.

\section{Chemistry and Chemical Separations}

\section{Fluoride Volatility Processes}

a. Recovery of Uranium and Plutonium from Low-enrichment Fuels: Laboratory Support Work.

(i) Fluorination of $\mathrm{UO}_{2}-\mathrm{PuO}_{2}-$ Fission Product Pellets. Development studies are being performed in a 2-in.-dia fluid-bed reactor to establish optimum conditions for the recovery of uranium and plutonium from $\mathrm{UO}_{2}-\mathrm{PuO}_{2}$ pellets containing fission products. In the process currently under study, $\mathrm{BrF}_{5}$ is used as a selective fluorinating agent for conversion of uranium oxides in uranium-plutonium mixtures to volatile UF 6 . In this reaction, plutonium is converted to nonvolatile $\mathrm{PuF}_{4}$. Recovery of plutonium as volatile $\mathrm{PuF}_{6}$ is effected in a subsequent step by reaction of $\mathrm{PuF}_{4}$ with fluorine. A recent experiment (Purse-17) was performed to evaluate the use of $50 \mathrm{v} / \mathrm{o}$ fluorine in nitrogen in the plutonium recovery step instead of $90 \mathrm{v} / \mathrm{o}$ fluorine as used previously (see, for example, Progress Report for February 1967 , ANL-7308, pp. $71-73$ ). 
The charge to the fluid-bed reactor in run Purse-17 consisted of $650 \mathrm{~g}$ of $0.5 \mathrm{w} / \mathrm{o} \mathrm{PuO}_{2}-\mathrm{UO}_{2}$-fission product pellets and $1100 \mathrm{~g}$ of alumina containing $0.6 \mathrm{~g} \mathrm{CsF}, 0.15 \mathrm{~g} \mathrm{RbF}$, and $0.5 \mathrm{~g} \mathrm{NpO}_{2}$. The processing sequence consisted of the following: oxidation of the pellets for $4 \mathrm{hr}$ at $450^{\circ} \mathrm{C}$ with $20 \mathrm{v} / 0$ oxygen, fluorination of the uranium to $\mathrm{UF}_{6}$ with $10 \mathrm{v} / 0$ $\mathrm{BrF}_{5}$ at $300^{\circ} \mathrm{C}$ for $2 \mathrm{hr}$, and recycle-fluorination of the plutonium to $\mathrm{PuF}_{6}$ with $50 \mathrm{v} / 0$ fluorine for $5 \mathrm{hr}$ at $300^{\circ} \mathrm{C}, 5 \mathrm{hr}$ while the reactor temperatures was increased from 300 to $550^{\circ} \mathrm{C}$, and $5 \mathrm{hr}$ at $550^{\circ} \mathrm{C}$.

The final alumina bed contained $<0.001 \mathrm{w} / \mathrm{o}$ uranium, $0.009 \mathrm{w} / \mathrm{o}$ plutonium, and $0.003 \mathrm{w} / \mathrm{o}$ neptunium. These results are nearly identical to those obtained in previous experiments using $90 \mathrm{v} / 0$ fluorine in nitrogen for the plutonium recovery step (see ANL-7308, pp. 71-73). Therefore, it appears that the concentration of fluorine can be varied within the range 50 to $90 \mathrm{v} / 0$ in nitrogen without affecting the removal of plutonium from the alumina bed by fluorination.

(ii) Purification of Plutonium Streams. In the flowsheet being studied for the fluoride volatility processing of oxide fuels, separation of plutonium is achieved by fluorination of $\mathrm{PuF}_{4}$ to $\mathrm{PuF}_{6}$ with fluorine. This $\mathrm{PuF}_{6}$ stream contains small quantities of uranium, neptunium, and certain fission products which form volatile fluorides, and therefore the stream must be processed further for the preparation of a purified plutonium product. A laboratory-scale experimental program is under way to explore several schemes for the purification of the $\mathrm{PuF}_{6}$ process stream. Two purification schemes are being explored. One method involves the selective reduction of $\mathrm{PuF}_{6}$ to $\mathrm{PuF}_{4}$ by $\mathrm{BrF}_{3}$. The second method (not reported this period) employs separation of $\mathrm{PuF}_{6}$ from fission product compounds of low volatility by sublimation of $\mathrm{PuF}_{6}$.

The results of initial experiments evaluating the use of $\mathrm{BrF}_{3}$ as a selective reductant for $\mathrm{PuF}_{6}$ have been reported (see Progress Report for March 1967, ANL-7317, p. 85). These experiments, performed with mixtures of fluorides containing gram quantities of $\mathrm{UF}_{6}, \mathrm{NpF}_{6}, \mathrm{SbF}_{5}$, $\mathrm{NbF}_{5}$, and $\mathrm{RuF}_{5}$, indicated that separation of uranium, antimony, and niobium from plutonium was essentially complete, while separation of ruthenium was only achieved in a subsequent step involving fluorination of the solid $\mathrm{PuF}_{4}$ with $\mathrm{BrF}_{5}$ at $300^{\circ} \mathrm{C}$. Recent analytical data have shown that neptunium tends to accompany the $\mathrm{PuF}_{4}$ and that no significant separation is achieved in either the reduction or fluorination steps. Additional experiments with tracer quantities of niobium $\left(\mathrm{Nb}^{95}\right)$ and ruthenium $\left(\mathrm{Ru}^{106}\right)$ showed very poor separation of these elements from plutonium. On the basis of these results, it appears that this technique is not effective in removing fission product elements from plutonium and no further development work on this method is planned.

In other work, the possibility of removing ruthenium from the $\mathrm{PuF}_{6}$ process stream by selective sorption of $\mathrm{RuF}_{5}$ on alkaline earth 
fluorides is being investigated. A series of three experiments was performed to determine the effectiveness of $\mathrm{BaF}_{2}, \mathrm{CaF}_{2}$, and $\mathrm{MgF}_{2}$ as sorbents for $R_{4 F_{5}}$. In these experiments a mixture of $U F_{6}$ (a stand-in for $P u F_{6}$ ) and $\mathrm{RuF}_{5}$ (containing $\mathrm{Ru}^{106}$ as a tracer) in nitrogen was passed through a trap containing $10 \mathrm{~g}$ of the alkaline earth fluoride at 100 to $150^{\circ} \mathrm{C}$, then through a $\mathrm{NaF}$ trap at $100^{\circ} \mathrm{C}$ to remove the $\mathrm{UF}_{6}$, and finally through a cold trap at $-78^{\circ} \mathrm{C}$. It was observed in these experiments that the effectiveness of the fluorides for $\mathrm{RuF}_{5}$ sorption decreases in the order $\mathrm{BaF}_{2}, \mathrm{CaF}_{2}, \mathrm{MgF} \mathrm{F}_{2}$. The respective decontamination factors were 374,55 , and 9 . The evaluation of plutonium-purification methods is being.continued.

(iii) Neptunium Fluoride Chemistry. Laboratory-scale studies are being carried out to determine the behavior of neptunium hexafluoride in chemical reactions of interest to its recovery. Current studies concern an investigation of the reaction between $\mathrm{NaF}$ and $\mathrm{NpF}_{6}$ with particular emphasis on identifying the nature and properties of the reaction product. An experiment was performed in which $\mathrm{NaF}$ was contacted with $\mathrm{NpF}_{6}$ (250$300 \mathrm{~mm} \mathrm{Hg}$ ) at $150^{\circ} \mathrm{C}$. The product appeared as loose, fluffy particles, pale-violet in color. The weight increase of the solid phase in the reaction of $\mathrm{NpF}_{6}$. with $\mathrm{NaF}$ indicated that three moles of $\mathrm{NaF}$ are associated with one mole of neptunium in the complex. It was not possible to establish the valence state of neptunium in the product. Further experiments to obtain this information through absorption spectra of the product are planned.

\section{b. Recovery of Uranium and Plutonium from Low-enrichment} Fuels: Engineering Work

(i) Process Development Studies for Uranium Dioxide Fuels. Engineering-scale studies are being performed in a 3-in.-dia fluid-bed reactor facility to determine the effects of important process variables on the fluorination of $\mathrm{UO}_{2}$ fuels with $\mathrm{BrF}_{5}$. The current program involves a series of eight statistically designed experiments to measure the effects of six independent variables on $\mathrm{UF}_{6}$ production rate, $\mathrm{BrF}_{5}$ utilization, off-gas composition, and uranium removal from the fluid bed. The fourth experiment (run BRF5-6) in this series has been completed. In this experiment $2.2 \mathrm{~kg}$ of $\mathrm{UO}_{2}$ in an alumina fluid bed was oxidized to $\mathrm{U}_{3} \mathrm{O}_{8}$ fines by reaction with $19 \mathrm{v} / \mathrm{o}$ oxygen in nitrogen for $6 \mathrm{hr}$ at $450^{\circ} \mathrm{C}$. Fluorination of the $\mathrm{U}_{3} \mathrm{O}_{8}$ fines was carried out using $2 \mathrm{l} \mathrm{v} / \mathrm{o} \mathrm{BrF}_{5}$ in nitrogen for $2 \mathrm{hr}$ at $300^{\circ} \mathrm{C}$.

The course of the fluorination reaction was followed by continuous analysis of the oxygen content of the off-gas stream. On the basis of the oxygen analysis it was observed that the $\mathrm{UF}_{6}$ production rate

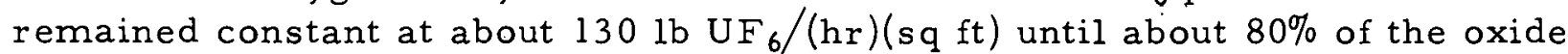
was fluorinated. A $\mathrm{BrF}_{5}$ utilization efficiency of $40 \%$ was observed during the constant rate period. The final alumina bed at the end of the fluorination step contained no agglomerates or unreacted oxide, and was a free-flowing material. 
(ii) Fluid-bed Studies with Irradiated Fuels. During the past twelve months a series of experiments were performed in al $\frac{1}{2}$-in. - dia fluidbed reactor to determine the distribution of fission products during the processing of highly irrradiated $\mathrm{UO}_{2}$ fuel by fluoride volatility techniques. Two processing schemes were used: (1) two-zone oxidation-fluorination at $460^{\circ} \mathrm{C}$, followed by direct fluorination with $90 . \mathrm{v} / 0$ fluorine at 450 to $550^{\circ} \mathrm{C}$ (see Progress Report for May 1966, ANL-7219, p. 52); (2) oxidation of the fuel with $20 \mathrm{v} / 0$ oxygen at $400^{\circ} \mathrm{C}$, fluorination of the oxidized fuel with $10 \mathrm{v} / \mathrm{o}$ $\mathrm{BrF}_{5}$ at $300^{\circ} \mathrm{C}$, and fluorination with $90 \mathrm{v} / 0$ fluorine for $10 \mathrm{hr}$ as the reactor temperature was increased from 300 to $550^{\circ} \mathrm{C}$ (see Progress Report for February 1967, ANL-7308, pp. 75-76). The results of the experimental runs which have been completed thus far in this program have been analyzed to provide an insight into the behavior of ruthenium in the process:

The results of the comprehensive analysis suggest that:

1. Treatment of irradiated $\mathrm{UO}_{2}$ by a process involving two-zone oxidation-fluorination followed by recycle fluorination produces $\mathrm{RuF}_{6}$ and either $\mathrm{RuF}_{5}$ or $\mathrm{RuOF}_{4}$, or both. The ruthenium fluoride species are relatively stable as indicated by the virtual absence of ruthenium deposit in a nickel-ball trap maintained at $150^{\circ} \mathrm{C}$.

2. Only a trace amount of ruthenium is volatilized during oxidation of $\mathrm{UO}_{2}$ fuel at $450^{\circ} \mathrm{C}$.

3. In the process based on the use of $\mathrm{BrF}_{5}$, the bulk of the ruthenium is volatilized during the $\mathrm{BrF}_{5}$ fluorination step. The volatile ruthenium compound is not completely removed from the process gas stream by sorption on $\mathrm{NaF}$ pellets at $400^{\circ} \mathrm{C}$. The ruthenium compound is effectively removed from the gas stream by activated alumina and soda lime.

4. The volatile ruthenium compounds which are formed in the $P_{4} F_{6}$ volatilization step are probably $R_{u F}, R_{u O F_{6}}$, and $R_{u F}$. 
IV. ADVANCED SYSTEMS.RESEARCH AND DEVELOPMENT

A. Argonne Advanced Research Reactor (AARR)

1. General

The primary-heat-exchanger bid package was sent to prospective vendors; bids are due in June. The primary-pump proposals have been received and are being reviewed. The permanent-beryllium-reflector bid package has been sent out for bid. The control-rod guide-assembly proposals were received and àre being reviewed. The reactor-vessel subcontract was negotiated and is awaiting AEC approval.

Answers to questions by DRL on the PSAR Supplemient 2 were trans mitted to the AEC.

\section{Containment Potential of the Primary Coolant System}

On the basis of the preliminary design, the containment potential of - major components of the primary coolant system has been investigated. Table XXV shows the dimensions, mechanical properties; bursting pressures, and strain energies of the major components. The bursting pressure and the sum of the strain energies of the major components of the primary coolant system are $5000 \mathrm{psi}$ and $524 \mathrm{MW}-\mathrm{sec}$, respectively. The primary coolant system will rupture at a lower pressure than the pressure vessel, but will require more energy.

TABLE XXV. Properties of the AARR Primary Coolant System

\begin{tabular}{|c|c|c|c|c|c|c|c|c|c|}
\hline \multirow{2}{*}{$\begin{array}{l}\text { Part of } \\
\text { System }\end{array}$} & \multicolumn{3}{|c|}{ Size } & \multirow{2}{*}{$\begin{array}{c}\because \\
\text { Material }\end{array}$} & \multirow{2}{*}{$\begin{array}{l}\text { Ultimate } \\
\text { Strain }\end{array}$} & \multirow{2}{*}{$\begin{array}{c}\vdots \\
\text { Bursting } \\
\text { Pressure } \\
\text { (psi) }\end{array}$} & \multirow{2}{*}{$\begin{array}{l}\text { Strain } \\
\text { Energy at } \\
\text { Bursting } \\
\text { Pressure } \\
\text { (MW-sec) }\end{array}$} & \multirow{2}{*}{$\begin{array}{c}\text { Incremental } \\
\text { Volume at } \\
5000 \mathrm{psi} \\
\left(\mathrm{ft}^{3}\right)\end{array}$} & \multirow{2}{*}{$\begin{array}{c}\text { Strain } \\
\text { Energy at } \\
5000 \text { psi } \\
(\mathrm{MW}-\mathrm{sec})\end{array}$} \\
\hline & $\begin{array}{c}\text { Inside } \\
\text { Diameter } \\
\text { (in.) }\end{array}$ & $\begin{array}{l}\text { Wall } \\
\text { (in.) }\end{array}$ & $\begin{array}{c}\text { Volume } \\
\left(\mathrm{ft}^{3}\right)\end{array}$ & & & & & & \\
\hline $\begin{array}{l}\text { Heat- } \\
\text { exchanger } \\
\text { shell }\end{array}$ & 68 & $\cdot 2.00$ & 860 & $\begin{array}{l}\text { Carbon } \\
\text { steel }\end{array}$ & 0.22 & 5000 & 214 & 272 & 214 \\
\hline Fipe & 22.064 & 0.968 & 1040 & 304 SS & 0.65 & 5950 & 1400 & 346 & 302 \\
\hline Pipe & 16.5 & 0.750 & 35 & 304 SS & 0.65 & 6200 & 49 & 8.76 & 7.7 \\
\hline Total & & & & & : & : & $: 1663$ & 626.76 & 523.7 \\
\hline
\end{tabular}

As indicated in the Appendix E of the PSAR ${ }^{15}$ (see also Progress Report for January 1967, ANL-7302, pp. 79-82), for an accidental nuclear excursion of $163 \mathrm{MW}$-sec followed by a rapid metal-water reaction (core only.) of $1300 \mathrm{MW}-\mathrm{sec}$, the energy imparted to the vessel would be about $190 \mathrm{MW}-\mathrm{sec}$, and the pressure in the reactor vessel would be 4270 psi. Calculation shows

15Appendices to the Preliminary, Safety Analysis Report on the AARR, Approval Cöpy, Appendix E, "Reactor .Vessel Containment Potential,". Vol. II (March 31, 1966, Revised December 9, 1966). 
that this excursion would deposit an additional $34 \mathrm{MW}-\mathrm{sec}$ of strain energy in the primary coolant system as the pressure is equalized; the pressure after equalization would be $3300 \mathrm{psi}$. The analysis is conservative, since no credit is taken for any pressure reduction caused by the operation of the pressure-relief system.

If the metal-water reaction occurs slowly or is delayed, then the pressure vessel and the primary coolant system will deform simultaneously. Calculation shows that for this type

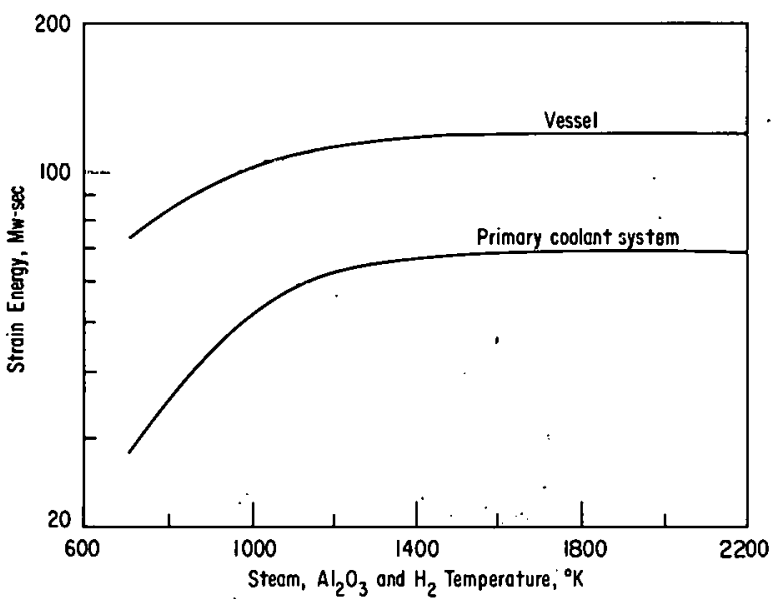

Fig. 19. Maximum Energy that Could Be Imparted to AARR Vessel and Primary Coolant System after Accidental Nuclear Excursion: of 163-MW-sec Followed by a Slow 1300-MW-sec Metal-Water Reaction of reaction the maximum energy that could possibly be imparted to the reactor vessel is about $120 \mathrm{MW}-\mathrm{sec}$, and to the primary coolant system about $71 \mathrm{MW}-\mathrm{sec}$. The maximum pressure is about $3740 \mathrm{psi}$ and the steam temperature is $2000^{\circ} \mathrm{K}$. Figure 19 shows the strain energy deposited on the pressure vessel and the primary coolant system at different steam temperatures. Again, no credit is taken for pressure relief.

a. Computer Program. The computer program for the metalwater reaction is still being programmed. When the original version of the program was programmed and tested, the results did not converge.

The same type of difficulty also occurred in the manual computation. Because the iteration method is not satisfactory, a different technique is being used.

\section{Instrumentation and Control--Flow-coastdown Dynamics}

To determine plant safety if utility electricity is interrupted, the behavior of AARR after loss of coolant pumping power has been studied. On the basis of the flow coastdown estimated previously (see Progress Report for March 1967, ANL-7317, pp. 94-95), the core kinetic and thermal responses to flow coastdown were evaluated.

a. Core Response to Flow Coastdown. The prime concern is the degree to which the core is protected if only the safety system responds to an excessive ratio of flux to flow $(\phi / F)$, omitting any prior action by the system for control of $\phi / F$.

(i) Description of Mathematical Model. The core kinetic and thermal responses to flow coastdown were evaluated by using flow versus time data (see Progress Report for March 1967, ANL-7317, pp. 95-98) as 
input to the analog model of the High Flux Isotope Reactor (HFIR). Because the HFIR analog model could be set up readily, these first studies were conducted at ORNL. Slight changes were made in the HFIR model to reflect the differences between AARR and the HFIR cores. The changes made, which were basically in the form of new constants in some of the describing equations rather than changes in the equations themselves, were: (a) hot-channel coolant velocity was changed from 42.4 to $50.0 \mathrm{ft} / \mathrm{sec}$, (b) the "target annulus" and "target section" simulation in the HFIR model were changed to simulate the single bulk-coolant region in the AARR internal thermal column (bulk coolant velocity also was reduced to $4 \mathrm{ft} / \mathrm{sec}$ ), and (c) the incipient boiling heat flux $\left(\phi_{\mathrm{B}}\right)$ at the hot spot was effectively not simulated in these coastdown studies.

Table C-3 in the PSAR ${ }^{16}$ cites the pertinent core-dynamics parameters that change significantly during the core cycle. The parameters changed in this study from "beginning of life" (B.L.) to "end of life" (E.L.) were: (a) fuel-metal temperature coefficient of reactivity (value at E.L. = $1 / 2$ value at B.L.), (b) core-coolant (moderator) temperature coefficient (value at E.L. = $1 / 2$ value at B.L.), (c) effective film coefficient at hot spot (reduces at E.L. due to oxide-scale buildup), (d) prompt-neutron lifetime (value at E.L. = 2.times value at B.L.), and (e) shim-safety plate differential worth. The variations of the first four items were used as described in the PSAR. The shim-safety plate differential worth (for initial insertion) decreases monotonically during core life because the plates are continually being withdrawn to maintain a $100-\mathrm{MW}$ power level. In contrast, however, the amount of reactivity available for normal shutdown gradually increases during the core cycle. The first effect was simulated in this study, but the latter was not. Differential shim-safety plate worths used in this study were $\$ 1.07$ in. (assumed constant during stroke) at the beginning of life, and worth increases from $\$ 0.11 /$ in. to $\$ 1.07$ /in. at the end of life.

The total reactivity insertion upon scram was considered constant, with a value of. $-8.3 \% \Delta \mathrm{k} / \mathrm{k}(\$ 11.6)$ at both beginning and end of life. This value of reactivity insertion approximates that available after operating a fresh core 1 day at $100 \mathrm{MW}$. The total safety-plate delatching time, i.e., the time required to initiate shim-safety plate motion upon reaching the $\phi / F$ trip was assumed to be $15 \mathrm{msec}$. The time simulated for plate insertion was $\sim 100$ msec.

Two cases of flow versus time (see Progress Report for March 1967, ANL-7317, pp. 98-99) were used in this study: (1) coastdown with no pony motur(s) and (2) coastdown with one pony motor. These curves were fitted with a multisegment function generator, and each was fed into the analog model as an external input. It was assumed that the core response did not affect the flow during coastdown.

16Preliminary Safety Analysis Report on the AARR, Approval Copy, Vol. II, Appendix C: March 31, 1966 (revised December 9, 1966). 
An effective flow-sensing lag (time constant) of $0.75 \mathrm{sec}$ was used in all cases considered in this study. This delay was assumed to be a maximum expected value for the total delay in the flow-detection channel between actual flowrate and the measured value used in $\phi / F$ safety channels. A time constant of $0.75 \mathrm{sec}$ is, however, expected to be far too conservative (high) for the AARR, whose $\phi / F$ safety channel will have a much shorter ef-

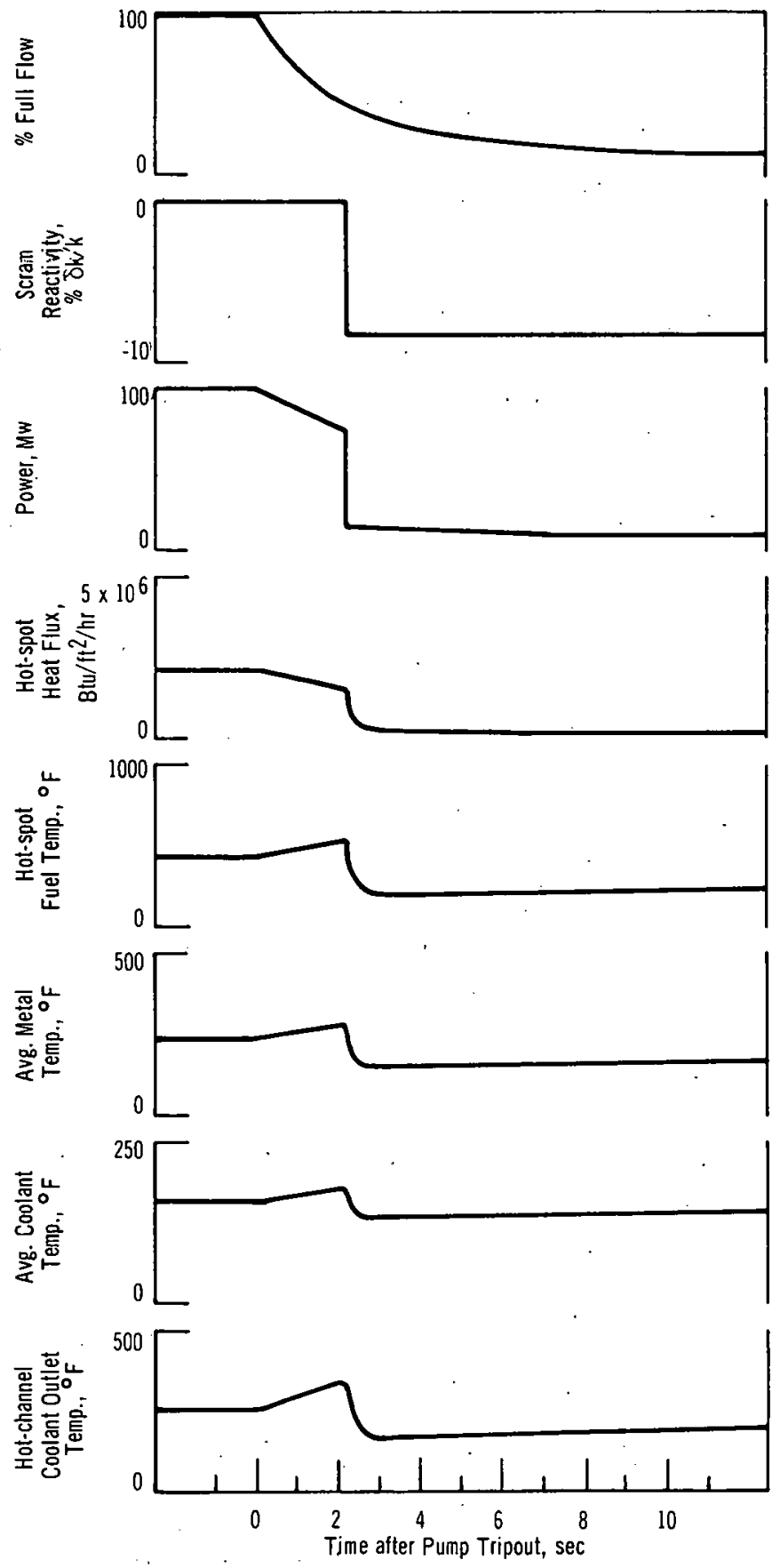

Fig. 20. Core Response to Flow Coastdown with One Pony Motor Operating after a $\phi / F$ Scram; Beginning-of life Core Parameters fective time delay; a preliminary investigation of this problem will be described in a future report.

The $\phi / F$ criterion for scram and the flow-sensing delay used in this study is that "scram" occurs for $\phi / F \geq 1.3$, where $\phi$ is normalized flux or power, $F=$ $\mathscr{L}^{-1}\left[\mathrm{~F}^{\prime}(\mathrm{s}) /(1+\tau \mathrm{s})\right]=$ measured nor malized flow, $F^{i}=$ actual flow, $\tau=750 \mathrm{msec}, \mathrm{s}=$ Laplace variable, and $\mathfrak{L}^{-1}=$ inverse Laplace Transform.

(ii) Calculated Results. The analog calculations made can be grouped according to the following effects: (a) effect of coastdown with no pony motor versus one pony motor, (b) effects of parameter values at beginning of life (B.L.) versus end of life (E.L.), where the parameters assumed to change are listed above, and (c) effect of reactor scram versus no scram. Thus a total of eight calculations were made, and for each the following eight variables were recorded graphically: (1) reactor flowrate in $\%,(2)$ scram reactivity insertion in $\% \Delta \mathrm{k} / \mathrm{k}$, (3) reactor power in $\mathrm{MW}$, (4) hot-spot heat flux in $\mathrm{Btu} / \mathrm{hr} / \mathrm{ft}^{2}$, (5) hot-spot fuel metal temperature in ${ }^{\circ} \mathrm{F},(6)$ average fuel metal temperature in ${ }^{\circ} \mathrm{F}$, (7) average coolant temperature in core in ${ }^{\circ} \mathrm{F}$, and (8) hot-channel coolant outlet temperature in ${ }^{\circ} \mathrm{F}$.

A typical set of response curves are depicted in Fig. 20. 
Table XXVI summarizes the major results obtained from the eight analog runs, in order of increasing severity of the thermal transient (maximum fuel temperature). It must be emphasized that this study was performed to analyze the coastdown response, both including and excluding $\phi / F$ safety channel protection but never "taking credit for" control-channel response. Thus, the analog model did not simulate the "Setback" and "Reverse (Fast)" control functions which will normally take place during this transient. "Setback" occurs for $\phi$ (DEMAND) $/ F>1.0$; consequently, power is reduced via the shim-regulating cylinder because flow then becomes the demand set point for the flux-control system. "Fast Reverse" occurs for $\phi / F \geq 1.1$, resulting in rapid reduction of power via rapid shim-safety plate insertion. These control functions are designed to preclude the need for reactor scram upon flow coastdown.

TABLE XXVI. AARR Response to Flow Coastdown ${ }^{a}$

\begin{tabular}{|c|c|c|c|c|c|c|c|c|c|c|}
\hline $\begin{array}{l}\text { Pony } \\
\text { Motor }\end{array}$ & $\begin{array}{l}\text { Core } \\
\text { Life }\end{array}$ & $\begin{array}{c}\text { Power } \\
\text { (MW } \\
\text { or \%) }\end{array}$ & $\begin{array}{c}\text { Flow } \\
F^{\prime} \\
(\%)\end{array}$ & $\begin{array}{l}\operatorname{Max} \\
\phi / F^{\prime}\end{array}$ & $\begin{array}{l}\mathrm{T}_{\mathrm{hs}} \\
\left({ }^{\circ} \mathrm{F}\right)\end{array}$ & $\begin{array}{c}\mathrm{T}_{\mathrm{C}} \\
\left({ }^{\circ} \mathrm{F}\right)\end{array}$ & $\begin{array}{c}\mathrm{T}_{\mathrm{s}} \\
\left({ }^{\circ} \mathrm{F}\right)\end{array}$ & $\begin{array}{c}t_{1} \\
(\mathrm{~s} \text { ec })\end{array}$ & $\begin{array}{c}t_{2} \\
(\mathrm{sec})\end{array}$ & $\begin{array}{c}t_{3} \\
(\mathrm{sec})\end{array}$ \\
\hline \multicolumn{11}{|l|}{ Scram } \\
\hline One & Begin & 76 & 44 & 1.73 & 535 & 347 & 520 & 0.8 & 1.2 & 2.2 \\
\hline None & Begin & 75.5 & 43.5 & 1.74 & 538 & 349 & 523 & 0.9 & 1.25 & 2.2 \\
\hline One & End & 89 & 51 & 1.74 & 735 & 343 & 511 & 0.75 & 1.0 & 1.75 \\
\hline None & End & 89 & 51 & 1.74 & 737 & 343 & 511 & 0.8 & 1.0 & 1.7 \\
\hline \multicolumn{11}{|c|}{ No Scram } \\
\hline One & Begin & 35 & 10 & 3.5 & 772 & 600 & 765 & 0.8 & 1.2 & - \\
\hline One & End & 46 & 10 & 4.6 & 1080 & 740 & 761 & 0.75 & 1.0 & - \\
\hline None & Begin & $(30)$ & (6) & $(5.0)$ & $(880)$ & $(690)$ & $(874)$ & 0.9 & 1.25 & - \\
\hline None & End & $(40)$ & (6) & $(6.7)$ & $(1220)$ & $(850)$ & $(872)$ & 0.8 & 1.0 & - \\
\hline
\end{tabular}

aThe power, flow, and temperature columns show values when maximum $\phi / F$ occurs. The values in parentheses were chosen arbitrarily at $t=20 \mathrm{sec}$.

Symbol definitions:

$T_{\text {hs }}=$ Hot-spot fuel (meat) temperature.

$\mathrm{T}_{\mathbf{c}}=$ Hot-channel coolant outlet temperature.

$T_{\mathbf{S}}=$ Surface (oxide-water interface) temperature (deduced from analog results via quasisteady-state analysis).

$t_{1}=$ Time at which actual $\phi / F$ exceeds 1.30 .

$t_{2}=$ Time at which hot-spot heat flux exceeds incipient boiling heat flux.

$\mathrm{t}_{3}=$ Time at which $\phi / \mathrm{F}$ scram occurred.

The flow-sensing log of $0.75 \mathrm{sec}$ is quite long compared with the calculated 50\%-flow time delay $(1.8 \mathrm{sec})$ and was found to be very important in this study. Although scram was initiated when $\phi / F$ measured 1.3, it was found that the actual $\phi / F$ exceeded 1.7.just prior to scram. Smaller values of measuring lag were not tried in this study but, of course, would greatly reduce the maximum actual $\phi / F$ during the transient. 
It was found that the corre-averaged coolant temperature did not reach boiling temperatures (remained $<300^{\circ} \mathrm{F}$ ) except for the two cases where no pony-motor coastdown was combined with no scram. However, the hot-spot surface (oxide-water interface) temperature exceeded the local boiling threshold for all cases primarily because of the long flowsensing delay. The hot-spot fuel (meat) temperature did not exceed $1100^{\circ} \mathrm{F}$ except for the two no pony motor-no scram cases. Table XXVI shows peak values of the pertinent variables for all the cases.

The initial thermal transient caused by coastdown is es sentially not affected by the absence of a pony motor. Later in the transient, however, temperatures reach very high values.

The primary effects of cycle time on core response to coastdown are (a) the $188^{\circ} \mathrm{F}$ (assumed) increase in fuel-to-coolant $\triangle \mathrm{T}$ at end of life due to scale formation and (b) lower reactivity feedback coefficients at the end of life. As a result, the end-of-life conditions appear to be more critical than for beginning of life.

Finally, the results show that safety action upon excessive $\phi / F$ values is absolutely essential for maintaining core integrity. The criterion for "excessive $\phi / F$ " is herein assumed as actual $\phi / F \geq 1.40$, corresponding approximately to Fig. 8.1.1 in the HFIR description report. ${ }^{17}$ Although the maximum safe value of $\phi / F$ is expected to increase both during the core cycle and with decreasing flow, the conclusions of this study assume that that value remains constant. The " included primarily to evaluate the effects of scram delayed by an arbitrary time interval. However, flow coastdown without a $\phi / F$ safety or control action is considered incredible in AARR.

(iii) Quasi-steady-state Analysis. Since the flow-coastdown transient is slow relative to the response of the core ${ }^{18}$ it had been assumed earlier that the thermal response of the core to coastdown could be considered a quasi-steady-state process. A comparison was thus made (for the first case in Table XXVI) between the actual analog output and steadystate calculations using instantaneous values of power and flow at various times throughout the transient. This comparison is given in Table XXVII, which shows that the thermal lags and heat-transport effects are indeed negligible for the coastdown transient. In Table XXVII, the hot-spot film coefficient is assumed to vary as $(\mathrm{Flow})^{0.5}$, and the quasi-steady-state analysis is made as follows:

$$
\frac{q^{\prime \prime} \text { H.S. }}{\left(q^{\prime \prime} \text { H.S. }_{0}\right)}=\frac{P}{P_{0}}
$$

17The High Flux Isotope Reactor (A Functional Description), Vol. I, ORNL-3572 (May 1964)。

18 The effective fuel-plate time constant and coolant core transit times are both less than $35 \mathrm{msec}$ at rated conditions. 


$$
\begin{aligned}
& \Delta \mathrm{T}_{\mathrm{H} . \mathrm{C} .}=136\left(\frac{\mathrm{P}}{\mathrm{P}_{0}}\right)\left(\frac{\mathrm{Q}_{0}}{\mathrm{Q}}\right) ; \\
& \Delta \mathrm{T}_{\mathrm{H} . \mathrm{S} .}=2 \mathrm{I}\left(\frac{\mathrm{P}}{\mathrm{P}_{0}}\right)+150 \frac{\left(\mathrm{P} / \mathrm{P}_{0}\right)}{\left(\mathrm{Q} / \mathrm{Q}_{0}\right)^{0.5}}
\end{aligned}
$$

where $P$ is power and $Q$ flow.

\begin{tabular}{|c|c|c|c|c|c|c|c|c|}
\hline \multirow[b]{2}{*}{$\begin{array}{l}\text { Time } \\
(\text { s e c) }\end{array}$} & \multirow[b]{2}{*}{$\begin{array}{l}\text { Flow } \\
(\%)\end{array}$} & \multirow[b]{2}{*}{$\begin{array}{c}\text { Power } \\
(\%)\end{array}$} & \multicolumn{3}{|c|}{ Análog Results } & \multicolumn{3}{|c|}{ Quasi-steady State } \\
\hline & & & $\begin{array}{c}\text { Bulk } \\
\Delta \mathrm{T}_{\mathrm{H} . \mathrm{C}} . \\
\left.{ }^{\circ} \mathrm{F}\right)\end{array}$ & $\begin{array}{c}\text { Plate to } \\
\text { Coolant } \\
\Delta \mathrm{T}_{\mathrm{H}} . \mathrm{S} . \\
\left({ }^{\circ} \mathrm{F}\right) .\end{array}$ & $\begin{array}{c}\mathrm{q}^{1} \mathrm{H} . \mathrm{S} . \\
\left(10^{6} \mathrm{Btu} /\right. \\
\left.\mathrm{ft}^{2} / \mathrm{hr}\right)\end{array}$ & $\begin{array}{c}\text { Bulk } \\
\Delta \mathrm{T}_{\mathrm{H} . \mathrm{C}} . \\
\left({ }^{\circ} \mathrm{F}\right) .\end{array}$ & $\begin{array}{c}\text { Plate to } \\
\text { Coolant } \\
\Delta \mathrm{T}_{\mathrm{H} . \mathrm{S} .} \\
\left({ }^{\circ} \mathrm{F}\right)\end{array}$ & $\begin{array}{l}\mathrm{q}^{\prime \prime} \mathrm{H} . \mathrm{S} . \\
\left(10^{6} \mathrm{Btu}\right. \\
\left.\mathrm{ft}^{2} / \mathrm{hr}\right)\end{array}$ \\
\hline 0.0 & 100 & 100 & 136 & 171 & 2.1 & 136 & 171 & 2.1 \\
\hline 0.25 & 91 & 98 & 144 & 175 & 2.0 & 146 & 174 & 2.05 \\
\hline 0.75 & 73 & 92 & 164 & 180 & 1.88 & 171 & 181 & 1.93 \\
\hline 1.25 & 60 & 85 & 189 & 182 & 1.75 & 193 & 184 & 1.79 \\
\hline 1.75 & 51 & 80 & 209 & 183 & 1.64 & 214 & 186 & 1.68 \\
\hline 2.15 & 44 & 76 & 226 & 188 & 1.57 & 235 & 189 & 1.60 \\
\hline 5.0 & 25 & 10 & 53 & 33 & 0.20 & 54 & 32 & 0.21 \\
\hline
\end{tabular}

TABLE XXVII. Comparison of Analog and Quasi-steady-state Calculations

(iv) Conclusions. In summary, the five essential conclusions of this study of core response to flow coastdown are:

1. Safety action following loss of flow to the reactor is essential from a reactor safeguards point of view; however, ORNL has demonstrated that Setback and Reverse actions on HFIR actually preclude the need for scram.

2. Higher values of actual $\phi / F$ are reached at the end of life than at the beginning of life; thus, although the $\phi / F$ threshold for local boiling tends to increase during the core cycle, the core may be more vulnerable to coastdown at the end of life.

3. Core response to coastdown with none or one pony motor is essentially identical for the "initial" transient; later, however, temperatures rise to unacceptably high values without pony motor $(s)$.

4. The value of the flow-sensing delay is apparently very important in preventing high_values of_actual $\phi$ /F_prior to scram.

5. The coastdown transient is sufficiently slow that the temperatures and heat fluxes can be computed as suming quasi-steady-state thermal behavior with reasonable accuracy; comparison of this calculation with analog results shows that the relative errors in bulk $\Delta \mathrm{T}$ and heat flux are no more than 5 and $3 \%$, respectively. 


\section{Component Development}

\section{a. Beam Tubes}

(i) Beam-tube Piston-ring Seal Test. A fixture (see Fig. 21) has been designed and fabricated for leakrate testing the piston seal rings in the prototype beam tubes. The fixture consists of a test vessel with a gasketed and bolted cover plate; within the vessel is a piston equipped with two circular seal rings that are retained within the grooves of the piston. The hooked-end seal rings are compressed when inserted into the vessel with the piston. The energy stored in the rings forces the seal rings to contact the inside diameter of the test vessel. The test vessel, 8.500-8.502 in. in inside diameter, was machined to an rms-16 surface finish and will correspond to the reactor-vessel beam-tube nozzle bore. The piston material is Type 304 stainless steel; the outside diameter, ring groove dimensions, and the surface finishes correspond to those of the prototype beam tube. The two commercially available hooked-end piston seal rings are designed to operate in demineralized water at $250^{\circ} \mathrm{F}$ and $875 \mathrm{psi}$, with a maximum $\Delta \mathrm{p}$ of $55 \mathrm{psi}$; the material is 17-4 AMS5643 heat-treated to condition H1025.

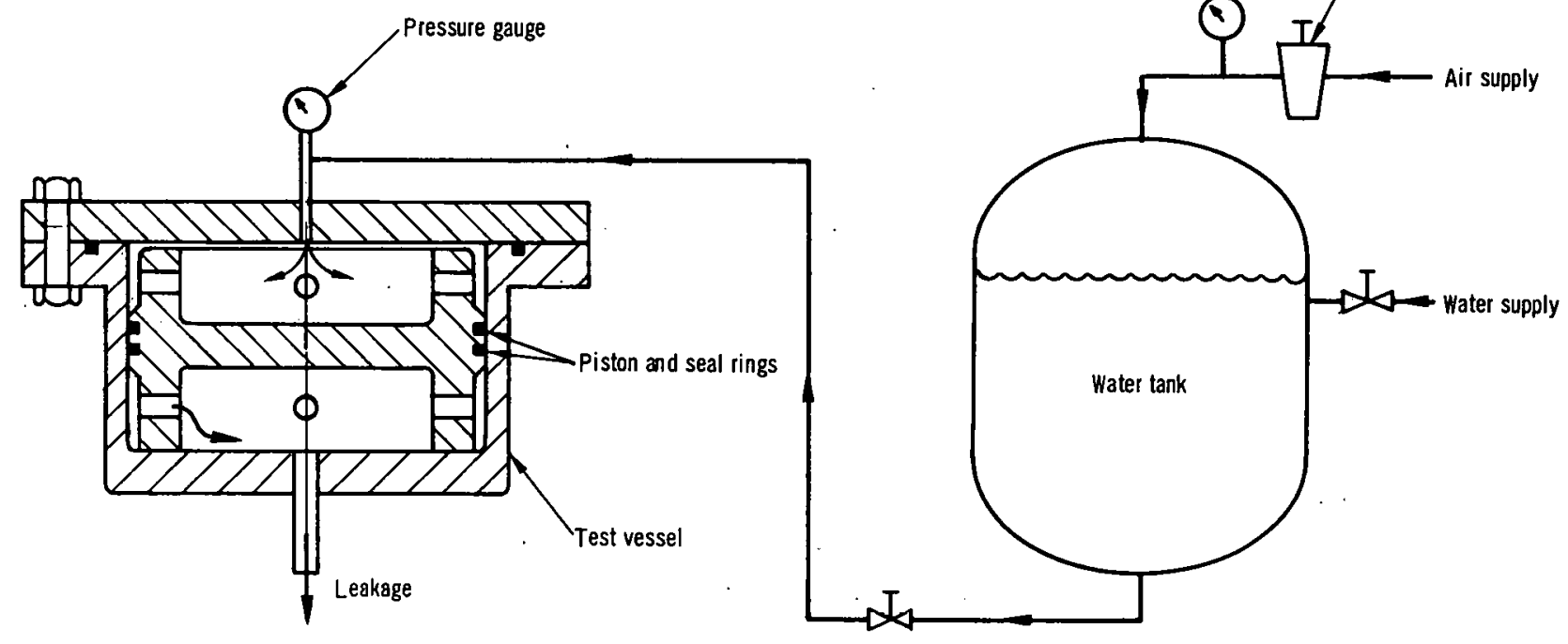

Fig. 21. Fixture for Testing Piston-ring Seals for Beam Tube

Water is supplied to the test vessel from a water tank pressurized with air to the desired pressure. Water that leaks past the seal rings was collected and weighed. The leakrate test indicated that the piston seal rings are acceptable for AARR beam-tube application.

(ii) Beam-tube Shield-plug Test Sleeve. The test sleeve described previously (see Progress Report for March 1967, ANL-7317, p. 94) was modified to demonstrate the method of mixing and pumping high-density grout into the test sleeve. The modifications included the addition of gasketed 
and bolted end flanges to the sleeve. The end flanges are fitted with pipe nozzles and valves to permit hose connections for pumping the grout into the sleeve cavity. A pipe nozzle with a valve is fitted to the top of the sleeve to permit venting and overflow of the grout during filling.

An appropriate mix consisting of ferrophosphorous sand (maximum particles passing No. 4 screen), cement, water and a shrinkagelimiting additive was prepared. The high-density grout was pumped into the cavity. After $72 \mathrm{hr}$ of curing time, the test sleeves were removed. Visual inspection revealed a very good casting as compared with a casting made by the hand-packing method. Radiographs made with a 40-Ci Ir ${ }^{192}$ source showed a void-free and uniformly dispersed aggregate throughout the concrete casting. The weight of the concrete casting was $3220 \mathrm{lb}$; average density was $\sim 225 \mathrm{lb} / \mathrm{ft}^{3}$. This test shows that the pumping method can be applied to fill the annulus in the AARR biological shield and beamtube adapter with high-density grout with good control of voids and density of the concrete.

\section{Core Development}

a. Steady-state Heat-transfer Experiments. The effects of channel spacing, flow, temperature of inlet water, pressure, and power on pressure differential along the channel, void distribution, and critical heat flux are being measured in electrically heated rectangular test sections that simulate the flat- or involute-plate geometry of the AARR core.

Single-channel tests were run at an exit pressure of $\sim 655$ psia and $135^{\circ} \mathrm{F}$ inlet with a nominal $0.040-$ in. test section. Channel spacing was measured under an internal pressure of $\sim 650$ psig, which confirmed a 0.040-in. channel (see Progress Reports for May 1966, ANL-7219, pp. 58-62, and December 1966, ANL-7286, pp. 58-64). Powers of $100 ; 125 ; 150$ and $175 \mathrm{~kW}$ were used.

The test results compared well with results calculated by the STDY-3 Code. An example is shown in Fig. 22 (the circles represent the calculated points; the triangles represent actual data). The flowrates for the inception of local boiling, as found by using the HFIR design approach (denoted by the arrow for the Bergles-Rohsenow correlation ${ }^{19}$ ) and as precicted by the STDY -3 Code, ${ }^{20}$ are also shown.

For the 100-, 125-, and 150-kW powers, the condition for flow instability-in parallel-multichannel-s $\odot$ ecu-r.s before critical heat flux.is.

\footnotetext{
19 Bergles, A. E., and Rohsenow, W. M., Trans. ASME J. Heat Transfer, Pp. 365-372 (Aug 1964). 20STDY -3, A Program for the Thermal Analysis of a Pressurized Water Nuclear Reactor during Steady-state Operation, WAPD-TM-213 (June 1960).
} 
reached. (The condition for flow instability in parallel multichannels corresponds to the flow at which the pressure drop is a minimum.) Operation with the single-channel test section at powers of 100,125 and $150 \mathrm{~kW}$ and at lower flows than that corresponding to the minimum in the pressure-drop curve was maintainable, and a critical-heat-flux condition was not noted. However, with $175-\mathrm{kW}$ power, a minimum in the pressure-drop versus flow curve was not attained. Also, while conducting the tests at this power, the test section experienced an actual burnout. Unfortunately, good data for the actual burnout conditions were not obtained.

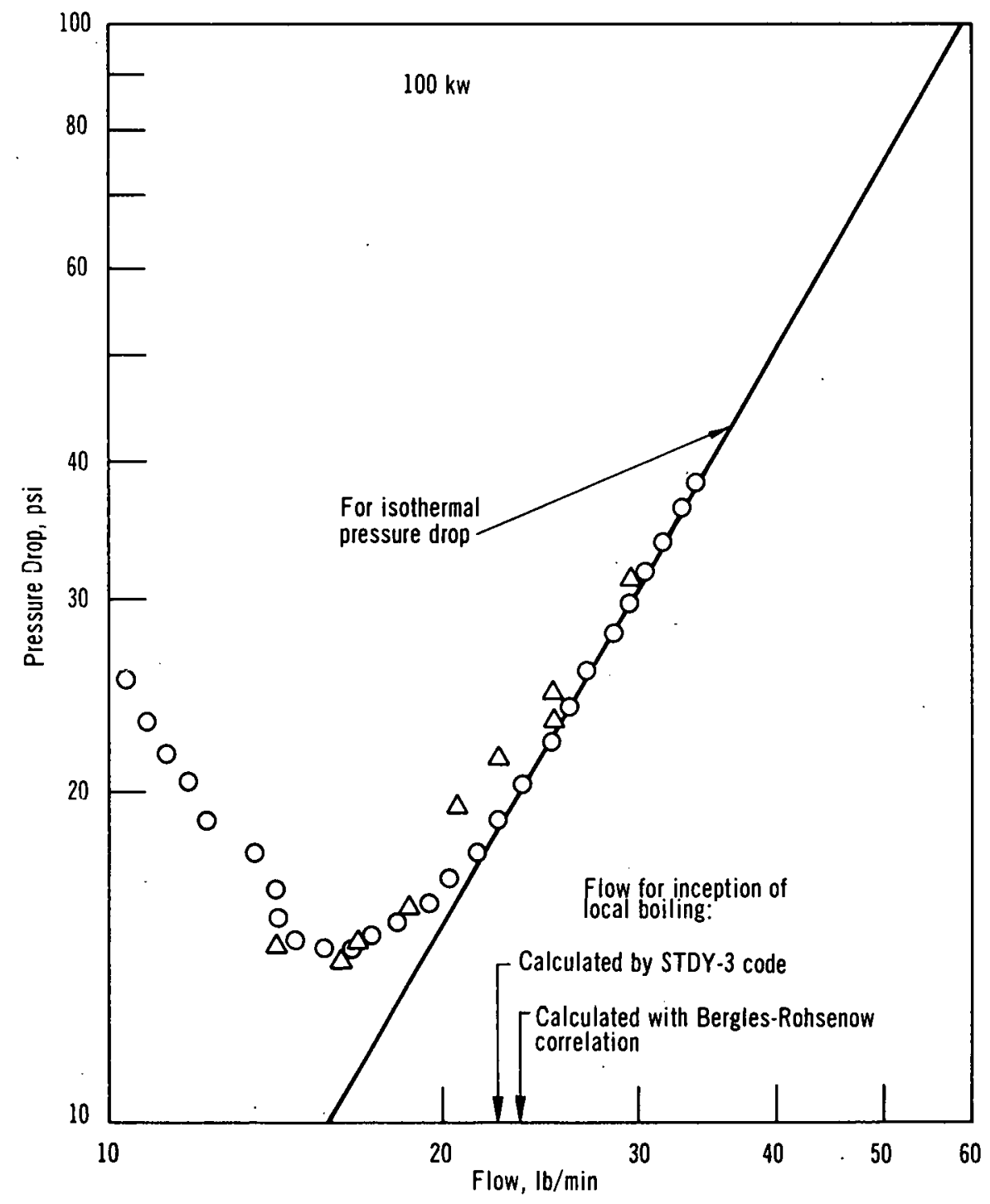

Fig. 22. Effect of Flow on Pressure Drop in 40-mil Channel Operating at $100 \mathrm{~kW}\left(1.391 \times 10^{6} \mathrm{Btu} / \mathrm{ft}^{2} / \mathrm{hr}\right)$

For parallel-multichannel systems, the minimum of the curve of pressure drop versus.flow is important for predicting the onset of flow instability. The design approach used for the HFIR core during normal operation is to maintain cooling conditions that prevent incipient nucleate 
boiling as predicted by the Bergles-Rohsenow correlation. Therefore, the experimental pressure-drop minima were compared with the flow for incipient nucleate boiling as given by this correlation. Table XXVIII shows: the results. The ratios of flows and pressure drops shown may be thought of as a form of safety factor, in that they indicate the ratio by which the flow or pressure drop at incipient nucleate boiling is greater than that for the onset of flow instability. Notice that the ratios of flows for incipient nucleate boiling and the minimum in the pressure-drop curve, $W_{\text {inb }} / W_{m p d}$, are fairly close to each other, ranging from 1.45. to 1.53 for the power range for 100 to $150-\mathrm{kW}$, where flow instability is a problem. It is interesting also to note that a ratio of 1.41 existed for the $175-\mathrm{kW}$ data obtained just previous to burnout, even though the flow-instability criterion does not apply. These values of the ratio of $\mathrm{W}_{\mathrm{inb}} / \mathrm{W}_{\mathrm{mpd}}$ are lower than the same ratios obtained with the 51 -mil test section, namely 1.84 to 1.99; however, compared with the ratios of 1.33 to 1.53 for the $30-\mathrm{mil}$ distorted test section, the 40-mil test section shows little difference. The same observation is noted with regard to the ratio of $\Delta \mathrm{P}_{\mathrm{inb}} / \Delta \mathrm{P}_{\mathrm{mpd}}$.

TABLE XXVIII. Compàrison of Incipient Nucleate Boiling Flow and Pressure Drop with the Flow and Pressure Drop Corresponding to the Minimum of the Curve of Pressure Drop versus Flow

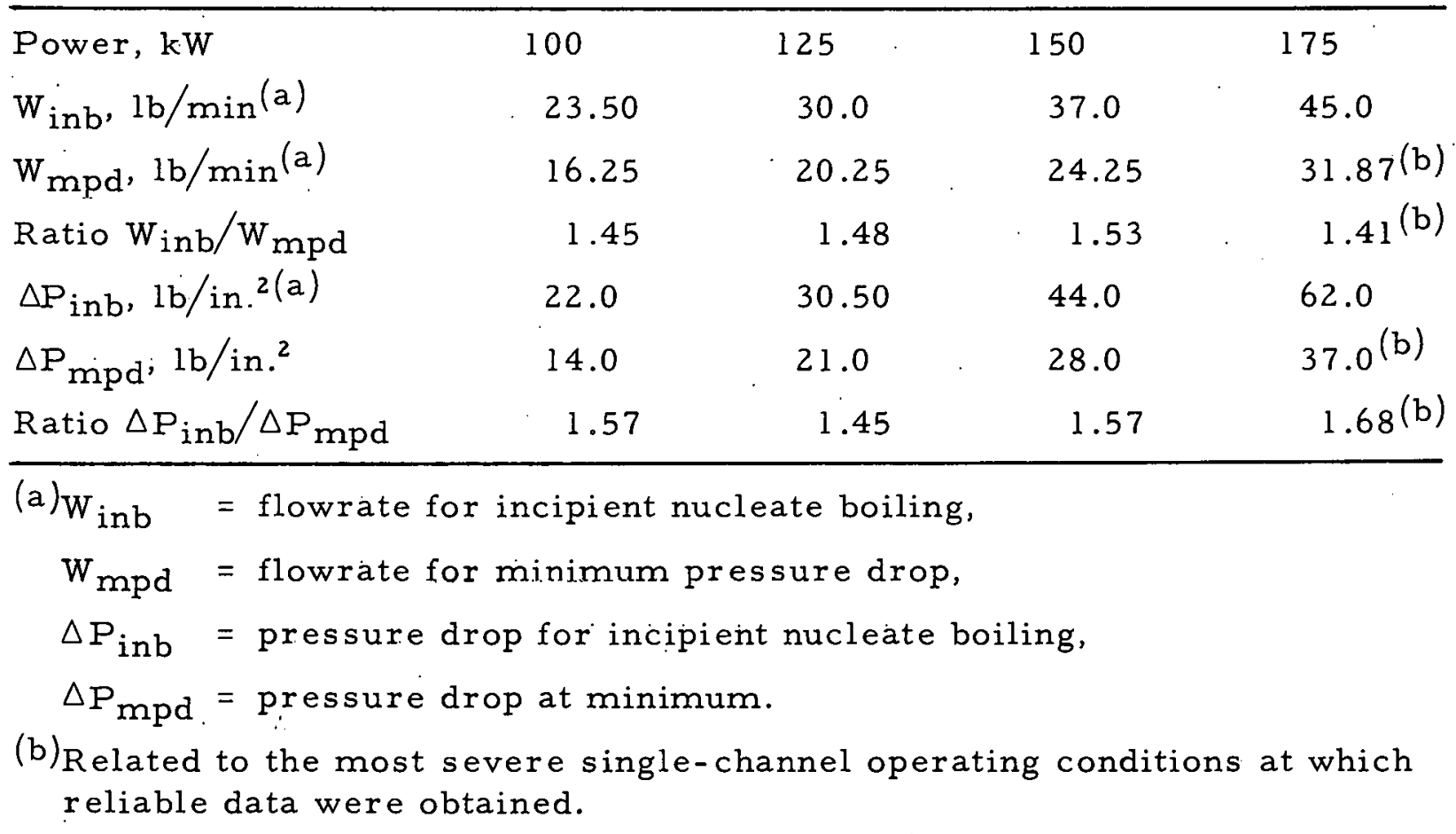

The relationship between flow instability and the ratio of the exit temperature rise above the inlet temperature to the saturation temperature rise above the inlet temperature for the minima of the pressure-drop versus flow curves was analyzed. Table XXIX gives the results. The values for the 
40-mil channel range from 0.84 to 0.94 and appear reasonable, bas ed on previous studies using the computer code STDY-3 and with the test results from 30 - and 50-mil test sections (see Progress Report for December 1966, ANL-7286, pp. 58-64).

TABLE XXIX. The Quantity $r$ Corresponding to the Minimum of the Curve of Pressure Drop versus Flow

$$
\left(r=\frac{\text { Exit temperature minus inlet temperature }}{\text { Saturation temperature minus inlet temperature }}\right)
$$

\begin{tabular}{crrrr}
\hline Power, kW: & 100 & 125 & 150 & 175 \\
r: & 0.940 & 0.943 & 0.945 & $0.839^{\mathrm{a}}$
\end{tabular}

a Related to the most severe single-channel operating conditions at which reliable data were obtained. 


\section{NUCLEAR SAFETY}

\section{A. Coolant Dynamics}

\section{Sodium Expulsion}

An experiment, in which it is planned to investigate the mechanism of coolant expulsion in a simulated reactor environment, includes measurement of the void distribution, expulsion velocities, pressure transients, and liquid superheats during coolant expulsion:

Pending delivery of the programmed electron-bombardment heater within the next several months, plans have been made for investigating related analytical problems, such as temperature profiles in sodium prior to boiling.

\section{Superheat}

To determine the amount of liquid superheat required to initiate nucleate boiling in sodium under various conditions simulating a reactor environment, the independent and combined effects of pressure, dissolved gas, heat flux, surface characteristics, and the pressure-temperature history of the system will be measured experimentally.

Installation of the thermal-radiation heater is continuing. This heater is expected to extend the previously attained range of heat flux significantly. Reduction of the superheat data also is continuing.

\section{Critical Flow}

Calculations indicate that critical flow may occur in the core of a sodium-cooled reactor during an accidental power surge. Critical flow could lead progressively to detrimental effects such as voidage of the coolant channel, shock phenomena, and pressure buildup.

To.investigate such occurrences, identical loops have been built for measuring sodium liquid-vapor and steam-water critical flowrates; measurements include critical pressure, critical flowrate, stagnation temperature and pressure, and axial temperature profile in the test sections. Critical-flow data for sodium have been. collected, including exit critical pressure ranging from 0.5 to $6^{\prime \prime}$ psia, flowrates up to $1200 \mathrm{lb} /$ $\mathrm{ft}^{2}$ /s.e.c. and stagnation temperatures up to $160.0^{\circ} \mathrm{F}$. Similar-data are being collected for steam-water mixtures. In Figs. 23 and 24 , sodium and water data for stagnation temperatures of 1380 and $154^{\circ} \mathrm{F}$, respectively, are compared. Large deviations from the Homogeneous Thermal Equilibrium Model (HEM) are demonstrated for water as well as sodium, the ratio $\mathrm{G}_{\text {exp }} / \mathrm{G}_{\mathrm{HEM}}$ being higher for the sodium data. 


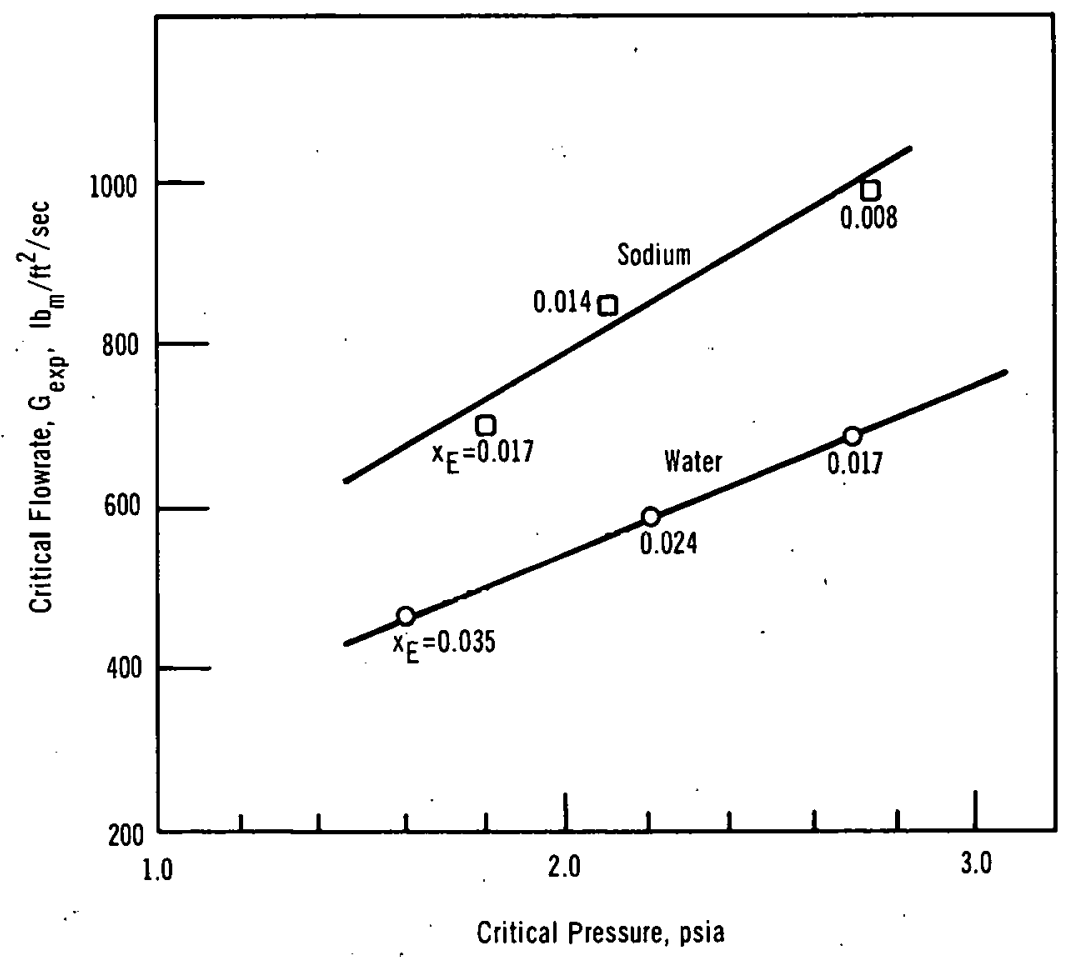

Fig. 23. Critical Flow for Sodium Liquid: Vapor and Water: Steam

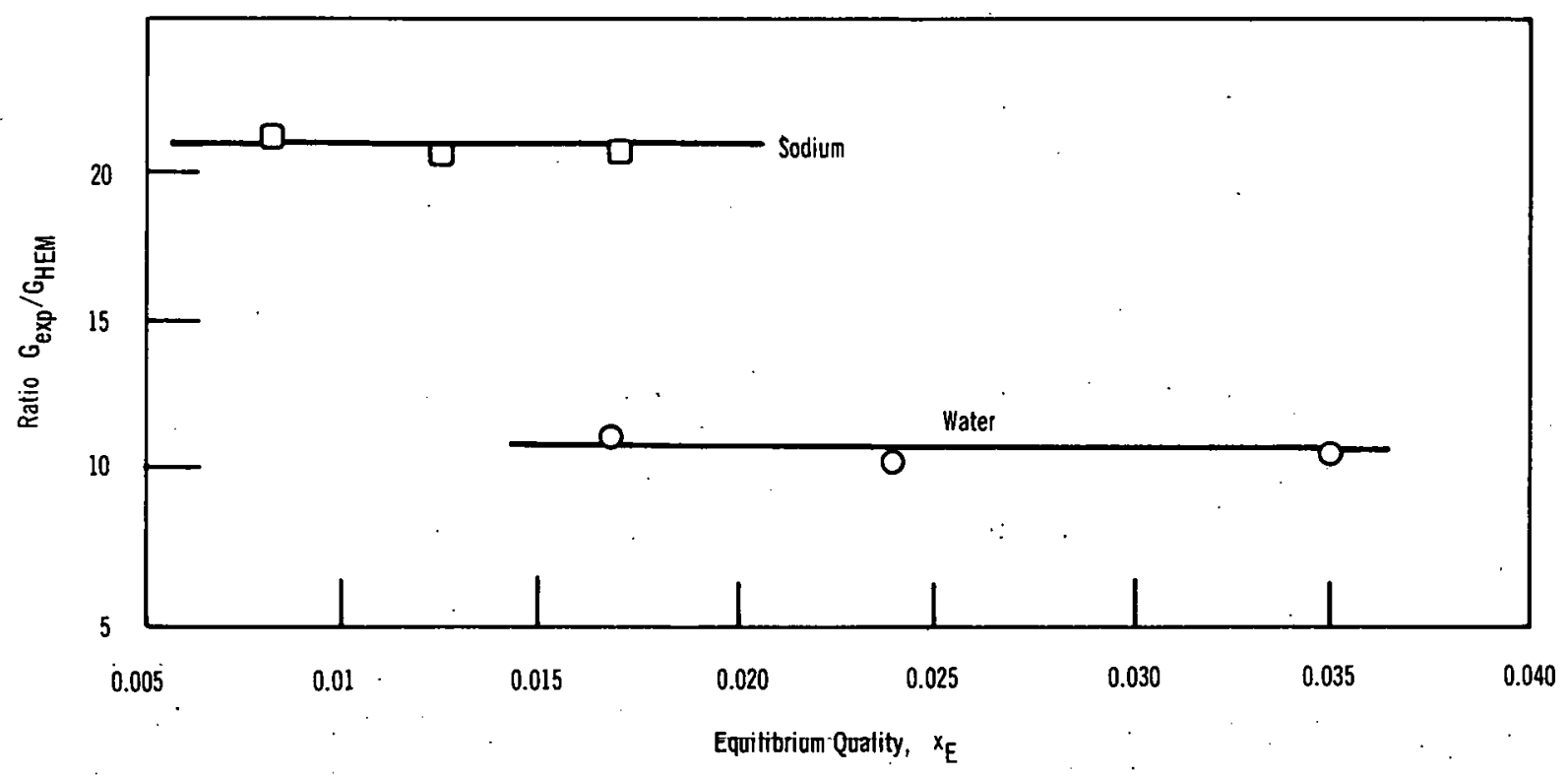

Fig. 24. Comparison of Measured $\left(G_{\text {exp }}\right)$ and Calculated $\left(G_{H E M}\right)$ Critical Flowrates for Sodium and Water

The larger deviation between calculated (HEM) and measured maximum expulsion rates for sodium is attributed primarily to much higher initial superheats required before flashing takes place than is required for water; because of much greater contents of dissolved gases, water experiences little or no superheat. The initial superheats for the sodium data in 
Figs. 23 and 24 range from $\sim 40$ to $60^{\circ} \mathrm{F}$. On the other hand, both sets of data experience large superheats in the two-phase region during the flow expansion upstream of the point of choking. For the water data in Figs. 23 and 24 , superheat ranges from 17 to $34^{\circ} \mathrm{F}$, whereas for the sodium data the range is from $\sim 45$ to $90^{\circ} \mathrm{F}$. Although the large two-phase superheats and correspondingly high expulsion rates obtained appear favorable in light of fast-reactor safety, they are, unfortunately, severely. detrimental to analytical treatments based on stable equilibrium conditions. Reduction and analysis of the data are continuing.

A new test section is being designed; it will have a constant-area section upstream and a slightly diverging section downstream of the point of choking. Axial temperature as well as pressure-gradient measurements will be attempted. The test section now being tested has an abruptexpansion section downstream of the point of choking and is not instrumented for measurements of axial pressure gradient. The test section being designed should yield more accurate measurements of critical pressure, of initial superheat sustained before forced-circulation boiling takes place, and of the superheat in the two-phase region.

\section{Electron-bombardment Heater Tests}

The operation of various electron-bombardment heaters (EBH), which will simulate in-pile experiments pertaining to reactor safety, is being examined in a large evacuated vessel. Both single-pin heaters and multi-pin heaters will be built and tested.

Fabrication of the first EBH test section is $\sim 50 \%$ complete. Three banks of powerstats are being installed in the high-voltage power supply to enable positive control over the EBH power ranging up to $200 \mathrm{~kW}$. Also, several minor modifications to the high-voltage power supply are being made to improve the utility of the EBH test experiments.

\section{Convective Instability}

The experimental apparatus is in the final stages of construction after minor delays caused by slow delivery of ordered items. All mechanical parts have been operated independently; they appear to function well. Electrical-power connections to supply and control $300 \mathrm{~A}$ at $480 \mathrm{~V}$ are essentially finished. An interlock system is being designed so that there can be no error in startup of the unit.

Analytical solutions were attempted in a few runs using the third approximation. These met with little success. Apparently, an essential singularity may exist in the higher-order solutions, which could make the solutions impossible to acquire. 


\section{Thermophysical Properties of Sodium}

The literature on sodium thermophysical properties has been evaluated to form a basis for recommending "best values" of these properties. Comparisons of safety studies of sodium-cooled fast breeder reactors will be more meaningful if the various groups doing such studies use standardized data. Recent related experimental work serves as the impetus for this evaluation. The sodium thermophysical property survey and report (see Progress Report for February 1967, ANL-7308, p. 84) has been drafted and will be reviewed before being published as report ANL-7323. The report covers the liquid density, vapor pressure, thermodynamic and P-V-T properties, transport properties, electrical resistivity, and surface tension.

\section{B. Fuel Meltdown Studies with TREAT}

1. Reactivity Measurements for Large Loop and Test-section Mockup

a. Physics Measurements on Large TREAT Loop Test-section Mockup. A detailed mockup was prepared of the large TREAT sodium-loop test section for reactor physics measurements at the TREAT reactor. The mockup and test clusters of sample pins and of sample blanket sections were irradiated in order to:

(i) measure the reactivity worth of the loop test section loaded inside the reactor loop test hole liner, with full reactor viewing slots;

(ii) measure the reactivity worth of two reference sample clusters, including sample blanket pins;

(iii) check the changes in control-rod worth;

(iv) measure the power distributions through the reference clusters;

(v) obtain experimental ratios of sample power to reactor power for the reference exposed clusters in the TREAT reactor with this full slot and large core loading to accommodate the loop.

The first cluster consisted of $37 \mathrm{EBR}$-II pins, all enriched to $8 \%$, surrounded by 54 steel dummy pins. The second cluster contains pins of graded enrichments to check compensation of cluster power depression by varying the enrichments over the cluster. The central pin was enriched to $7 \%$ and was surrounded by three concentric rings of a) six pins enriched to $6 \%$, b) twelve pins enriched to $4 \%$, and c) 72 steel dummy pins, to complete the standard 91-pin EBR-II subassembly. Fully enriched uranium foils were attached to the cladding surfaces of pins in the cluster. In some 
cases, three foils were attached around the cladding periphery at a given axial position in order to measure the azimuthal power variations. Both. sample clusters have been returned to Illinois and have been disassembled. Foils and selected segments of fuel alloy have been submitted for radiochemical analyses.

b. Reactivity Measurements on Large Loop Assembly. The reactivity change resulting from the removal of four full and two slotted elements and the addition of the zirconium liner was measured and found to be $-2 \% \Delta \mathrm{k}$. The change of reactivity in the case where all six of the removed fuel elements are full elements is estimated to be about $-3 \% \Delta \mathrm{k}$. The addition of Schedule 40 stainless steel pipes of 4 - and 3 -in. dia inside the zirconium liner (as simulation of the actual steel test section components) had been measured earlier ${ }^{21}$ to result in $\sim 2.7$ and $0.6 \% \Delta \mathrm{k}$ loss of reactivity, respectively. In the experiments performed during the report period, the addition of the actual test section and a 37-pin cluster (inside the 3 -in. pipe) produced a $3 \%$ loss of reactivity.

By comparison with the previously mentioned experiment, one could deduce that the 37 -pin cluster has a worth of about $+0.3 \% \Delta \mathrm{k}$. Direct measurement of the worth of the 37 -pin cluster yielded $+0.17 \% \Delta \mathrm{k}$.

The calculations performed previously predicted a $7 \% \Delta \mathrm{k}$ los upon the addition of the test section compared to the measured value of $6 \% \Delta \mathrm{k}:$

i. Substitution of zirconium liner for six TREAT elements

$$
\begin{aligned}
& -2 \% \\
& -1 \% \\
& -3 \% \\
& \hline-6 \%
\end{aligned}
$$

ii. Correction for all elements being full

There are some differences between the calculational model and the physical arrangement of TREAT during the experiment.

(1) The calculations assumed the TREAT was fully loaded (361 elements), whereas the experiment required 290 elements. If a smaller core were used in the calculations, the predicted value of the reactivity loss would be greater.

(2) The calculational model did not include the slotted fuel element present.

$21_{\text {Madell, J. T., Physics Analysis of TREAT with an EBR-II Subassembly, in Reactor Physics Division }}$ Annual Report: July 1, 1965 to June 30, 1965, ANL-7110, pp. 154-157. 
The calculated values of the reactivity changes would be less in a model which included the slotted elements.

The experiment measured that the control-rod worth for the critical TREAT reactor with the test section is about the same as for the critical TREAT reactor without the test sections. The calculations indicated that the control rods in a fully loaded TREAT are worth about $7 \% \Delta k$ more with the test section than without it. Experiment and calculations are not in disagreement but rather are considering two different situations. Insertion of the test section increases the required size of the core and also shifts the flux so the control rods are in a more important region. These two factors cancel themselves. The overall reactivity worth of a certain amount of material (control rod) decreases as the size of the core increases, while an increase in the importance in the region of the material will increase its reactivity worth. The measurements show that addition of the test section does not decrease the shutdown capacity of the reactor control rods below that of the reference, solid core loading.

2. Unbonded EBR - II Pin in Flowing Sodium

An argon-bonded EBR-II pin was exposed in flowing sodium in a Mark-I integral sodium loop to a TREAT transient. The experiment was planned to provide information for use in assessing the results of a possible cladding failure of a pin in EBR-II (see Progress Report for January 1967, ANL-7302, pp. 92-93). The loop was returned to the Illinois site for study of the sample. Calculations of the transient temperature made, assuming intact geometry, with the ARGUS code indicated that complete sample melting took place. However, there are large uncertainties in the heat transfer across the gas gap from fuel to cladding, the timing and speed of hot fuel slumping against the cladding, and the three-dimensional transient thermal stresses inside the cladding. All of these uncertainties can affect the severity of the transient, and experimental data are needed.

3. Power Supply for High-temperature Furnace Operation

A $300-\mathrm{kW}$ silicon diode, saturable-reactor-controlled, power supply has been delivered and installed in the hot laboratory building D301. The power supply will be used with a high-temperature furnace to provide data for the equation-of-state studies being performed as a part of the Fast Reactor Safety Program.

The supply has been tested successfully at D301 under a dummy load at levels up to $9000 \mathrm{~A}$ at $28 \mathrm{~V}$. Design maximum is $10,000 \mathrm{~A}$ at $30 \mathrm{~V}$. 
4. Glovebox for Low-level Beta-Gamma TREAT Samples Containing Plutonium

Facilities are necessary to handle plutonium-bearing TREAT specimens having low levels of beta-gamma activity. Specifications have been established for a glovebox to be installed in Building 301 which will accommodate the capsules, loops, and autoclaves used in the TREAT meltdown programs. Part of the partition between rooms Al06 and All4 is to be removed, permitting the space in both rooms to be used for the handling operations. In addition, cave-manipulator repair and a high-temperature furnace (see Sect. V.B.4) will share the area.

The glovebox will be of a modular design. It will be two modules high and three modules long, in order to accommodate test-section components of the loop and permit work to be performed on two experiments at the same time. The glovebox will have an auxiliary loading hood which provides space for loops or capsules while they are attached to the glovebox. Loops and capsules will be fastened to the glovebox using the splitflange technique to minimize the possibility of alpha contamination outside the glovebox; the auxiliary hood provides a backup to restrict spread of contamination and to permit a cleanup of any loop or capsule contamination occurring during glovebox operations. In addition, there will be a vacuum transfer. lock large enough to admit fuel samples. The high-pressure autoclaves of the violent meltdown experimental program in TREAT can also be loaded into the glovebox through the vacuum lock. A system for purification of recirculating inert gas will be used to supply and maintain an inert cover gas inside the glovebox. The auxiliary hood will be attached to the existing radioactive exhaust system serving room A 106 . However, the new installation will require an expansion of the capability of the exhaust system.

The glovebox installation is to accommodate samples which have only the relatively low beta-gamma activity resulting from TREAT irradiations. Alpha-containment caves for Fast Reactor Safety experimentation on specimens preirradiated in a steady-state reactor are being designed also.

\section{TREAT Operations}

An unbonded, $6 \%$ enriched EBR-II-type fuel pin contained in a package sodium loop was subjected to a flat-top-type transient designed to s-imulate-the power-dens-ity-in an-EBR- I-fuel-pin during normal-EBR-IIoperation. The reactor was shut down after $7 \mathrm{sec}$ when the power level exceeded the maximum value established for the experiment. Fast-neutronhodoscope data obtained following the transient indicate that gross failure did not occur during the transient. Small, localized cladding failures might 
not be detected by the hodoscope. The sample was returned to Argonne, Illinois, for examination. The fast-neutron hodoscope and associated new digital readout equipment were operated during this test, and the film has been sent to Argonne, Illinois, for analysis.

Two samples of prototype Fast Ceramic Reactor-type fuel (C-4-D and $\mathrm{C}-4-\mathrm{A}$ ) were ir radiated for the General Electric Company. The energy released during the transient on sample C-4-D may not have caused fuel melting, and it will be stored at TREAT until experimental data are compared with computer calculations and a decision is made on whether to subject this sample to another transient or return it for examination. Sample C-4-A will be subjected to another transient after data from the calibration transient are analyzed and specifications for the next transient are received from the General Electric Company.

A 37 -pin and a 19-pin cluster of EBR-II-type fuel elements were irradiated under steady-state conditions in a mockup of the test section of the large TREAT sodium loop. Radiochemical analysis of these pins and attached foils will be used to determine the relationship between reactor energy release and pin energy release. These data will be used to specify the reactor energy release required to obtain the desired test conditions during future transient tests using the large loop.

The cold trap and plugging metal systems for the large TREAT sodium loop were operated until the plugging temperature was reduced to less than $110^{\circ} \mathrm{C}$.

Investigation of the bolt failures in the safety head flange (see Progress Report for March 1967, ANL-7317, pp. 109-110) is continuing. Testing of the loop at design temperature is being delayed pending completion and action necessary to prevent similar bolt failures in the future.

D. Chemical and Associated Energy Problems (Thermal)

1. Laboratory Studies with Zircaloy-2-clad, $\mathrm{UO}_{2}$-core Fuel Rods Simulating the Conditions of a Loss-of-coolant Accident

Experiments have been continued to simulate the environment of the fuel in a water-cooled power reactor following a loss-of-coolant accident. In such a situation, the fuel would be subjected to a slowly rising temperature (compared to that of a transient) because of heating due to fission product decay and the exothermic cladding-steam reaction.

The experimental simulations of the metal-water reaction and meltdown conditions that will exist in a loss-of-coolant type of reactor accident are being performed by the following methods: 
(1) Fuel-meltdown Experiments. These simulate the chemical and fission-product-decay heating conditions in a reactor core upon loss of the primary coolant.

(2) Emergency-coolant-spray Experiments. These simulate the conditions in a reactor core when a drop in the primary-coolant-water pressure due to a loss of coolant activates a secondary-coolant spray.

a. Fuel-meltdown Experiments by an Induction-heating Method. Key unknowns in the analys is of the loss-of-coolant accident for power reactors which use $\mathrm{Zircaloy-clad,} \mathrm{UO}_{2}$-core fuel rods are the effective failure temperature and the mode of failure of the fuel rods. Failure models range from melting and dripping of Zircaloy at $1850^{\circ} \mathrm{C}$ (melting point of Zircaloy) to the total holdup of the $\mathrm{UO}_{2}$ by a shell of oxidized zirconium until temperatures reached 2600 to $2800^{\circ} \mathrm{C}$, where the oxidized cladding would be expected to melt. Uncertainty centers about the ability of partly oxidized cladding to maintain integrity at temperatures above the melting point of unoxidized cladding. Studies in the high-pressure furnace of the behavior of fuel rods under conditions simulating a lossof-coolant accident were limited to maximum furnace temperatures of $1600^{\circ} \mathrm{C}$ (see Progress Reports for July 1965, ANL-7082, p. 67, and May 1966, ANL-7219, p. 86). Thus, it was not possible in these experiments to effect melting of the Zircaloy cladding because of the temperature limitation of the furnace. Experiments were performed, therefore, using induction heating to achieve temperatures $>2000^{\circ} \mathrm{C}$ in order to observe some of the features of the failure and collapse of Zircaloy-2-clad, $\mathrm{UO}_{2}$-core fuel rods. Results utilizing single rods showed that there was no tendency for the Zircaloy to melt and drip from the fuel rod upon reaching a maximum temperature of $2140^{\circ} \mathrm{C}$. However, because a true simulation of the conditions expected during a loss-of-coolant accident requires a large number of fuel rods to achieve a realistic thermal environment for each rod, a four-rod experiment was performed.

Figure 25 shows the arrangement of the four simulated fuel rods made up of tubes (27-mil wall thickness) of Zircaloy-2 cladding filled with $\mathrm{UO}_{2}$ pellets. The rods, enclosed in a $1 \frac{9}{16}-\mathrm{in}$. quartz-tube steam channel, were placed with 0.6-in. center-to-center spacing in a square lattice by means of Teflon end-plugs. An induction coil, 3 in. long, surrounded the quartz tube near the center. Two tungsten-rhenium thermocouples (placed in channels between the inner edge of the Zircaloy cladding and the outer edge of the $\mathrm{UO}_{2}$ pellets) were used to measure the temperature of the sample; one thermocouple was positioned facing toward the center of the bundle, while the other was positioned facing toward the bundle perimeter. The input steam flowrate was established and maintained at $4 \mathrm{~g} / \mathrm{min}$ ( $1 \mathrm{~g} / \mathrm{min} / \mathrm{rod})$. 


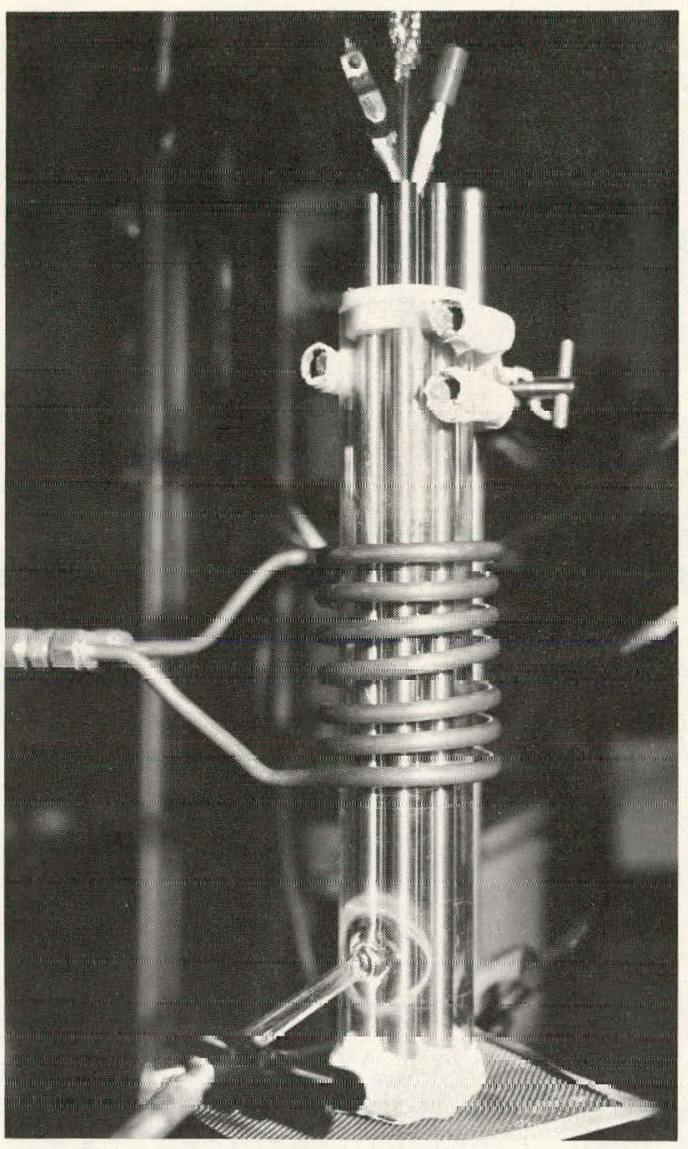

Fig. 25. Fuel-meltdown Assembly using Four Zircaloy-2-clad, $\mathrm{UO}_{2}$-core Simulated Fuel Rods
Figure 26 shows the sample temperature peaking after a.n 80-sec. heating period; shortly thereafter the thermocouple facing the center of the bundle indicatcd a sharp rise to $2950^{\circ} \mathrm{C}$. This sharp rise in temperature may have been caused by molten $\mathrm{UO}_{2}$ contacting the thermocouple and then falling away. Color films taken of the experiment confirm the uneven temperature distribution regislered by the thermocouples. The films show that hot zones occurred in areas adjacent to another rod, i.e., there was a large temperature gradient from the inner side of the rods to the outer side (the inner thermocouple was located in one of these hot zones).

Examination of the residue revealed extensive fragmentation, cladding rupture (in the areas adjacent to another rod), and evidence of molten $\mathrm{UO}_{2}$. Visual ulservaliun indicated that fragmentation occurred after the experiment had been terminated. X-ray diffraction examination of a 1/4-in.-dia droplet from one of the ruptured areas revealed a facecentered-cubic phase with lattice param-
$\AA$; $\left.\mathrm{ZrO}_{2}, 5.10 \AA\right)$, thus indicating a solid eters of 5.28 to $5.31 \AA\left(\mathrm{UO}_{2}, 5.470 \AA ; \mathrm{ZrO}_{2}, 5.10 \AA\right)$, thus indicating a solid
solution between $\mathrm{ZrO}_{2}$ and $\mathrm{UO}_{2}$. Electron-microprobe analysis of a similar particle showed the presence of mixed uranium-zirconium oxides which varied from $34 \mathrm{w} / \mathrm{o}$ uranium and $33 \mathrm{w} / \mathrm{o}$ zirconium to $24 \mathrm{w} / \mathrm{o}$ uranium and $43 \mathrm{w} / \mathrm{o}$ zirconium.

The temperature gradient observed between the inner and outer edges of each rod, and the subsequent longitudinal rupture of the cladding along the inner walls of the 4-rod bundle, indicate the need for additional experiments utilizing more rods per bundle: a center rod with at least one, and preferably two, outer rows of rods.

b. Emergency-coolant-sprayExperiments. In the event of a loss-of-coolant accident, one design of a water-cooled

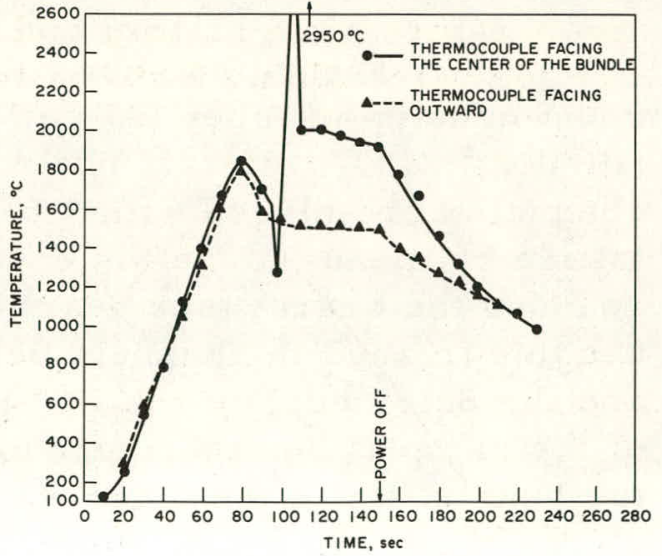

Fig. 26. Thermocouple Records of Fuel Meltdown by Induction Heating (Four Zircaloy-2-clad, $\mathrm{UO}_{2}$-core simulated fuel rods) 
reactor provides for activation of emergency-coolant spray by a drop in the primary-coolant-water pressure (below, approximately $150 \mathrm{psi}$ ). The question to be answered is: Will the hot fuel rods be effectively quenched and maintain their integrity when the emergency-coolant spray is activated?

In laboratory simulation of these conditions, single Zircaloy-2clad, $\mathrm{UO}_{2}$-core simulated fuel rods (as described above in Sect. V.B.1.a), enclosed in a quartz-tube steam channel, are being used. Two thermocouples are employed to measure sample temperature, one placed in a channel between the $\mathrm{UO}_{2}$ and the $\mathrm{Zircaloy}$, and the other spot welded to the outside of the cladding. An input steam flow of $1 \mathrm{~g} / \mathrm{min}$ is used to simulate a loss-of-coolant condition. The sample is inductively heated to a temperature above the melting point of $\mathrm{Zircaloy}-2$ (approximately $1850^{\circ} \mathrm{C}$ ), at which time water is sprayed into the top of the chamber at a rate of $190 \mathrm{~g} / \mathrm{min}$ [corresponding to $0.05 \mathrm{gal} /(\mathrm{min})$ (rod) for a reactor core]. Inductive heating is continued through the spray-cooling period.

In experiment $1 Z-4$, the fuel rod was successfully heated (at $\sim 23^{\circ} \mathrm{C} / \mathrm{sec}$ ) above the melting point of Zircaloy -2 and water was sprayed on the hot rod. The rod cooled from a maximum temperature of 2045 to $1380^{\circ} \mathrm{C}$ during the $30-$ sec spray period. Figure 27 illustrates the sharp drop in rod temperature during the spray period, and the subsequent increase in temperature after the spray was discontinued. Crumbling of the fuel rod after cooldown was noted in this experiment. Figure 28 shows the heating and cooling curves of two other experiments designed to simulate nearly total cooldown. In experiment $1 \mathrm{Z}-5$, a fuel rod simulating a reactor core at a temperature below the melting point of Zircaloy-2, cooled from 1750 to $110^{\circ} \mathrm{C}$ in $185 \mathrm{sec}$. In experiment $1 \mathrm{Z}-6$, a fuel rod simulating a

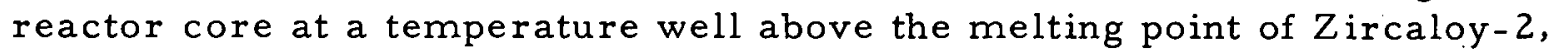
cooled from $\sim 2820$ to $95^{\circ} \mathrm{C}$ in $180 \mathrm{sec}$. The rods remained intact throughout the experiments but broke during dismantling of the cell. In these simulation experiments, the degree of fragmentation does not necessarily depend upon the maximum temperature to which the fuel rod is exposed; the temperature-time history and embrittlement caused by cladding oxidation are the determining factors (the two factors, of course, are not independent).

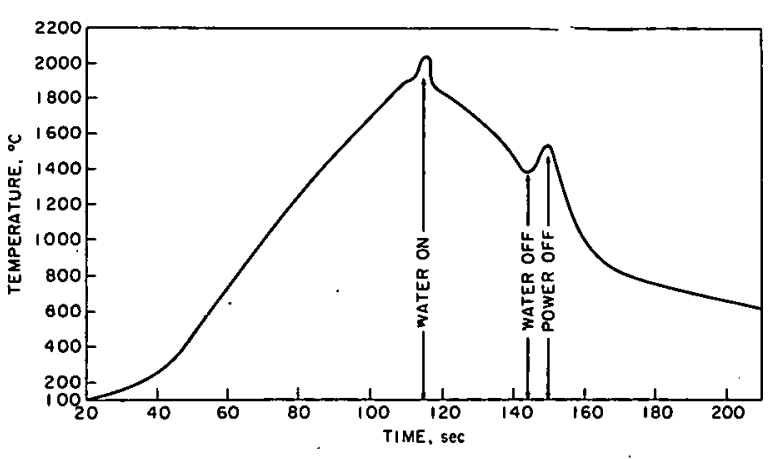

Fig. 27. Preliminary Emergency -coolanit-spray Experiment with a Zircaloy-2-clad, $\mathrm{UO}_{2}$-core Simulated Fuel Rod. Input Water Spray: $190 \mathrm{~g} / \mathrm{min}$.

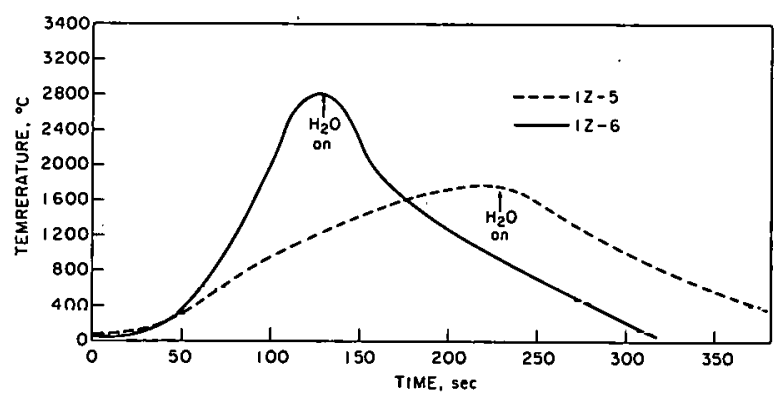

Fig. 28. Emergency-coolant-spray Experiments with Zircaloy-2-clad, $\mathrm{UO}_{2}$-core Simulated Fuel Rods Undergoing Nearly Total Cooldown. Coolant Spray Rate: $190 \mathrm{~g} / \mathrm{min}$. 
In noting the effects of an emergency-coolant-spray simulation, no attempts have been made to correlate heating and cooling rates to an actual reactor core; rather, the attempt has been only to demonstrate the feasibility of cooling a partially molten $\mathrm{Zircaloy-2-clad,} \mathrm{UO}_{2}$-core fuel rod (undergoing heating) by means of a water spray. Factors such as an insufficient number of rods in the simulation, and changing inductive coupling (as the cladding oxidizes) between the induction coil and the fuel rod, make a direct correlation of the efficiency of an emergency core-cooling system to an actual reactor core impossible.

\section{E. Safeguard Ṫechnology--Containment}

1. Primary Containment by Energy Absorption for Water Reactors

'To determine the applicability of this containment concept to water reactors, the possible effects of a hypothetical hydrogen-air-steam explosion in the primary cavity were studied. The term "explosion" covers combustion processes and therefore can be misleading when studying reactor accidents. To clarify the pertinent reactions, Moore and Gilbey ${ }^{22}$ define the processes as:

(a) Explosion--a combustion process controlled by chemical reaction rate and mixing processes; it generates pressure waves.

(b) Detonation--an advancing shock wave in which exothermic chemical changes take place in such a manner as to make the shock wave self-propagating.

To set off a combustion process, an ignition source is needed. This is possible through self-ignition of the gases or due to external sources of ignition. All studies on spontaneous ignition of hydrogen-air-steam mixtures show that such an occurrence is most unlikely; for external sources of ignition, energies of the order of millijoules are required for an explosion in hydrogen-air-steam mixtures, whereas the initiation level for detonation is $10^{4} \mathrm{~J}$ or more. Hence, generation of detonation waves is considered to be a most unlikely accident. A credible accident is an explosion from a spark source.

Calculations for such an accident show that the pressure wave generated will be less than 500 psi under the most optimum conditions. Thus, since pressures of this type present no damage potential to the primary containment, a hydrogen explosion would not invalidate the feasibility

22 Moore, J. G. and Gilbey, R. V., A Review of the Problems Arising from the Combustion of Hydrogen in a Water Reactor Containment, AHSB-S-R-101, United Kingdom Energy Authority, Authority Health and Safety Branch, 1966. 
of the concept. The inertial aspects of the primary-containment concept provide sufficient safety even against a hypothetical detonation. The response of the primary containment to such a loading has been treated in detail. ${ }^{23}$

\section{F. Plutonium Volatility Safety}

1. Chemistry of Tellurium Fluorides

Studies of the reactions of volatile tellurium fluorides are under way to determine the conditions under which tellurium is fixed on solid materials and to investigate the kinetics of the reaction. A series of nine experiments. has been completed to determine the effects of process variables on the sorption of $\mathrm{TeF}_{6}$ on activated alumina in a flow system. In the course of this study, an isotopic dilution technique employing $\mathrm{Te}^{125 \mathrm{~m}}$ tracer was developed which allowed direct measurement of the decontamination factor obtained across the bed of activated alumina. The process variables studied were: temperature of activated alumina, 25 and $100^{\circ} \mathrm{C}$; bed height, 1 and 2 in.; velocity of gas stream through. the activated alumina bed, 20 and $40 \mathrm{ft} / \mathrm{min}$; and concentration of $\mathrm{TeF}_{6}$ in the gas stream, 250 and $500 \mathrm{ppm}$. The results indicated that only the bed height had a significant effect on the tellurium decontamination factor (DF). Gas flowrate and $\mathrm{TeF}_{6}$ concentration showed only a slight effect on tellurium removal from the gas stream. In addition, the results showed that the required tellurium decontamination factor $(D F>700)$ for the removal of $\mathrm{TeF}_{6}$ from air streams can be readily achieved using activated alumina as a sorbant.

${ }^{23}$ Sorensen, H. and Fistedis, S., Hydrodynamics of a New Containment Concept by Energy Absorption, ANL-7214 (Dec 1966). 


\section{PUBLICATIONS}

Papers

Liquid-Vapor Phase Diagram and Thermodynamics of the SodiumBismuth System

A. K. Fischer, S. A. Johnson, and S: E. Wood

J. Phys. Chem. 71(5), 1465-1472 (April 1967)

Removal of Plutonium Hexafluoride from Cell Exhaust Air by Hydrolysis and Filtration

R. W. Kessie

Proc. 9th AEC Air Cleaning Conf., Boston, September 13-16, 1966, ed. J. M. Morgan and M. W. First. USAEC Report CONF-660904 (January 1967), Vol. 2, pp. 741-762

Direct Indication of Particle Size in Fluidized Bed

I. E. Knudsen and W. F. Olsen

Chem. Eng. 74(8), 244, 246 (April 10, 1967)

Tungsten Crucibles in Pyrochemical Processing of Nuclear Fuels

I. O. Winsch, M. L. Kyle, R. D. Pierce, and Leslie Burris

Nucl. Applications 3, 245-251 (April 1967)

Properties of Uranium Monoarsenide and Related Binary Systems

Yehuda Baskin

Bull. Am. Ceram. Soc. 46, 417 (April 1967). Abstract

A Design of a Flux Positioning Capsule for Use in the Vertical Thimbles of the CP- 5 Reactor

W. N. Beck

Intern. Symp. on Developments in Irradiation Capsule Technology, Pleasanton, California, May 3-5, 1966. USAEC Report CONF660511 , pp. 4.7.1-4.7.9 (1967)

The Uranium Monosulfide-Plutonium Monosulfide System

O. L. Kruger and J. B. Moser

Bull. Am. Ceram. Soc. $\underline{46}, 417$ (April 1967) Abstract

Fluid Resins for Mounting Metallographic Samples. Part I. Selection of Polyester Resins and Review of Chemical Reactions

O. L. Kruger

Praktische Metallographie 4, 125-138 (1967)

Compatibility of (U,Pu) Carbides with Iron- and Nickel-Base Alloys

Below $900^{\circ} \mathrm{C}$

T. W. Latimer

Bull. Am. Ceram. Soc. 46, 417 (April 1967) Abstract 
Evaporation of $\mathrm{PuO}_{2}$ from $1900^{\circ}$ to $2100^{\circ} \mathrm{K}$

D. R. Messier

Bull. Am. Ceram. Soc. 46, 421 (April 1967) Abstract

Thermal Conductivity and Heat Capacity of Plutonium Compounds

J: B. Moser and O. L. Kruger

Bull. Am. Ceram. Soc. 46, 421 (April 1967) Abstract

The Use of Thick Transducers to Generate Short-Duration Stress Pulses in Thin Specimens

R. G. Peterson and M. Rosen

J. Acoust. Soc. Am. 41, 336-345 (February 1967)

Comparison between Ultrasonic Inspection Systems--Mechanical Scan versus Television Imaging

R. H. Selner and H. Berger

Mater. Evaluation 25, 91-95 (April 1967)

A Third Generation of Breeder Reactors

T. R. Bump

Sci. Am. 216, 25-33 (May 1967)

Atmospheric Dispersion of Fission Products Including the Effects of Building Dilution and Radioactive Decay

Ira Charak

Nucl. Appl. 3, 283-286 (May 1967)

Material Limitations in the MHD Induction Generator

W. D. Jackson and E.S. Pierson

Electricity from MHD, Proc. Symp., Salzburg, July 4-8, 1966.

Intern. Atomic Energy Agency, Vienna, 1966, Vol. 2, pp. 889-902

End Losses in MHD Channels of Variable Cross Section and Their Reduction

J. R. Moszynski

Electricity from MHD, Proc. Symp., Salzburg, July 4-8, 1966.

Intern. Atomic Energy Agency, Vienna, 1966, Vol. 2, pp. 103 1-1040

MHD Generators Operating with Two-Phase Liquid Metal Flows

M. Petrick

Electricity from MHD, Proc. Symp., Salzburg, July 4-8, 1966.

Intern. Atomic Energy Agency, Vienna, 1966, Vol. 2, 889-902

Round Table Discussion on Liquid Metal Systems

M. Petrick, G. A. Brown, H. Billett, J. Pericart, R. D. Radebold, and

E. E. Shpilrain

Electricity from MHD, Proc. Symp., Salzburg, July 4-8, 1966.

Intern. Atomic Energy Agency, Vienna, 1966, Vol. 2, pp. 1141-1153 
The Design and Performance of a $1200^{\circ} \mathrm{F}$ Magnetic Flowmeter for In-Core Application in Sodium-Cooled.Reactors

G. F. Popper and M. C. Glass

Trans. IEEE NS-14(1), 342-347 (February 1967)

The Materials Selection Problem as Related to Thermocouples Used to Measure Nuclear Reactor Fuel Pin Temperatures up to $2800^{\circ} \mathrm{C}$

G. F. Popper and A. E. Knox

Trans. IEEE NS-14(1), 333-341 (February 1967)

Simulation of Reciprocating Gas Compressors with Automatic Reed Valves

M. W. Wambsganss, Donald Coates, and Raymond Cohen Simulation 8, 209-214 (April 1967)

Measurement of the $\mathrm{Li}^{6}$ ( $n$, absorption) and $\mathrm{B}^{10}$ ( $n$, absorption) Cross Sections by the Shell Transmission Method

S. A. Cox and F. R. Pontet

J. Nucl. Energy 21, 271-283 (March 1967)

$\underline{\text { ANL Reports }}$

ANL-6841 SAFETY ANALYSIS ASSOCIATED WITH THE PLUTONIUM RECYCLE EXPERIMENT IN EBWR

B. J. Toppe1, P. J. Vogelberger, Jr., and E. A. Wimunc

ANL-6994 ENGINEERING DEVELOPMENT OF FLUID-BED FLUORIDE VOLATILITY PROCESSES. Part 10. Bench-scale Studies on Irradiated, Highly Enriched, Uranium-alloy Fuels

A. A. Chilenskas, K. S. Turner, J. E. Kincinas, and

G. L. Potts

ANL-7183 FEASIBILITY STUDY OF NUCLEAR STEAM SUPPLY SYSTEM USING 10,000-MW, SODIUM-COOLED BREEDER REACTOR

K. A. Hub, I. Charak, D. E. Lutz, D. H. Thompson,

P. F. Gast, D. A. Meneley, and I. M. Keyfitz

ANL-7202 THE ELECTRICAL DESIGN OF THE EBR-II

F. Verber and H. L. Schmidt 
ANL-7277 TWO AXISYMMETRIC STEADY-STATE THERMO-

ELASTICITY PROBLEMS FOR TRANSVERSELY ISOTROPIC SOLIDS

Richard A. Valentin

ANL-7281 MEASURED PHYSICS PARAMETERS IN A ZONED FAST URANIUM CARBIDE CORE, ASSEMBLY $4 Z$

R. A. Karam, A. Ancarani, F.H. Helm, W. Y. Kato, G. W. Main, and G. K. Rusch 
